\begin{abstract}
KOHUT, SALINA MARVELLE. Avian Use of Suburban Greenways as Stopover Habitat. (Under the direction of George R. Hess and Christopher E. Moorman.)

The decline of Neotropical migrant songbirds has called attention to the need for habitat conservation along the entire migratory route, and scientists now recognize the need to conserve stopover habitat in addition to habitat on the breeding and wintering grounds. Greenways are a popular means for accomplishing conservation goals in suburban areas and might provide stopover habitat in urbanizing areas where habitat loss and alteration are accelerating.
\end{abstract}

My study examined the effects of greenway forested corridor width, greenway vegetative characteristics, and adjacent land cover on the species richness and abundance of migrant songbirds during spring and fall migration. I conducted the study to provide city planners with management recommendations for the construction and maintenance of greenways that will benefit migrating songbirds. During spring and fall migration, 2004, and spring migration, 2005, I surveyed birds in 47 segments of public greenway in Raleigh and Cary, North Carolina, USA representing a range of forested corridor widths and adjacent land covers. I also surveyed three reference sites along trails in William B. Umstead State Park, the largest contiguous forested area (2,201-hectares) nearest the study greenways.

Migrant species richness was higher in wider greenways in both spring and fall. During spring migration, migrant bird richness and abundance generally increased with tree height and percent hardwood tree composition, and abundance was greater in greenways with more shrub cover. During fall migration, migrants occurred most commonly in greenways with lower canopy cover and higher shrub cover. Although forest-interior migrant richness 
was not correlated with greenway forest corridor width in either season, they were more abundant in the reference sites than in the greenways during spring and fall. During spring, forest interior migrants were less common in greenways surrounded by more bare earth and pavement cover, both signs of intense development.

Though migrants used greenways of all widths, forested corridors wider than $150 \mathrm{~m}$ had the greatest overall diversity and abundance of migrants. Therefore, planners should conserve the widest greenway corridors possible. Shrub and ground cover should be retained within the greenway to provide the complex vegetative structure that migrants use. In urbanizing areas, planners can provide stopover habitat for forest-interior migrants by constructing greenways in areas of lower development intensity and by conserving larger parks or reserves in addition to greenways. 


\section{AVIAN USE OF SUBURBAN GREENWAYS AS STOPOVER HABITAT}

by

SALINA MARVELLE KOHUT

A thesis submitted to the Graduate Faculty of

North Carolina State University

In partial fulfillment of the

Requirements for the Degree of

Master of Science

\section{FISHERIES AND WILDLIFE SCIENCE}

Raleigh, North Carolina

2007

\section{APPROVED BY:}

George R. Hess

Co-chair of Advisory Committee
Christopher E. Moorman

Co-chair of Advisory Committee

Theodore R. Simons 


\section{BIOGRAPHY}

Salina Kohut (née Kovach) was born in Uniontown, PA in 1977, but grew up in Garner, NC. As a child, she was keenly interested in the avian world, and spent countless hours observing the feathered fauna of her backyard. She would even perform counts of the birds seen in her yard each morning before school. Salina attended Garner Senior High School where her exceptional science teachers fueled her interest in the natural world. Upon graduating in 1995, she attended the University of North Carolina at Chapel Hill as one of the recipients of the James M. Johnston Scholarship. An avian biology class rekindled Salina's interest in birds. Her involvement with the UNC Newman Catholic Student Center led to her meeting her future husband Matt Kohut. Salina earned a B.S. in Biology in 1999, graduating with distinction.

Following graduation, she pursued her interest in birds first by working as a summer field assistant studying grassland birds in Iowa and then as a waterfowl bander in Colorado. Salina completed an internship at the Florida Keys Wild Bird Rehabilitation Center, and then came to North Carolina State University to work with Woodlot Forestry Research and Development to help complete a natural resources survey of Camp Butner National Guard Training Site. She continued to work at Woodlot Forestry R\&D and worked with the Forest Nutrition Cooperative while beginning coursework towards her Master's degree.

Salina married Matthew Kohut in 2004. They have two cockatiels, Annabelle and Mr. Katie. Salina enjoys bird watching, hiking, backpacking, reading, and scrapbooking. She is involved in Young Adult Ministry at her church and volunteers at the Piedmont Wildlife Center rehabilitation hospital. 


\section{ACKNOWLEDGEMENTS}

I thank my committee chairmen George Hess and Christopher Moorman for giving me the opportunity to be a part of the Greenways for Wildlife initiative. I am grateful to them and to Ted Simons for their help in designing this study and for their advice as it evolved. I also greatly appreciate their patience as I have worked to complete this research. I thank Marcia Gumpertz for her statistical counsel and Nathan Tarr for his hard work during the first field season. Thank you to "The Woodlotians" of Woodlot Forestry R\&D, Carlisle Franklin, Dennis Hazel, Glenn Catts, Kathleen Summitt, Christine Wiecek, and Traci Matthews, for their support and encouragement, and I especially thank Dennis for his advice and Glenn for his GIS and remote sensing help. I am grateful to the City of Raleigh, the Town of Cary, and William B. Umstead State Park for allowing me to conduct research on their lands. This research would not have been possible without the generous funding and resources from the USDA Forest Service and the North Carolina State University Department of Forestry and Environmental Resources. I thank my parents for their love and prayers through the years, and my husband Matt for his love, patience, and understanding. 


\section{TABLE OF CONTENTS}

Page

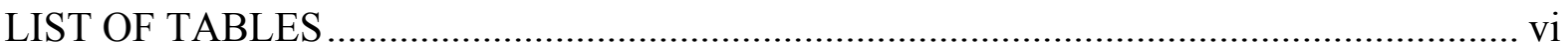

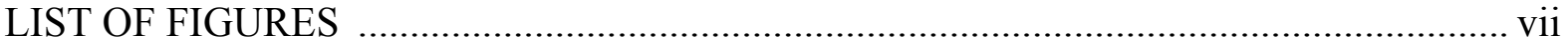

\section{CHAPTER 1: LITERATURE REVIEW}

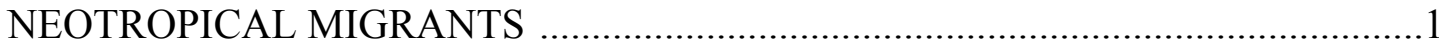

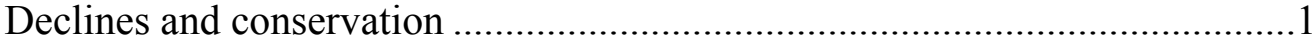

The importance of stopover habitat .......................................................2

Habitat selection en route.....................................................................4

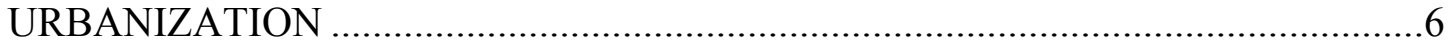

National and local trends ...............................................................6

The urban avian community ..............................................................

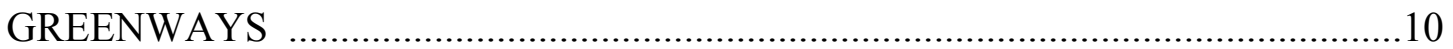

Greenways as a conservation strategy …............................................... 10

City of Raleigh and Town of Cary greenways.............................................11

Conclusion and further research ................................................................12

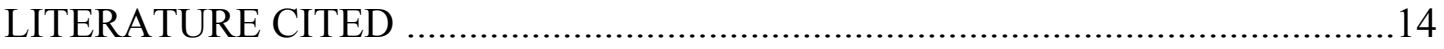

\section{CHAPTER 2: AVIAN USE OF SUBURBAN GREENWAYS AS STOPOVER}

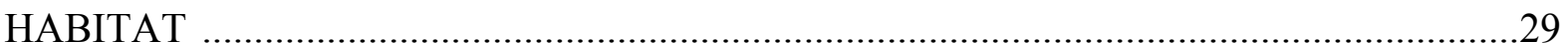

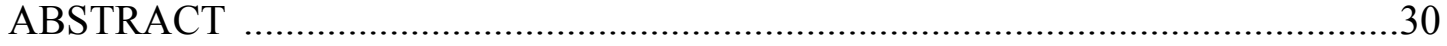

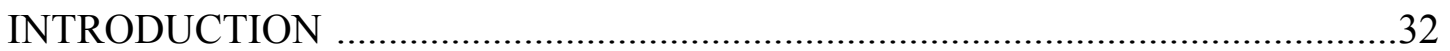

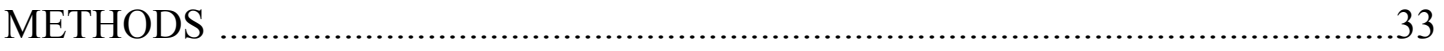

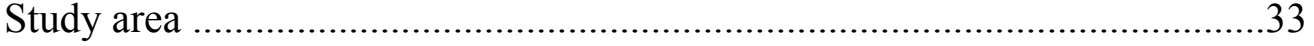

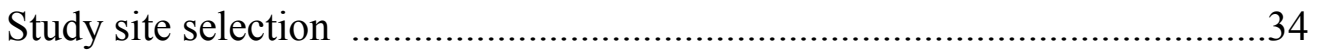

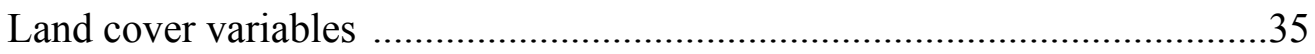




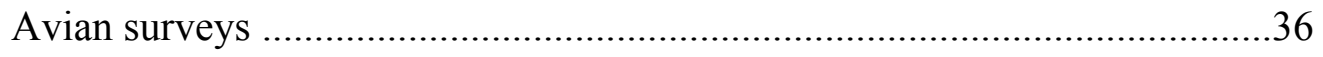

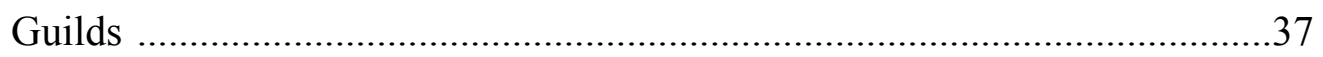

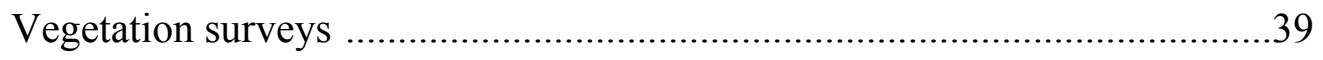

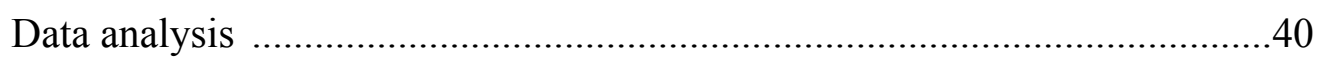

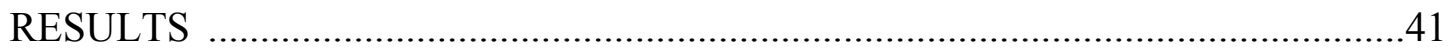

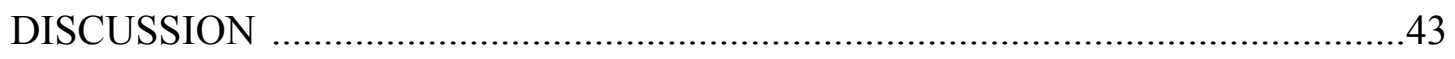

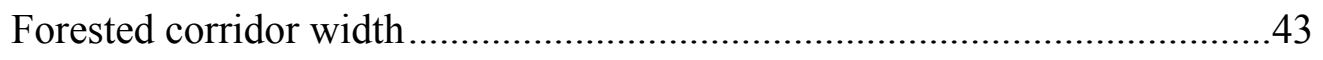

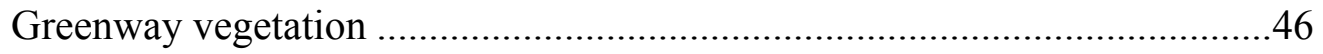

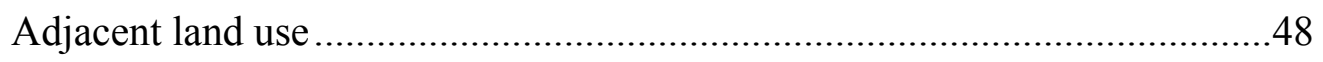

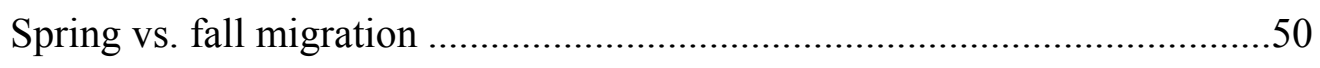

Design and management recommendations ..................................................50

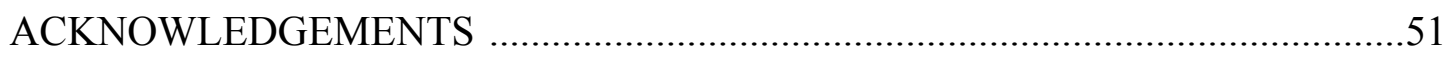

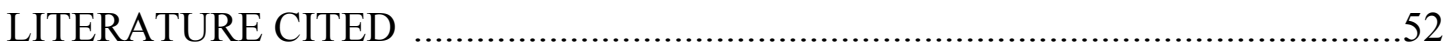

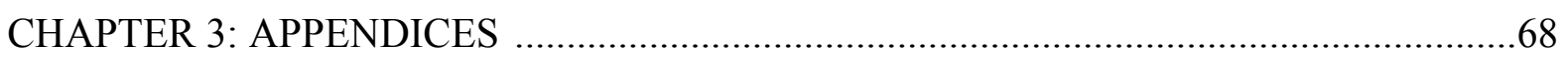

APPENDIX 1. Winter resident and year-round resident species occurrences in greenways and reference sites presented by adjacent land use and width categories..69 APPENDIX 2. Species recorded in each greenway segment and reference site during

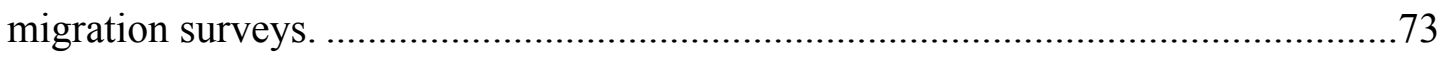

APPENDIX 3. End point coordinates of greenway and reference site transects in

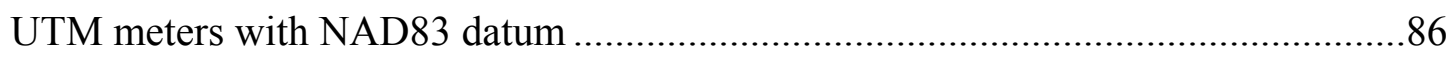




\section{LIST OF TABLES}

TABLE 1. Description of independent variables used in stepwise multiple regression analysis on guild species richness and abundance measures from Raleigh and Cary, NC greenways (2004-2005).

TABLE 2. Migrant bird species occurrences in greenways and reference sites presented by adjacent land use and width categories. Each cell contains the number of segments in the corresponding category in which the species was recorded during spring migration (S) (2004-2005) or fall migration (F) (2004). Adjacent land use categories are: LDR, lowdensity residential ( $\leq 7.5$ lots/hectare); HDR, high-density residential ( $>7.5$ lots/hectare); OFC, Office/Institutional. Reference segments are indicated by REF.

TABLE 3. Final regression models, reported with coefficients and partial F-statistic significance levels for included variables for greenways in Raleigh and Cary, NC during spring migration (2004-2005). Significance levels set at $\alpha=0.05$ for variable inclusion in models.

TABLE 4. Final regression models, reported with coefficients and partial F-statistic significance levels for included variables for greenways in Raleigh and Cary, NC during fall migration (2004). Significance levels set at $\alpha=0.05$ for variable inclusion in models...64 


\section{LIST OF FIGURES}

FIG. 1. Greenway segment and reference site locations in Raleigh and Cary, North Carolina, USA.

FIG. 2. Forested corridor width and adjacent land use were determined for each $200-\mathrm{m}$ greenway segment in ArcGIS.

FIG. 3. Mean richness and abundance of migrating birds using reference sites in Umstead State Park and Raleigh and Cary, NC greenways of differing forested corridor width categories during spring (2004-2005) and fall (2004) shown with standard deviation bars. ..67 


\section{CHAPTER 1: LITERATURE REVIEW NEOTROPICAL MIGRANTS}

\section{Declines and Conservation}

Nearctic-Neotropical migrant birds (hereafter "Neotropical migrants") breed in temperate North America but spend the winter in tropical latitudes (Petit 2000). Numerous studies have documented declines of Neotropical migrant songbirds on continental, regional, and local scales, especially in eastern North America (e.g. Graber and Graber 1963, Holmes and Sherry 1988, Robbins et al. 1989, Terborgh 1989, Askins et al. 1990, Sauer and Droege 1992, Hagan et al. 1992, Peterjohn et al. 1995, Ballard et al. 2003, Lloyd-Evans and Atwood 2004). The concern over these declines has prompted extensive investigation of the contributing factors and has spurred the development of conservation measures (e.g. Finch 1991, Hagan and Johnston 1992, Moore et al. 1993, Degraaf and Rappole 1995, Martin and Finch 1995, Moore 2000, Faaborg 2002). Habitat loss, degradation, and fragmentation on the breeding and wintering grounds are seen as complicit in the declines (Sherry and Holmes 1996, Petit 2000, Rappole et al. 2003, also see Robbins 1979, Whitcomb et al. 1981). Fragmentation of forests on the breeding grounds can result in increased levels of brood parasitism (e.g. Robinson et al. 1995, Arcese et al. 1996, but see Gustafson et al. 2001) and nest depredation (e.g. Wilcove 1985, Andrén 1992, Danielson et al. 1997, Heske et al. 1999, Chalfoun et al. 2002, Schmidt 2003 but see Lahti 2001). The spread of invasive, exotic vegetation reduces the cover of native plants to which the birds are adapted (Borgmann and 
Rodewald 2004). The use of pesticides also contributes to population declines (Gard et al. 1993, Gard et al. 1995).

More recently, however, researchers have focused on the conditions and events during migration that may contribute to songbird declines (Newton 2006) and have implicated the loss and fragmentation of stopover habitat (Petit 2000, Hutto 2000, Pearson and Simons 2002, Mehlman et al. 2005). Stopover habitats are those areas birds use during migration to rest and refuel between legs of their journey. The suitability of stopover habitat, especially in regards to food availability, can determine whether migration is successful, and ultimately determine breeding success (Newton 2006).

\section{The Importance of Stopover Habitat}

Migratory birds are extremely vulnerable during migration (Sillett and Holmes 2002), and migration is especially difficult for juveniles making their first migratory flight in the fall (Woodrey and Moore 1997, Yong et al. 1998, Jones et al. 2002). During this energetically demanding journey (Blem 1980), migrants face challenges such as finding food, water, and cover in unfamiliar areas (Moore et al. 1995). They must contend with inter- and intraspecific competition with other migrants and resident birds (see Kale 1967, Rappole and Warner 1976, Kodric-Brown and Brown 1978, Bibby and Green 1980, Moore and Yong 1991, Yong et al. 1998). Migrants encounter hazards such as variable or adverse weather (e.g. Wiedenfeld and Wiedenfeld 1995, Stokke et al. 2005, Marra et al. 2005) and predators (Aborn 1994, Lindström 1989, Cimprich et al. 2005). In addition, migrants may need to correct for orientation errors (Moore et al. 1995). All of this must be accomplished in a 
changing landscape (Heglund and Kagen 2005) with fluctuating resources (Schneider and Harrington 1981).

Consistently finding suitable stopover habitat is an important determinant of migratory success (Moore et al. 1995). Birds that arrive on the breeding grounds with remaining fat stores experience greater reproductive success than those that arrive spent (Smith and Moore 2003). Stopover may range from a few hours to several days (Moore et al. 1995) depending on the bird's energetic condition and on the suitability of the habitat it encounters (Morris 1996, Moore and Kerlinger 1987, Mehlman 2005). The quality of habitat adjacent to natural ecological barriers, such as large bodies of water and mountain ranges, is of particular concern because fueling before or after traversing such barriers is critical (e.g. Moore and Kerlinger 1987, Moore et al. 1990, Kuenzi et al.1991, Barrow et al. 2000). Moore et al. (1993) also recognized agricultural and urbanized areas as ecological barriers. As urbanized areas expand, they can create new barriers to migration. Mitigating habitat loss in areas of high population growth might prevent an urban area from becoming inhospitable to migrating songbirds.

Mehlman et al. (2005) described three functional types of stopover habitat: "fire escapes," "convenience stores," and "full-service hotels." The "fire escapes" are infrequently used, but can provide an emergency stopping place that can be the difference between death and continued migration. "Full-service hotel" locations are large areas of habitat that provide ample food, water, and shelter for many migrants (Mehlman et al. 2005). "Convenience store" stopover sites are small areas in an otherwise inhospitable matrix, such as an urbanized area, that allow migrants to rest briefly and replenish some fat stores in order to reach higher 
quality sites (Mehlman et al. 2005). Greenways, linear conservation corridors, are probably best described as "convenience store" sites. Greenways might also be an avenue for birds to navigate through urbanized areas during migration.

\section{Habitat Selection En Route}

The precise mechanisms by which birds choose habitats during migration are poorly understood (see Moore and Aborn 2000, Chernetsov 2006 for reviews); the selection of stopover habitat is complex and involves a bird's assessment of geographic, landscape, and habitat factors (Moore et al. 1993). In general, migrant birds select habitat during the early morning hours after nocturnal flight and then refine their habitat selection before settling in (Chernetsov 2006). They also may engage in "morning flight." The purposes of these short, low-altitude flights include continued migration (Bingman 1980), compensation for orientation errors due to wind, and habitat selection (Wiedner et al. 1992). Initial habitat choice is influenced by factors extrinsic to the habitat such as innate habitat preferences, functional morphology, and foraging strategies, after which habitat selection is guided by factors intrinsic to the habitat such as vegetation structure (see Chernestov 2006). Generally, more migrants are supported in areas with taller, more structurally diverse vegetation (e.g. Moore et al. 1990), though some research suggests the opposite (Petit 2000). Food availability, competition, and risk of predation also might factor into habitat selection (Moore et al. 1993, Petit 2000, Chernestov 2006).

In general, birds use a wider range of habitat types during migration than during the breeding season (Chernetsov 2006). The habitat that is used may differ between spring and 
fall migration (e.g. Weisbrod et al. 1993, Swanson et al. 2003). However, habitat most similar to the breeding or wintering habitat may be sought (Petit 2000). For example, Parnell (1969) determined that warblers select habitat that resembles their breeding habitat, and Somershoe and Chandler (2004) discovered that some forest-interior specialists that require large blocks of habitat during the breeding season used large hammocks more often during migration in coastal South Carolina. During spring migration along the Gulf coast, birds selected habitat disproportionate to its amount of occurrence (Moore et al. 1990).

Distribution across habitat types differs among species (e.g. Parnell 1969), and juveniles and adults of a species can differ in their use of habitat during migration (e.g. Dunn and Nol 1980, Woodrey and Moore 1997, Yong et al. 1998).

The size and distribution of habitat blocks, or "patchiness," can affect habitat suitability (Moore et al. 1993). The theory of island biogeography (MacArthur and Wilson 1967) prompted extensive research examining breeding bird use of isolated habitat patches. Yet, the relative value of small and large habitat patches for migrants is largely unknown (Petit 2000). Many migrant birds use large patches in the breeding season but can be found in smaller habitat patches during migration (e.g. Blake 1986). Several studies have observed migrant bird use of small, often isolated habitat patches, but the increased value of larger areas also has been demonstrated. Martin (1980) found that migrant species richness and abundance increased with increasing area of shelterbelts on the Great Plains. Blake (1986) noted that although large woodlots might have a greater richness of migrant species, small woodlots can be used by a variety of species. Graber and Graber (1983) intimated that small woodlots might not be sufficient in the absence of large forest blocks; migrants foraging in 
small, isolated woodlots in Illinois were unable to accumulate fat stores, but migrants foraging in areas with extensive forest cover were able to store fat. In South Carolina, although larger hammocks supported higher species richness and more individuals, the highest migrant densities were found in smaller hammocks (Somershoe and Chandler 2004). Petit (2000) suggested that corridors might allow migrants to move among isolated habitat blocks and find alternative stopover sites. However, there has been no study of the value of the connecting corridors as stopover habitat.

\section{URBANIZATION}

\section{National and local trends}

In the United States, the conversion of land, especially forest, to urban uses has accelerated in recent decades (Alig et al. 2003) resulting in habitat loss (e.g. Robinson et al. 2005) and species decline (Czech et al. 2000). Between 1980 and 2000, the United States population increased by $24 \%$ (US Census Bureau 2006) while the area of developed land grew by $34.1 \%$ during approximately the same time period (1982-1997) (US Department of Agriculture 2000). One area of increasing urban expansion and rapid population growth is the six-county Triangle Region of North Carolina. From 1950-1990, urban population in the Triangle tripled and urbanized land area increased ninefold (Triangle Land Conservancy 2003). Wake County, located in the Triangle Region, is the second most populated county in North Carolina (US Census Bureau 2006) and one of the fastest growing counties in the

nation (Wake County 2007a). In just twenty years (1980-2000), Wake County more than 
doubled its population (Wake County 2007b), and from 1990-2000, population density increased by nearly 50\% (US Census Bureau 2006). By 2013, the county's population is expected to surpass one million residents (Wake County 2007b). The infrastructure needed to support this population growth will undoubtedly arise where fields and forests now fill the landscape.

\section{The urban avian community}

Changes in the breeding bird community following land development are well known (e.g. Graber and Graber 1963, Batten 1972, Walcott 1974, Aldrich and Coffin 1980, Clergeau et al. 1998; see Chase and Walsh 2006 for review). While urban environs can support larger numbers of breeding birds than the surrounding natural areas (Walcott 1974, Gavareski 1976, Bessinger and Osborne 1982), species richness is lower and most individuals are non-migratory generalists and exotics (Graber and Graber 1963, Batten 1972, Emlen 1974, Walcott 1974, Aldrich and Coffin 1980, Melles et al. 2003).

Urban areas harbor fewer canopy-feeding forest insectivores and more ground foraging seed-eaters and omnivores, including rock pigeons (Columba livia), European starlings (Sturnus vulgaris), and house sparrows (Passer domesticus) (Emlen 1974, Walcott 1974, Bessinger and Osborne 1982, Chase and Walsh 2006), that adapt well to nesting on human structures (Lancaster and Rees 1979). Resident species also are favored over migratory species (Allen and O'Connor 2000). Native cavity nesters (Degraff and Wentworth 1986, Rottenborn 1999, Blewett and Marzluff 2005) and ground nesters (Melles et al. 2003, Mason et al. 2007) are lacking in urban areas. Urban development alters natural plant 
communities by replacing pre-urban vegetation with specimen plantings of exotic ornamentals, which are of little value to native bird species (Bessinger and Osborne 1982, Degraaf and Wentworth 1986, Mills et al. 1989) and in some cases have negative consequences for reproductive success (Borgmann and Rodewald 2004).

Urbanization's resulting habitat fragmentation, alteration, and loss affects migrating songbirds. If migrating individuals do not encounter suitable habitat, they might have to stop more often, slowing them down and preventing a timely arrival on the breeding ground. Reduction of habitat surrounding a geographic barrier may leave a migrant unable to acquire resources needed for survival. Some of the most critical areas for migrating songbirds, such as coastlines, also are areas of rapid population growth and development (Mehlman et al. 2005).

Identifying and conserving habitats that provide habitat suitable for migrating songbirds within developed landscapes can help mitigate some of the effects of urbanization. Few researchers have examined migrant bird habitat in urban areas. Rodewald and Matthews (2005) determined that migrants in an urbanizing Midwestern landscape were more abundant in mature uplands than in riparian habitat. However, the absence of Neotropical transients was not related to the amount of urban cover within a $1 \mathrm{~km}$ radius. Though Hostetler et al. (2005) found no significant change in the richness and abundance of migrating birds in a remnant natural area and in an adjacent city park during the two years following the construction of an apartment complex, detections of some individual migrant bird species, such as ovenbirds, declined during fall migration following construction. 
Not only does the elimination of habitat brought on by urbanization affect migrating birds, but the addition of structures such as buildings (Klem 1990), communication towers (Crawford and Engstrom 2001), windmills (Johnson et al. 2002), and power lines (Bevanger 1998) can confuse and kill migrating birds. In a 29-year study of a television tower in Florida, more than 44,000 dead birds representing 186 species were collected (Crawford and Engstrom 2001). Erickson et al. (2001 cited by Johnson 2002) estimated that 33,000 birds are killed annually by wind turbines in the US. Klem (1990) estimated between 97.6 and 975.6 million migrating birds die annually from window collisions.

Urban and suburban areas are not entirely unsuitable as habitat for native birds. Vegetation in urban areas, especially shrub and canopy layers, influences the diversity of birds found breeding there (Hooper et al. 1973, Mills et al. 1989) as does the spatial arrangement of the vegetation (Goldstein et al. 1986) both at local and landscape scales (Bolger et al. 1997, Melles et al. 2003). When urbanization is examined along a gradient of rural to urban, the greatest breeding bird diversity may be found in areas of moderate development (Aldrich and Coffin 1980, Blair 1999). For example, suburban development in desert climes can increase species diversity because plantings associated with neighborhoods increase the vegetative complexity (Vale and Vale 1976, Rosenberg et al. 1987, Mills et al. 1989, Germaine et al. 1998). However, this can be at the expense of the most developmentsensitive native bird species which disappear as the landscape becomes more urban (Aldrich and Coffin 1980, Blair 1999, Mason et al. 2007). 


\section{GREENWAYS}

\section{Greenways as a conservation strategy}

Greenways are multipurpose, linear, protected open spaces that link natural areas while providing recreation and transportation opportunities (Little 1990, Hay 1991, Searns 1995). The President's commission on Americans Outdoors (1987, referenced by Smith 1993) describes greenways as "fingers of green that reach out from and around and through communities all across America" to "connect parks and forests and scenic country sides, public and private, in recreation corridors for hiking, jogging, wildlife movement, horse, and bicycle riding." Greenways have become a popular means to mitigate the effect of habitat loss and fragmentation associated with urbanization (Hay 1991), especially because it usually is easier to acquire ribbons of land than large forest blocks in rapidly developing areas where land is expensive (Smith 1993). Often, greenways are built where development cannot take place such as in flood prone areas along streams (Little 1990).

Greenways can be constructed along natural or manmade features such as streams, sewer line right-of-ways, and old railroad beds (Little 1990, Hay 1991). The benefits of greenways range from aesthetic and cultural to educational and ecological. Increased connectivity of natural areas facilitates movement of plants and animals to maintain biodiversity (Searns 1995, Hay 1991), and vegetation improves air and water quality and mitigates flooding (Smith 1993). Many residents take pride in their neighborhood greenways and perceive them as an asset to their community and quality of life because they contribute to health and fitness through recreation, provide natural areas, and contribute to favorable 
land use patterns (Schafer et al. 2000). The benefits of greenways can go beyond those resulting from the setting aside of land. For example, the Swift Creek greenway trail in Cary, NC was constructed entirely from recycled materials (Town of Cary 2006).

Though greenways present an attractive integration of man and nature, they are not a panacea for conservation in urban areas. The value of conservation corridors such as greenways has been debated (see Simberloff and Cox 1987, Noss 1987, Simberloff et al. 1992, Hess 1994, Beier and Noss 1998). Some of the features of greenways that make them attractive can actually be detractors. The linear nature of greenways increases the amount of edge and exposes birds to negative "edge effects," such as increased nest depredation, and there is minimal interior habitat for area-sensitive species (Mason et al. 2007). The abundance of edge combined with the connectivity of corridors can allow exotic plants and animals to easily spread through the landscape (Simberloff et al. 1992, but see Damschen et al. 2006). The compatibility of recreation and conservation is questioned by some because the presence of human activity can affect the behavior of birds and predators in the landscape (Miller and Hobbs 2000). The presence of people on trails can affect the feeding behavior of birds (Burger and Gochfeld 1998), and this could be especially detrimental during migration when refueling is of utmost importance.

\section{City of Raleigh and Town of Cary Greenways}

The City of Raleigh's Capital Area Greenway began as a master's thesis (Flournoy 1972) and became a model for greenway systems in North Carolina and throughout the country (Little 1990). Raleigh's 54-mile, 3000-acre greenway system consists of 
"interconnected linear parks that form a City-wide open space network that allows for passive recreation while forwarding the City's environmental protection goals" (City of Raleigh 2006). The goals for Raleigh's greenways include preserving the natural character of the land while providing buffers for other land uses, preserving wildlife corridors, protecting water quality by conserving riparian buffers and managing storm water runoff, and providing multiple use trails for recreation and alternative transportation (City of Raleigh 2006). There are plans to develop additional greenways at a rate of at least 1 mile per year (City of Raleigh 2006). Many of the trails follow streams and sewer line right-of-ways. Town of Cary greenways total 11.08 miles, many of which are located in floodplains unsuitable for development (Town of Cary 2006). The Town of Cary identifies many of the same benefits of their greenways as Raleigh, including recreation opportunity and water quality enhancement, and stresses increased quality of life and property value (Town of Cary 2006).

\section{Conclusion and Further Research}

While the effects of urbanization on breeding birds have been explored extensively, there has been little research on how the conversion and alteration of habitat resulting from urbanization affects migrating songbirds (but see Hostetler 2005). The expansion of urbanized land, coupled with the expansion of greenway systems in some communities, positions greenways as a possible medium for accomplishing migrant conservation goals in urban areas. Previous research in Raleigh and Cary greenways revealed that breeding development-sensitive birds were most abundant in wide greenways that contained narrow recreational trails (Mason et al. 2007). 
Because migrants often choose stopover habitat that is similar to their breeding habitat, it is possible that the recommendations for Neotropical migrant species on their breeding grounds also may benefit them during migration. There is little research on migrant use of stopover habitat in suburbanizing areas (but see Rodewald and Matthews 2005, Sodhi et al. 1999), and no research specifically examines the value of greenways as stopover habitat. Determining the characteristics of greenways that translate into suitable stopover habitat will provide planners with information needed to design greenways that are favorable to songbirds during migration. 


\section{LITERATURE CITED}

Aborn, D. A. 1994. Correlation between raptor and songbird numbers at a migratory stopover site. Wilson Bulletin 106:150-154.

Aldrich, J.W. and R. W. Coffin 1980. Breeding bird populations from forest to suburbia after 37 years. American Birds 34:3-7.

Alig, R. J., J. D. Kline, and M. Lichtenstein. 2004. Urbanization on the US landscape: looking ahead in the 21st century. Landscape and Urban Planning 69:219-234.

Allen, A. P. and R. J. O'Connor. 2000. Hierarchical correlates of bird assemblage structure on Northeastern U.S.A. lakes. Environmental Monitoring and Assessment 62:15-37.

Andrén, H. 1992. Corvid density and nest predation in relation to forest fragmentation: a landscape perspective. Ecology 73:794-804.

Arcese, P., J. N. M. Smith, and M. I. Hatch. 1996. Nest predation by cowbirds and its consequences for passerine demography. Proceedings of the National Academy of Sciences of the United States of America 93:4608-4611.

Askins, R. A., J. F. Lynch, and R. Greenberg. 1990. Population declines in migratory birds in eastern North America. Current Ornithology 7:1-57.

Ballard, G., G. R. Guepel, N. Nur, and T. Gardali. 2003. Long-term declines and decadal patterns in population trends of songbirds in Western North America, 1979-1999. Condor 105:737-755.

Barrow, W. C. Jr., C. Chen, R. B. Hamilton, K. Ouchley, and T. J. Spengler. 2000. Disruption and restoration of en route habitat, a case study: the Chenier Plain. Studies in Avian Biology 20:71-87. 
Batten, L. A. 1972. Breeding bird species diversity in relation to increasing urbanisation. Bird Study 19:157-166.

Beier, P. and R. F. Noss. 1998. Do habitat corridors provide connectivity? Conservation Biology 12:1241-1252.

Bessinger, S. R. and D.R. Osborne. 1982. Effects of urbanization on avian community organization. Condor 84:75-83.

Bevanger, K. 1998. Biological and conservation aspects of bird mortality caused by electricity power lines: a review. Biological Conservation 86:67-76.

Bibby, C. J. and R. E. Green. 1980. Foraging behavior of migrant Pied Flycatchers, Ficedula hypoleuca, on temporary territories. Journal of Animal Ecology 49:507-521.

Bingman, V. P. 1980. Inland morning flight behavior of nocturnal passerine migrants in eastern New York. Auk 97:465-472.

Blair, R. B. 1999. Birds and butterflies along an urban gradient: surrogate taxa for assessing biodiversity? Ecological Applications 9:164-170.

Blake, J.G. 1986. Species area relationships of migrants in isolated woodlots in East Central Illinois. Wilson Bulletin 98:291-296.

Blem, C. 1980. The energetics of migration. Pages 175-224 in Animal migration orientation and navigation (S. A. Gauthreaux, Ed.). Academic Press, New York, USA.

Blewett, C. M. and J. M. Marzluff. 2005. Effects of urban sprawl on snags and the abundance and productivity of cavity-nesting birds. Condor 107:678-693.

Bolger, D. T., T. A. Scott, and J. T. Rottenberry 1997. Breeding bird abundance in an 
urbanizing landscape in coastal Southern California. Conservation Biology 11:406420.

Borgmann, K. L. and A. D. Rodewald. 2004. Nest predation in an urbanizing landscape: the role of exotic shrubs. Ecological Applications 14:1757-1765.

Burger, J. and M. Gochfeld. 1998. Effects of ecotourists on bird behaviour at Loxahatchee National Wildlife Refuge. Environmental Conservation 25:13-21.

Chalfoun, A. D., F. R. Thompson, and M. J. Ratnaswamy. 2002. Nest predators and fragmentation: a review and meta-analysis. Conservation Biology 16:306-318.

Chase, J. F. and J. J. Walsh. 2006. Urban effects on native avifauna: a review. Landscape and Urban Planning 74: 46-69.

Chernetsov, N. 2006. Habitat selection by nocturnal passerine migrants en route: mechanisms and results. Journal of Ornithology 147:185-191.

Cimprich, D. A., M.S. Woodrey, and F.R. Moore. 2005. Passerine migrants respond to variation in predation risk during stopover. Animal Behaviour 69:1173-1179.

City of Raleigh. 2006. http://raleighnc.gov (accessed 1 August 2006).

Clergeau, P., J. L. Savard, G. Mennechez, and G. Falardeau. 1998. Bird abundance and diversity along an urban-rural gradient: a comparative study between two cities on different continents. Condor 100:413-425.

Crawford, R. L. and R. T. Engstrom. 2001. Characteristics of avian mortality at a North Florida television tower: a 29-year study. Journal of Field Ornithology 72:380-388.

Czech, B., P. R. Krausman, and P. K. Devers. 2000. Economic associations among causes of species endangerment in the United States. BioScience 50:593-601. 
Damschen, E. I., N. M. Haddad, J. L, Orrock, J. J. Tewksbury, and D. J. Levey. 2006. Corridors increase plant species richness at large scales. Science 313: 1284-1286.

Danielson, W.R., R. M. DeGraaf, and T. K. Fuller. 1997. Rural and suburban forest edges: effect on egg predators and nest predation rates. Landscape and Urban Planning 38:25-36.

Degraaf, R. M. and J. M. Wentworth. 1986. Avian guild structure and habitat associations in suburban bird communities. Urban Ecology 9:399-412.

Degraaf, R.M. and J. H. Rappole. 1995. Neotropical migratory birds: natural history, distribution, and population change. Cornell University Press, Ithaca, New York, USA.

Dunn, E. H. and E. Nol. 1980. Age-related migratory behavior of warblers. Journal of Field Ornithology 51:254-269.

Emlen, J. T. 1974. An urban bird community in Tucson, Arizona: derivation, structure, regulation. Condor 76:184-197.

Faaborg, J. 2002. Saving migrant birds: developing strategies for the future. University of Texas Press, Austin, Texas, USA

Finch, D. M. 1991. Population ecology, habitat requirements, and conservation of Neotropical migratory birds. General Technical Report RM-205, USDA Forest Service, Rocky Mountain Forest and Range Experiment Station, Ft. Collins, Colorado, USA.

Flournoy, W. L. Jr. 1972. Capital city greenway: a report to the city council on the benefits, potential, and methodology of establishing a greenway system in Raleigh. Raleigh, 
North Carolina, USA.

Gard, N.W., M. J. Hooper, and R.S. Bennett. 1993. Effects of pesticides and contaminants on Neotropical migrants. Pages 310-314 in Status and Management of Neotropical Migratory Birds. (D. M. Finch and P.W. Stangel, Eds.). US Fish and Wildlife Service General Technical Report RM-229, Rocky Mountain Forest and Range Experiment Station, Fort Collins, Colorado, USA.

Gard, N. W., M. J. Hooper, and R. S. Bennett. 1995. An assessment of potential hazards of pesticides and environmental contaminants. Pages 294-310 in Ecology and management of Neotropical migratory birds: a synthesis and review of critical issues (T. E. Martin and D. M. Finch, Eds.), Oxford University Press, Oxford.

Germaine, S. S., S. S. Rosenstock, R. E. Schweinsburg, and W. S. Richardson. 1998. Relationships among breeding birds, habitat, and residential development in Greater Tucson, Arizona. Ecological Applications 8:680-691.

Goldstein, E. L., M. Gross, M., R. M. DeGraaf. 1986. Breeding birds and vegetation: a quantitative assessment. Urban Ecology 9:377-385.

Graber, R. R. and J. W. Graber. 1963. A comparative study of bird populations in Illinois, 1906-1909 and 1956-1958. Illinois Natural History Survey Bulletin 28:383-528.

Graber, J. W., and R. R. Graber. 1983. Feeding rates of warblers in spring. Condor 85:139 150. Gustafson, E.J., M. G. Knutson, G. J. Niemi. 2002. Evaluation of spatial models to predict vulnerability of forest birds to brood parasitism by cowbirds. Ecological Applications 12:412-426.

Hagan, J. M., T. L. Lloyd-Evans, J. L. Atwood, and D. S. Wood. 1992. Long-term changes in 
migratory landbirds in the northeastern United States: evidence from migration capture data. Pages 115-130 in Ecology and conservation of Neotropical migrant landbirds (J. M. Hagan, III, and D. W. Johnston, Eds.). Smithsonian Institution, Washington, D.C., USA.

Hagan, J.M. III and D.W. Johnston 1992. Ecology and conservation of Neotropical migratory landbirds. Smithsonian Institution Press, Washington, D.C., USA.

Hay, K. G. 1991. Greenways and biodiversity. Pages 162-175 in Landscape linkages and biodiversity (W. E. Hudson, Ed.). Island Press, Washington, D.C., USA.

Hegluind, P. J. and S. K. Skagen. 2005. Ecology and physiology of en route Nearctic Neotropical migratory birds: a call for collaboration. Condor 107:193-196.

Heske, E. J., S.K. Robinson, and J. D. Brawn. 1999. Predator activity and predation on songbird nests on forest-field edges in east-central Illinois. Landscape Ecology $14: 345-354$

Hess, G.R. 1994. Conservation corridors and contagious disease- a cautionary note. Conservation Biology 8:256-263.

Holmes, R. T. and T. W. Sherry. 1988. Assessing population trends of New Hampshire forest birds: local vs. regional patterns. Auk 105:756-768.

Hooper, R. G., H. S. Crawford, and R. F. Harlow. 1973. Bird Density and diversity as related to vegetation in forest recreation areas. Journal of Forestry 71:766-769.

Hostetler, M., S. Duncan, and J. Paul. 2005. Post-construction effects of an urban development on migration, resident, and wintering birds. Southeastern Naturalist $4: 421-434$ 
Hutto, R. L. 2000. The importance of en route periods to the conservation of migratory landbirds. Studies in Avian Biology 20:109-114.

Johnson, G. D., W. P. Erickson, M. D. Strickland, M. F. Shepherd, D. A. Shepherd, and S. A. Sarappo. 2002. Collision mortality of local and migrant birds at a large-scale wind power development on Buffalo Ridge, Minnesota. Wildlife Society Bulletin 30:879887.

Jones, J., C. M. Francis, M. Drew, S. Fuller, and M. W. S. Ng. 2002. Age-related differences in body mass and rates of mass gain of passerines during autumn migratory stopover. Condor 104:49-58.

Kale, H. W. 1967. Aggressive behavior by a migrating Cape May Warbler. Auk 84:120-121.

Klem, D. Jr. 1990. Collisions between birds and windows: mortality and prevention. Journal of Field Ornithology 6:120-128.

Kodric-Brown, A. and J. H. Brown. 1978. Influence of economics, interspecific competition, and sexual dimorphism on territoriality of migrant Rufous Hummingbirds. Ecology $59: 285-296$.

Kuenzi, A. J., F. R. Moore, and T. R. Simons. 1991. Stopover of Neotropical landbird migrants on East Ship island following trans-gulf migration. Condor 93:869-883.

Lahti, D.C. The "edge effect on nest predation" hypothesis after twenty years. Biological Conservation 99:365-374.

Lancaster, R. K. and W. E. Rees. 1979. Bird communities and the structure of urban habitats. Canadian Journal of Zoology 57:2358-2368.

Lindström, Å. 1989. Finch flock size and risk of hawk predation at a migratory stopover site. 
Auk 106:225-232.

Little, C. E. 1990. Greenways for America. The Johns Hopkins University Press, Baltimore, Maryland, USA.

Lloyd-Evans, T. L. and J. L. Atwood. 2004. 32 years of changes in passerine numbers during spring and fall migrations in coastal Massachusetts. Wilson Bulletin 116:1-16.

Lynch, J. F., and D. F. Whigham. 1984. Effects of forest fragmentation on breeding bird communities in Maryland, USA. Biological Conservation 28:287-324.

MacArthur, R. H., and E.O. Wilson 1967. The theory of island biogeography. Princeton University Press, Princeton, New Jersey, USA.

Martin, T. E. 1980. Diversity and abundance of spring migratory birds using habitat islands in the great plains. Condor 82:430-439.

Martin, T. E., and D. M. Finch. 1995. Ecology and management of Neotropical migratory birds: a synthesis and review of critical issues. Oxford University Press, New York, USA.

Mason, J. H., C. E. Moorman, G. R. Hess, and K. E. Sinclair. 2007. Designing suburban greenways to provide habitat for forest-breeding birds. Landscape and Urban Planning 80:153-164.

Mehlman, D.W., S. E. Mabey, D. N. Ewert, C. Duncan, B. Abel, D. Cimprich, R. D. Sutter, and M. Woodrey. 2005. Conserving stopover sites for forest-dwelling migratory landbirds. Auk 122:1281-1290.

Melles, S., S. Glenn, and K. Martin. 2003. Urban bird diversity and landscape complexity: 
species-environment associations along a multiscale habitat gradient. Conservation Ecology 7(1):5. [online] http://www.consecol.org/vol7/iss1/art5 (accessed 4 January 2004).

Miller, J. R. and N. T. Hobbs. 2000. Recreational trails, human activity, and nest predation in lowland riparian areas. Landscape and Urban Planning 50:227-236.

Mills, G. S., J. B. Dunning, and J. M. Bates. 1989. Effects of urbanization on breeding bird community structure in southwestern desert habitats. Condor 91:416-428.

Moore, F. R. 2000. Stopover ecology of Nearctic-Neotropical landbird migrants: habitat relations and conservation implications. Studies in Avian Biology 20.

Moore, F. R. and P. Kerlinger. 1987. Stopover and fat deposition by North American wood warblers (Parulinae) following spring migration over the Gulf of Mexico. Oecologia $74: 47-54$

Moore, F. R. and W. Yong. 1991. Intercontinental-bird migrants compete for food resources during stopover. Behavioral Ecology and Sociobiology 28:85-90.

Moore, F. R., P. Kerlinger, and T. R. Simons. 1990. Stopover on a Gulf coast barrier island by spring trans-Gulf migrants. Wilson Bulletin 102:487-500.

Moore, F. R., S. A. Gauthreaux, Jr., P. Kerlinger, and T. R. Simons. 1995. Habitat requirements during migration: important link in conservation. Pages 121-144 in Ecology and management of Neotropical migratory birds: a synthesis and review of critical issues (T. E. Martin and D. M. Finch, Eds.). Oxford University Press, New York, USA.

Moore, F. R., S. A. Gauthreaux, P. Kerlinger, and T. R. Simons. 1993. Stopover habitat: 
management implications and guidelines. Pages 58-69 in Status and management of Neotropical migratory birds. (D. M. Finch and P. W. Stangel, Eds.). General Technical Report RM-229. USDA Forest Service, Rocky Mountain Research Station, Fort Collins, Colorado, USA.

Moore, F. R. and D. A. Aborn. 2000. Mechanisms of en route habitat selection: how do migrants make habitat decisions during stopover? Studies in Avian Biology 20:34-42.

Morris, S. R. 1996. Mass loss and the probability of stopover by migrant warblers during spring and fall migration. Journal of Field Ornithology 67:456-462.

Newton, I. 2006. Can conditions experienced during migration limit the population levels of birds? Journal of Ornithology 147:146-166.

Noss, R. F. 1987. Corridors in real landscapes: a reply to Simberloff and Cox. Conservation Biology 1:159-164.

Parnell, J. F. 1969. Habitat relations of the Parulidae during spring migration. Auk 86:505521.

Pearson, S. M. and T. R. Simons. 2002. Spatial analysis of stopover habitats of Neotropical migrant birds. Chapter 52 in Predicting species occurrences: issues of accuracy and scale (J. M. Scott, P. J. Heglund, and M. L. Morrison, Eds.). Island Press, Covelo, California, USA.

Peterjohn, B. G., J. R. Sauer, and C. S. Robbins. 1995. Population trends from the North American breeding-bird survey. Pages 3-39 in Ecology and management of Neotropical migratory birds (T E. Martin and D. M. Finch Eds.). Oxford University Press, Oxford. 
Petit, D. R. 2000. Habitat use by landbirds along Nearctic-Neotropical migration routes: implications for conservation of stopover habitats. Studies in Avian Biology 20:1533.

Rappole, J. H. and D. W. Warner. 1976. Relationships between behavior, physiology, and weather in avian transients at a migration stopover site. Oecologia 26:193-212.

Rappole, J. H., D. I. King, and J. Diez. 2003. Winter vs. breeding-habitat limitation for an endangered avian migrant. Ecological Applications 13:735-742.

Robbins, C.S. 1979. Effects of forest fragmentation on bird populations. Pages 198-213 in Management of north central and north east forests for nongame birds. General Technical Report NC-51, USDA Forest Service, North Central Forest Experiment Station, St. Paul, Minnesota, USA.

Robbins, C. S., J. R. Sauer, R. S. Greenberg, and S. Droege. 1989. Population declines in North American birds that migrate to the Neotropics. Proceedings of the National Academy of Sciences USA 86:7658-7662.

Robinson, S. K., F. R. Thompson III, T. M. Donovan, D. R. Whitehead, and J. Faaborg. 1995. Regional forest fragmentation and the nesting success of migratory birds. Science 267:1987-1990.

Robinson, L., J. P. Newell, and J. M. Marzluff. 2005. Twenty-five years of sprawl in the Seattle region: growth management responses and implications for conservation. Landscape and Urban Planning 71:51-72.

Rodewald, P. G. and M. C. Brittingham. 2004. Stopover habitats of landbirds during fall: use of edge-dominated and early-successional forests. Auk 121:1040-1055. 
Rodewald, P. G. and S. N. Matthews. 2005. Landbird use of riparian and upland forest stopover habitats in an urban landscape. Condor 107:259-268.

Rosenberg, K. V., S. B. Terrill and G. H. Rosenberg. 1987. Value of suburban habitats to desert riparian birds. Wilson Bulletin 99:642-654.

Rottenborn, S.C. 1999. Predicting the impacts of urbanization on riparian bird communities. Biological Conservation 88:289-299.

Sauer, J. R. and S. Droege 1992. Geographic patterns in population trends of Neotropical migrants in North America. Pages 26-42 in Ecology and conservation of Neotropical migrant landbirds. (J. M. Hagan III and D. W. Johnson, Eds.). Smithsonian Institution Press, Washington, D.C., USA.

Schafer, C. S., B. K. Lee, and S. Turner. 2000. A tale of three greenway trails: user perceptions related to quality of life. Landscape and Urban Planning 49:163-178.

Schmidt, K. A. 2002. Nest predation and population declines in Illinois songbirds: a case for mesopredator effects. Conservation Biology 17:1141-1150.

Schneider, D. C. and B. A. Harrington. 1981. Timing of shorebird migration in relation to prey depletion. Auk 98:801-811.

Searns, R. M. 1995. The evolution of greenways as an adaptive urban landscape form. Landscape and Urban Planning 33:65-80.

Sherry, T. W., and R. T. Holmes. 1996. Winter habitat quality, population limitation, and conservation of Neotropical-Nearctic migrant birds. Ecology 77:36-48.

Sillett, T. S. and R. T. Holmes. 2002. Variation in survivorship of a migratory songbird through its annual cycle. Ecology 71:296-308. 
Simberloff, D. and J. Cox 1987. Consequences and costs of conservation corridors. Conservation Biology 1:63-71.

Simberloff, D., J. A. Farr, J. Cox, and D. W. Mehlman. 1992. Movement corridors: conservation bargains or poor investments. Conservation Biology 6:493-504.

Smith, D. S. 1993. An overview of greenways. Pages 1-22 in Ecology of greenways: design and function of linear conservation areas (D. S. Smith and P. C. Hellmund, Eds.). University of Minnesota Press, Minneapolis, USA.

Smith, R. J. and F. R. Moore. 2003. Arrival fat and reproductive performance in a long distance passerine migrant. Oecologia 134:325-331.

Sodhi, N. S., C. Briffett, L. Kong, and B. Yuen. 1999. Bird use of linear areas of a tropical city: implications for park connector design and management. Landscape and Urban Planning 45:123-130.

Stokke, B. G., A. P. Møller, B. Sæther, G. Rheinwald, and H. Gutscher. 2005. Weather in the breeding area and during migration affects the demography of a small long-distance passerine migrant. Auk 122:637-647.

Swanson, D. L., Carlisle, H. A., and E. T. Liknes. 2003. Abundance and richness of Neotropical migrants during stopover at farmstead woodlots and associated habitats in southeastern South Dakota. American Midland Naturalist 149:176-191.

Terborgh, J. 1989. Where have all the birds gone? Princeton University Press, Princeton, New Jersey, USA.

Town of Cary. 2006. Town of Cary Greenways and Trails. 
http://townofcary.org/depts/prdept/greenway/gwyhome.htm (accessed 1 August 2006).

Triangle Land Conservancy. 2003. State of open space 2002: the status of the Triangle's green infrastructure. Raleigh, North Carolina, USA.

U.S. Department of Agriculture. 2000. Summary Report: 1997 National Resources Inventory (revised December 2000), Natural Resources Conservation Service, Washington, D.C., and Statistical Laboratory, Iowa State University, Ames, Iowa, USA.

US Census Bureau. 2006. www.census.gov (Accessed 1 August 2006).

Vale, T. R. and G. R. Vale. 1976. Suburban bird populations in west-central California. Journal of Biogeography 3:157-165.

Wake County. 2007a. Census and population. www.wakegov.com/planning/census/default.htm (accessed 3 April 2007).

Wake County. 2007b. Population. http://www.wakegov.com/planning/demographic/ dd_Population.htm (accessed 3 April 2007).

Walcott, C. F. 1974. Changes in bird life in Cambridge, Massachusetts from 1860-1964. Auk 91:151-160.

Whitcomb, R. F., C. S. Robbins, J. F. Lynch, B. L. Whitcomb, M. K. Klimkiewicz, and D. Bystrak. 1981. Effects of forest fragmentation on avifauna of the eastern deciduous forest. Pages 125-205 in Forest island dynamics in man dominated landscapes (R. L. Burgess and D. M. Sharp, Eds.). Springer-Verlag, New York, USA.

Wiedenfeld, D. A. and M. G. Wiedenfeld. 1995. Large kill of Neotropical migrants by tornado and storm in Louisiana, April 1993. Journal of Field Ornithology 66:70-80. 
Wiedner, D. S., P. Kerlinger, D. A. Sibley, P. Holt, J. Hough, and R. Crossley. 1992. Visible morning flight of Neotropical landbird migrants at Cape May, New Jersey. Auk 109:500-510.

Wilcove, D. S. 1985. Nest predation in forest tracts and the decline of migratory songbirds. Ecology 66:1211-1214.

Winker, K., D. W. Warner, and A. R. Weisbrod. 1991. Unprecedented stopover site fidelity in a Tennessee Warbler. Wilson Bulletin 103:514-516.

Woodrey, M. S. and F. R. Moore. 1997. Age-related differences in the stopover of fall landbird migrants on the coast of Alabama. Auk 114:695-707.

Yong, W., D. M. Finch, F. R. Moore, and J. E. Kelly. 1998. Stopover ecology and habitat use of migratory Wilson's Warblers. Auk 115:829-842. 
CHAPTER 2

\section{AVIAN USE OF SUBURBAN GREENWAYS AS STOPOVER HABITAT}

\section{SALINA M. KOHUT ${ }^{1,2,3}$, GEORGE R. HESS ${ }^{1}$, AND CHRISTOPHER E. MOORMAN $^{1}$}

\footnotetext{
${ }^{1}$ Department of Forestry and Environmental Resources, North Carolina State University, Box 8008 Raleigh, NC 27695, USA

${ }^{2}$ Current address: 107 Paladin Place, Cary, NC 27513

3 Corresponding author; e-mail: salinakohut@myway.com
} 
ABSTRACT.--- Greenways are a popular means for accomplishing conservation goals in suburban areas, and if properly designed, they may provide avian stopover habitat in an otherwise inhospitable landscape. We examined the effect of greenway forested corridor width, vegetation composition and structure, and adjacent land cover on the species richness and abundance of migrating songbirds. During spring and fall migration, 2004, and spring migration, 2005, we surveyed birds in 47 segments of public greenway in Raleigh and Cary, North Carolina, USA representing a range of forested corridor widths and adjacent land covers. We also surveyed three reference sites along trails in William B. Umstead State Park, the largest contiguous forested area (2,201-hectares) nearest the study greenways.

Migrant species richness was higher in wider greenways in both spring and fall. During spring migration, migrant bird richness and abundance generally increased with tree height and percent hardwood composition, and abundance increased in greenways with more shrub cover. During fall migration, migrants occurred most commonly in greenways with lower canopy cover and higher shrub cover. Forest-interior migrant richness was not correlated with greenway forest corridor width in either season, but these species were more common in greenways surrounded by less bare earth and pavement cover in the spring. During both seasons, forest-interior species were more abundant in the reference sites than in the greenways.

Though migrants used greenways of all widths, in order to serve the greatest diversity of migrants, planners should conserve the widest greenway corridors possible. Forested corridors wider than $150 \mathrm{~m}$ had the greatest diversity and abundance of migrants, especially forest-edge species. Removing shrub and ground cover within the greenway should be 
avoided to maintain vegetative complexity. In urbanizing areas, planners can provide habitat for the greatest diversity of migrants by constructing greenways in areas of lower development intensity and by designing greenways in conjunction with larger parks or reserves. 
In the United States, the conversion of forest land to urban uses has accelerated in recent decades (Alig et al. 2004), and the resulting fragmentation, degradation, and alteration of habitat are major concerns for biological conservation. Of particular concern are migratory bird species, especially those that migrate to the Neotropics (hereafter "Neotropical migrants"). The widely documented declines in migratory songbird populations (e.g. Graber and Graber 1963, Robbins et al. 1989, Askins et al. 1990, Hagan et al. 1992) prompted extensive investigation of the contributing factors. Initially, the availability and condition of breeding and wintering habitat attracted the most attention. Researchers recently have focused on the conditions and events during migration that might contribute to migrant songbird declines (Newton 2006). Effective conservation measures must include all life history phases including migration (Hagan and Johnston 1992, Moore et al. 1993, Moore 2000, Faaborg 2002).

Neotropical migrants are vulnerable during migration, perhaps more so than during any other time of the year (Sillett and Holmes 2002). During this energetically demanding time (Blem 1980), migrants must find suitable stopover habitat in which to replenish fat stores and rest while avoiding predation (Moore et al. 1995). The condition and availability of stopover habitat can have profound consequences for avian survival. However, the precise mechanisms by which birds choose habitats during migration and the specific habitat requirements for species are poorly understood (see Moore and Aborn 2000, Chernetsov 2006 for reviews).

Although it might be critical to migrating birds, the value of natural areas as stopover habitat in rapidly urbanizing landscapes is virtually unknown (Hostetler et al. 2005). 
Breeding birds have been the primary focus of urban bird studies (e.g. Emlen 1974, Bessinger and Osborne 1982, Friesen et al. 1995, Mason et al. 2007). Only recently have researchers begun examining stopover habitat in urban areas (Hostetler 2005, Rodewald and Matthews 2005.)

As multipurpose, linear, protected open spaces, greenways link natural areas while providing recreation opportunities and alternative transportation (Little 1990, Hay 1991, Searns 1995). Greenways have become a popular means to mitigate the effects of habitat loss and fragmentation associated with urbanization (Hay 1991). If properly designed greenways can serve as stopover habitat, they might be a cost effective means of providing this habitat in rapidly developing areas where land is expensive. However, there have been no studies of the value of greenways as stopover habitat.

We studied migrating songbirds in greenways to: 1) determine the influence of greenway forested corridor width and adjacent land cover on migrating bird abundance and species richness, and 2) provide recommendations to urban planners for the design of greenways as migratory bird stopover habitat.

\section{METHODS}

Study area.--- We studied migrating bird use of greenways in Raleigh and Cary, Wake County, North Carolina, USA, located in the Central Appalachian Piedmont. In recent decades, the region, known as the Triangle, has experienced rapid population growth and suburban development (Wake County 2002). From 1950-1990, urban population in the Triangle tripled and urbanized land area increased ninefold (Triangle Land Conservancy 
2003). When Parnell (1969) conducted his research on migrating warblers near Raleigh, NC, most study sites in his research area, a 20-mile radius circle with Raleigh at the center, were described as "beyond the influence of urbanization." Today that landscape is highly suburbanized. Cary's public greenways total $17.83 \mathrm{~km}$ (Town of Cary 2006), and Raleigh has $86.9 \mathrm{~km}$ of greenways (City of Raleigh 2006). The canopies of the greenways are dominated by hardwood trees, including red maple (Acer rubrum), sweetgum (Liquidambar styraciflua), tulip-poplar (Liriodendron tulipifera), and various oaks (Quercus spp.). Pines such as loblolly (Pinus taeda), shortleaf (Pinus echinata), and Virginia pine (Pinus virginiana) are also common. Native understory vegetation includes redbud (Cercis canadensis), blackberry (Rubus spp.), sumac (Rhus spp.), wax myrtle (Myrica cerifera), greenbrier (Smilax spp.), and wild grape (Vitis spp.). Exotic understory vegetation includes privet (Ligustrum spp.), autumn olive (Elaeagnus umbellata), Japanese honeysuckle (Lonicera japonica), and Japanese stiltgrass (Microstegium vimineum). We also surveyed three reference sites along trails in William B. Umstead State Park. The park is largely composed of second and third growth woodlands, and is situated in an urban matrix just west of Raleigh. It is the largest contiguous forested area (2,201-hectares) nearest the study greenways. Umstead State Park has $32 \mathrm{~km}$ of hiking trails and is connected to the Raleigh greenway system. Dominant hardwood species include oaks, hickory (Carya spp.), tulip-poplar, and red maple.

Study site selection.---We sampled migrating birds in 47 forested segments of public greenway during spring 2004, fall 2004, and spring 2005 (Fig. 1). The 200-m long greenway segments followed streams and were chosen to represent a range of greenway forested corridor widths and adjacent land uses. Segments were separated by at least $200 \mathrm{~m}$ with one 
exception, in which segments were separated by $192 \mathrm{~m}$. The majority of segments (39) were separated by more than $250 \mathrm{~m}$. Many of the segments overlap those used by Sinclair et al. (2005) and Mason et al. (2007). In Umstead State Park, we chose three 200-m long reference segments of trail that paralleled a stream (Fig. 1). Each of these segments was separated by at least 200 meters.

We examined leaf-off USGS 2003 high-resolution, digital orthoimages and digital land use and zoning maps in a geographic information system (ArcView 3.3) and chose segments in the following land use categories: low density residential ( $\leq 7.5$ lots/hectare), high density residential ( $>7.5$ lots/hectare), and office/institutional (businesses, schools, etc.). A segment's assigned category was based on the zoned land use within $200 \mathrm{~m}$ of the forested corridor on both sides of the segment (Fig. 2). We attempted to choose locations that had similar land use on both sides, but the use with the highest degree of development was chosen to represent the site if the sides differed. Narrow (0-75 m), medium $(76-150 \mathrm{~m})$, and wide $(>150 \mathrm{~m})$ greenways were represented within each of the land use categories, and we chose segments with relatively constant forested widths. Greenway width was considered to be the average width of the forested corridor containing the greenway path and was not limited to the legal boundary of the greenway. While a right-of-way, easement, or linear parkland can define a greenway's legal bounds, the forested area often extends into properties adjacent to the greenway path.

Land cover variables.---We quantified cover in the land bordering each segment by analyzing leaf-off aerial photography. For each study site, two 200-m x 200-m squares were drawn on each side of and parallel to the forested corridor (Fig. 2). Each square was 
populated with a systematic grid of 100 points. At each point, we assigned the land cover to the following categories: canopy, pavement, building, lawn, water, agriculture, and bare earth. In the leaf off photos, points that fell within a deciduous tree canopy were considered canopy. If land cover below a tree's canopy could be determined, both categories were recorded for the point. For each segment, we calculated the percentage of each land cover category by averaging the values calculated from the two adjacent squares.

Avian surveys.---We surveyed birds during spring migration (15 April-14 May), 2004, fall migration (3 September- 27 October), 2004, and spring migration (1 April-15 May), 2005. We performed our surveys along transects, a technique considered more effective in estimating abundance and diversity of migrating songbirds (Wilson et al. 2000, Rodewald and Brittingham 2004). We used 200-m long one-sided belt-transects with the greenway path or mowed edge, if present, as the line of travel. To keep the area surveyed as consistent as possible from greenway to greenway, we surveyed habitat on only one side of the greenway path. Locating a transect in the center of each greenway's forested corridor, though ideal, was not possible. Obstacles such as meandering streams, fences, or downed trees would have prevented an observer from completing the surveys. Observers were unable to walk down the center of the path and survey habitat on either side consistently among greenways because path and mowed edge width varied and paths were not always centrally located. We surveyed the side of the path with the widest forested area. If the two sides had roughly equal forested area, we surveyed the side with the stream.

We traversed each 200-meter-long transect slowly, pausing when flocks were encountered to ensure that all birds were counted. Surveys lasted at least 10 minutes and 
averaged 16 minutes. Rodewald and Brittingham (2004) found that detectability declined sharply in shrub and sapling habitats at 20-25 meters from their transects. We counted all birds seen and heard in the survey side within $25 \mathrm{~m}$ of the line of travel to minimize bias between greenways that have more shrubs and those that may be more open. Flyovers were not counted. We did not correct for distance and assumed a detectability of one. To minimize bias associated with weather, we did not survey during rainy or windy ( $>21 \mathrm{~km}$ per hour) conditions. During spring 2004, there were two observers. We rotated observers among greenways in different width and land use classes. In fall 2004 and spring 2005 there was one observer. During spring and fall 2004, we conducted surveys between 0700 and 1900 Eastern Standard Time (EST). To limit bias associated with the time of day, each transect was surveyed multiple times during each of the following time periods: 0700-1000; 1000-1300; 1300-1600; 1600-1900 EST. We visited ach of the 47 greenway segments and three reference sites on independent rotations within each time period to cover the range of corridor width and land use combinations. Preliminary analysis of spring 2004 data revealed that the majority of migrant bird detections occurred in the earlier part of the day, so during spring 2005, we conducted surveys between 0700 and 1300 EST. For consistency, we included only the surveys conducted before 1300 EST in our spring analyses. Because sample sizes were low during fall counts, we included surveys during all time periods in our fall analyses.

Guilds.---We classified all birds into migratory guilds and further divided Neotropical and short-distance migrants into breeding habitat guilds based on area sensitivity. Neotropical migrants were defined following Degraaf and Rappole (1995) with the following exceptions: 1) migrant birds with winter ranges that include a significant portion of the 
southeastern United States, but are not winter residents in Wake County, were classified as short distance migrants; 2) migrant birds with winter ranges that include Wake County and more northerly breeding ranges were classified as winter residents. Species present in Wake County throughout the year were classified as year-round residents. Determining the migratory status of an individual bird was not possible, so Neotropical migrants included both transients and species that breed locally. Many of the locally breeding Neotropical migrant species recorded during surveys, however, do not breed in the greenways, do not breed in the greenways in great numbers, or are breeders only in the widest $(>300 \mathrm{~m})$ greenways (Mason et al. 2007). Only three of our greenway segments exceeded $300 \mathrm{~m}$. We combined Neotropical and short distance migrants into a single migrant bird guild to focus on migrating songbirds. We divided species in the migrant bird guild into three guilds based on area sensitivity during the breeding season (Poole 2005): 1) forest-interior species are the most area-sensitive birds that prefer large contiguous habitats with interior woodland away from forest edges; 2) forest-edge species are less sensitive to patch size and use forest habitats near edges; and 3) field-edge species are birds that prefer scrub-shrub habitat often adjacent to fields. Because the number of surveys completed per season per transect were unequal, we averaged across surveys to calculate guild-level dependent variables for our analyses instead of pooling data. For each transect, we calculated migrant bird species richness as the average number of Neotropical and short distance migrant species detected per visit for each season. We calculated species richness and abundance for the forestinterior, forest-edge, and field-edge guilds in the same manner. 
Vegetation surveys.--- We chose points along each transect at 25, 75, 125, and $175 \mathrm{~m}$ to survey greenway vegetation during summer 2004. Each point was located $20 \mathrm{~m}$ from the transect survey line within the area surveyed for birds. We estimated shrub density, canopy cover, and percentage of pine and hardwood trees at each point, and we averaged the values for each of these variables across the four survey points for each transect.

We estimated shrub density using a density board that was $2.5 \mathrm{~m}$ tall and $30.48 \mathrm{~cm}$ wide and divided equally into five boxes alternating black and white (Nudds 1977). We made four shrub density readings at each point in four directions: two parallel to and two perpendicular to the greenway path. For each reading, the board was placed $15 \mathrm{~m}$ from the point. The observer stood on the survey point, estimated the percentage of each box obscured by vegetation, and assigned each box a score between zero and five corresponding to a range of percent cover in quintiles. For example, a box that was covered by greater than $0 \%$ but less than $20 \%$ was assigned a score of one, and a box that was obscured over $80 \%$ was assigned a score of five. Boxes that were completely uncovered were assigned a score of zero. We averaged scores for each of the five boxes yielding a mean shrub density score for each direction and then averaged the four directions for a mean shrub density score for each point.

We estimated canopy cover using a concave spherical densiometer. The observer stood on the survey point and estimated canopy cover while facing each of the cardinal directions and then averaged the four readings. Using a hypsometer, we estimated canopy height by measuring three of the tallest canopy trees in the vicinity of the point and then 
averaging their heights. We visually estimated the percentage of pine and hardwood trees within a $15 \mathrm{~m}$ radius circle centered on the survey point.

Though not within the area surveyed for birds, we measured the width of the path and mowed edge (together, the managed area) at $25,75,125$, and $175 \mathrm{~m}$ along the survey line to evaluate whether the opening created by the managed portion of the greenway influenced the birds found in the forested portion of the greenway. The four measurements were averaged for each transect.

Data Analysis.--- Our dependent variables were the spring and fall square-root transformed species richness and abundance values for the migrant bird, forest-interior, forest-edge, and field-edge guilds. Because of small sample sizes we did not analyze individual species responses. Our independent variables were greenway forested corridor width, vegetation measurements, and measurements of land cover in the landscape immediately adjacent to the greenway segments.

To avoid violation of the assumption of non-colinearity, we tested for correlation among all independent variables (PROC CORR, SAS Institute Inc. 2001). Two variables were considered to be highly correlated if the Pearson correlation coefficient ( $\mathrm{r}$ ) was $\geq 0.6$. We eliminated one variable from each correlated pair, and made an effort to retain the variable which was most useful for greenway planning and management. The reduced set of variables consisted of forested corridor width, five greenway vegetation measures, and five measures of adjacent land cover (Table 1). We averaged the species richness and abundance values for the two spring seasons for final analyses because preliminary analysis of each of the spring seasons yielded similar results. 
For each season, each of the eight dependent variables was regressed against the reduced set of independent variables in stepwise multiple linear regression analysis using SAS (PROC REG, SAS Institute, Inc. 2001). Only variables significant at $\mathrm{P} \leq 0.05$ were used in the final regression models.

For each season, we calculated average guild richness and abundance values for each greenway width category and compared them to the average guild richness and abundance values for the three reference segments using a one-way ANOVA and Tukey's test (FIG. 3).

\section{RESULTS}

We recorded 37 Neotropical migrants and six short distance migrants in the greenways and reference sites during the spring and fall migration surveys; 20 were forestinterior species, 16 were forest-edge species, and seven were field-edge species (Table 2).

Sample sizes were low in all seasons, especially during fall migration. During both spring migration periods, $82 \%$ of surveys detected migrants, however, during fall, only $31 \%$ of surveys recorded migrants. During spring, surveys in which migrants were detected averaged three migrant species and four individuals. The highest migrant richness recorded on a survey was 13 species and the largest abundance recorded was 27 migrants. Blue-gray gnatcatcher, Red-eyed vireo, and Gray Catbird were the most common migrants in the spring. In the fall, surveys which detected migrants averaged 1.6 species and 2.1 individuals. The highest recorded migrant richness on a fall survey was seven and the highest recorded abundance was nine. The most detected species during the fall were Gray Catbird and Rubythroated Hummingbird, and few forest interior species were recorded. 
Spring and fall migrant species richness, fall migrant abundance, spring forest-edge species richness and abundance, and fall field-edge richness and abundance increased with increasing forested corridor width (Tables 3, 4).

The greenway vegetation characteristics most commonly retained in models were canopy height and percentage of hardwood trees. During spring migration, species richness of migrants and species richness and abundance of forest-edge and forest-interior species were highest in greenways with taller trees and a greater percentage of hardwoods (Table 3). During fall migration, forest-interior richness and abundance increased with increasing canopy height while migrant richness and abundance were higher in greenways with less canopy cover (Table 4). Spring migrant abundance, fall migrant richness, and spring fieldedge richness and abundance increased with increasing shrub cover (Tables 3, 4).

Only three adjacent land cover variables were retained in the models. Spring migrant richness and field-edge species richness and abundance increased with increasing building cover (Table 3), while fall forest-edge richness and abundance increased with decreasing building cover (Table 4). Spring forest-interior richness and abundance were lowest in greenways surrounded by more pavement and bare earth (Table 3).

Average species richness and abundance of migrants during spring and fall migration was higher in the reference sites than in greenways $\leq 150 \mathrm{~m}$ wide (Fig. 3). Few field-edge species were detected in greenways and reference sites, however there were significantly more field-edge species detected in the greenways than in the reference sites. During spring, forest-edge species richness and abundance were similar in greenways $>150 \mathrm{~m}$ and in the 
reference sites (Fig. 3). During both spring and fall migration, significantly more forestinterior species were detected in the reference sites than in greenways of all widths (Fig. 3).

\section{DISCUSSION}

Forested Corridor Width.---Species richness of migrating birds during spring, and richness and abundance during fall, were highest in the widest greenway forested corridors, suggesting that wider greenways are more attractive to migrants. However, because migrant birds, especially forest-interior migrants, were detected more frequently in the reference sites than in the greenways, larger parks or reserves should be conserved in urbanizing areas.

The increase in migrant species richness and abundance in wider greenways is consistent with the finding of several studies of the effect of patch size on migrating songbirds (Martin 1980, Blake 1986, Somershoe and Chandler 2004). Martin (1980) demonstrated that migrant species richness and abundance increased with increasing area in shelterbelts on the Great Plains. Blake (1986) recorded greater species richness in larger woodlots during migration in Illinois, and Somershoe and Chandler (2004) observed a greater diversity and abundance of migrants in large hammocks than small hammocks in coastal South Carolina. Similarly, breeding migrants are more abundant in wider corridors. Species richness of breeding Neotropical migrants increased in riparian corridors wider than $100 \mathrm{~m}$ (Hodges and Krementz 1996), and Mason et al. (2007) discovered that some areasensitive migrants breed only in greenway corridors wider than $300 \mathrm{~m}$.

Though species that are area-sensitive during the breeding season also may prefer larger patches during migration, some area-sensitive migrants choose smaller habitat patches 
as stopover even when larger patches are available (Petit 2000). We routinely documented forest-interior migrants in greenways narrower than those in which they were found breeding suggesting that they were not as restricted by forested corridor width during migration. Black-throated Blue Warbler, Louisiana Waterthrush, Ovenbird, Prothonotary Warbler, Scarlet Tanager, and Yellow-throated Warbler (see Table 2 for scientific names) did not breed in greenways in our study area less than 300 m wide (Mason et al. 2007), but we recorded all of these species in greenways less than $300 \mathrm{~m}$ wide during migration. We also detected White-eyed Vireo and Indigo Bunting in greenways narrower than those in which they were recorded breeding in our study area (Mason et al. 2007). We detected migrants in the two narrowest greenways, both less than $40 \mathrm{~m}$ wide and surrounded by commercial development.

Migrating birds often are recorded in small, isolated habitat patches, and these patches may have high densities of migrants (Somershoe and Chandler 2004); however, it is unclear whether these areas offer sufficient resources to meet migrant birds' energetic needs (Graber and Graber 1983, Blake 1986). Narrow greenway segments in our study typically harbored the lowest abundances of migrants regardless of the surroundings. Unlike a small habitat patch that is completely surrounded by development, a greenway offers connectivity to other habitat patches and can provide migrants with a conduit for seeking additional habitat. Thus, migrants are not forced to remain in narrow habitats that may have fewer resources and can more easily travel to alternate locations. Petit (2000) found more fall migrants in habitat fragments that were connected by corridors than in isolated fragments of similar size. 
To accommodate the greatest diversity of migrating birds, greenway planners should work with landowners, developers, and land trusts to find creative ways to acquire the widest greenway corridors possible. Mason et al. (2007) concluded that greenway forested corridors should be at least $50 \mathrm{~m}$ wide for breeding bird habitat, and Hodges and Krementz (1996) recommend corridors greater than $100 \mathrm{~m}$. While greenways in all width categories were used by migrating songbirds, greenway segments wider than $150 \mathrm{~m}$ had the greatest abundance of migrants, especially forest-edge species, and should be conserved where possible. There are various strategies for acquiring greenway land including right-of-ways, conservation easements, and land purchase (Flink and Searns 1993). Though the most expensive option, purchasing linear parkland for greenway construction may be the best way to obtain and protect the widest corridors. In our study area, the portion of a greenway's forested corridor protected by an easement is commonly 15 meters on either side of the stream. While the removal of vegetation within that portion may be regulated, trees and shrubs adjacent to the easement or right of way may not be. Residents and business whose properties contain greenway easements or that border greenway parkland should be encouraged to retain trees and shrubs on their properties thereby increasing the forested corridor width. Designating wider stream buffers can also increase the width of a greenway corridor.

Though many forest-interior species were recorded using greenways, there were more forest-interior migrants detected in the reference sites suggesting that area-sensitive migrants may prefer larger forest patches during stopover over habitat strips like greenways. Therefore, though greenways are a popular means for conserving open space, planners 
should avoid focusing solely on greenways and incorporate large reserves into their open space master plans.

Greenway Vegetation.--- Vegetation characteristics within the greenways were better predictors of migrant species richness and abundance than the characteristics describing land cover immediately adjacent to the surveyed greenway segments. Though habitat use during migration can vary with bird species, geographic location, and season, habitats with heterogeneous vegetative structure often are those that support the most diverse and abundant migrant community (see Petit 2000 for review). In the spring, migrants occurred more commonly in hardwood-dominated greenways with taller canopies and more shrub cover. Rodewald and Brittingham (2005) found a similar relationship during spring migration in which Neotropical migrants were more abundant in urban woodlots with taller trees. During the fall, migrant richness was greater in greenways with more open canopies and more shrub cover. During spring, Rodewald and Brittingham (2005) documented higher temperate migrant abundances in urban woodlots with open canopies and heterogeneous horizontal structure.

Vegetation structure was important to migrants using the greenways in both seasons, but the significant relationship between more open canopies and the richness and abundance of migrants in the fall suggests a seasonal shift to habitats with more shrub cover. Other researchers have documented heavier use of shrub and scrub habitats during fall migration (Suthers et al. 2000, Swanson et al. 2003, Rodewald and Brittingham 2004). Greenways with canopy gaps or low canopy coverage allow sunlight to reach the forest floor thereby stimulating understory growth. Migrants may be attracted to these gaps and open areas 
because they are higher quality habitat with greater arthropod abundances and more fruiting shrubs in the fall. Gaps with dense shrub or midstory growth may also offer birds protection from predators during migration, a period when they are especially vulnerable (Bowen et al. 2007). Because we did not measure subcanopy height, we are unable to determine to whether birds more abundant in greenways with more open canopies may have been attracted to this vegetation layer in addition to the shrubs.

While development-sensitive breeding birds were least abundant in greenways in our study area with more extensive managed area along the recreational trails (Mason et al. 2007), we failed to document a similar relationship between managed area and migrating birds, indicating that migrating birds may not be as sensitive to the division of habitat created by the greenway path and associated maintained areas. In fact, trail management activities may indirectly benefit migrants because the greenway path and mowed edges create a canopy opening within the forested corridor that allows sunlight in and promotes the growth of shrubs and saplings along the path that may attract migrants. Rodewald and Brittingham (2002) documented the highest species richness and abundance of fall migrants along forest edges with high densities of shrubs and saplings.

Maintaining shrubs and other understory vegetation within a greenway is a balance between conserving habitat, maintaining aesthetics, and providing safe public spaces (Luymes and Tamminga 1995). Dense shrubs can create the perception for some people that an area is unsafe; however, removing bushes and shrubs, especially those which produce fruit in the fall, could reduce the quality of greenways as stopover habitat by reducing the amount of food and cover available. Residents near a proposed greenway trail in our study area who 
were surveyed regarding their concerns about the trail often commented that shrubs should be removed to improve trail visibility and to eliminate potential hiding places for those with nefarious intentions (Ivy 2001). Avoiding indiscriminate understory clearing and restricting shrub pruning and removal to areas of reduced visibility can increase safety and maximize habitat potential. The necessary removal of shrubs can be offset by planting native fruiting shrubs elsewhere in the greenway. During the construction of a new greenway path, clearing should be reduced to the minimum necessary for activities such as grading, paving, and bridge construction.

Adjacent Land Use.---The adjacent land cover variables generally were poor predictors of migrant species richness and abundance. Adjacent building coverage was the most frequently retained variable in final models, but the relationships were inconsistent. During spring migration, we recorded more migrant species and higher field-edge species richness and abundance in greenways with higher adjacent building cover, but forest-edge species richness and abundance increased with decreasing building cover adjacent to the greenways in the fall. Mason et al. (2007) recorded fewer Neotropical migrants breeding in greenways with more adjacent building cover. Similarly, Friesen et al. (1995) recorded fewer breeding Neotropical migrants in woodlots surrounded by more houses. During migration, Rodewald and Matthews (2005) found no statistical relationship between migrants and the percentage of urban land within one kilometer of their study sites; however, though not significant, they did document a weak relationship between urbanization and temperate migrants. 
It seems counterintuitive that greater migrant richness in the greenways would be associated with more building cover in the adjacent landscape. This relationship may explained by an indirect attraction to residential neighborhoods. Migrating songbirds often congregate in mixed species flocks with other migrants and resident birds, especially chickadees and titmice, to increase foraging efficiency or to gain protection from predators (Morse 1970, Berner and Grubb 1985, Rodewald and Brittingham 2002, Hobson and Van Wilgenberg 2006). Chickadees and titmice are common in residential areas and are attracted to bird feeders or other resources there. Migrating songbirds associating with them also may appear attracted to residences. Chickadees and titmice were recorded in surveys with the greatest richness of migrants; however, we did not collect information on individual flocks, so we are unable to determine whether migrants detected in our surveys were being led by resident birds.

An association with high building cover adjacent to the greenway may also be explained by a lack of suitable habitat in built-up areas. Some office complexes and high density residential neighborhoods may have few trees and shrubs thereby relegating migrants to the greenway, while low density residential neighborhoods often have more trees and shrubs allowing migrants to forage beyond the greenway corridor. Field-edge richness and abundance in the fall was higher in greenways with fewer adjacent buildings. The influence of vegetation composition and structure in residential neighborhoods on the abundance and richness of migrants, as well as resident birds, in greenways is an area of future study.

Some migrants may avoid stopping over in greenways located in built-up areas. During spring migration, we recorded fewer forest-interior species and individuals in 
greenways with high adjacent pavement and bare ground cover which are indicators of intense development to which forest-interior species are sensitive. Similarly, Mason et al. (2007) recorded fewer Neotropical migrants breeding in greenways with high adjacent pavement cover and bare earth, and observed a decline in forest-interior species as bare earth adjacent to the greenways increased.

Spring vs. fall migration.---Though sample sizes were low during spring, even fewer migrants were encountered during fall surveys, especially forest-interior migrants. As a result, the fall forest-edge and forest-interior models had low $\mathrm{R}^{2}$ values and should be interpreted with caution. Detection can be more difficult in fall when migrants are cryptically colored and less vocal. In an attempt to increase detections, following the transect surveys we performed point counts using playbacks of owl vocalizations and chickadee and titmouse mobbing calls. The use of mobbing calls prior to a count can increase the richness and abundance of birds surveyed during the non-breeding season (Turcotte and Desrochers 2002). The counts rarely detected additional migrants, and we did not use them in the analysis. Seasonal divergences in migration route may affect the abundances of some species (Weisbrod et al 1993), so it is possible that fewer migrants passed through the area during fall migration.

Design and Management Recommendations.---One of the greatest challenges to conserving and managing habitat for migratory birds is the need for a diversity of habitats that can accommodate migrants during multiple phases of their annual cycle. Management recommendations employed for breeding migrants may not be sufficient to accommodate those species during spring and fall migration. Many of the associations between birds and 
greenway characteristics are the same during migration as during the breeding season. Greenways might be able to accommodate migrants during both the breeding and nonbreeding season if designed using the following recommendations:

1. Avoid removing shrub and ground cover within the greenway to maintain vegetative complexity and provide habitat for a wider variety of migrants during both spring and fall migration.

2. Conserve greenways with forested corridors that are greater than $150 \mathrm{~m}$ wide wherever possible. Even the widest greenways, on average, harbored fewer migrants than the reference sites in Umstead State Park.

3. Construct new greenways in areas where there is lower development intensity. Areas with fewer buildings, less pavement, and less bare earth are more likely to have more canopy and shrub cover that can compliment the habitat in the greenway and together create a wider corridor or larger habitat area.

4. Do not limit open space planning to greenways. Establish larger patches of habitat such as city, county, or state parks in conjunction with greenways.

\section{ACKNOWLEDGMENTS}

We thank Marcia Gumpertz for her guidance with the statistical analysis. We thank Ted Simons for his aid in designing this study and for his review of this manuscript. The City of Raleigh, the Town of Cary, and William B. Umstead State Park provided generous access to their lands; Wake County GIS, City of Raleigh GIS, and Town of Cary GIS furnished the geographic data; and Nathan Tarr assisted in conducting avian surveys. The 
USDA Forest Service and the North Carolina State University Department of Forestry and Environmental Resources provided financial support for the project.

\section{LITERTURE CITED}

Alig, R. J., J. D. Kline, and M. Lichtenstein. 2004. Urbanization on the US landscape: looking ahead in the 21st century. Landscape and Urban Planning 69:219-234.

Askins, R. A., J. F. Lynch, and R. Greenberg. 1990. Population declines in migratory birds in eastern North America. Current Ornithology 7:1-57.

Bessinger, S. R. and D. R. Osborne. 1982. Effects of urbanization on avian community organization. Condor 84:75-83.

Berner, T. O. and T. C. Grubb, Jr. 1985. An experimental analysis of mixed-species flocking in birds of deciduous woodland. Ecology 66:1229-1236.

Blake, J. G. 1986. Species area relationships of migrants in isolated woodlots in east-central Illinois. Wilson Bulletin 98:291-296.

Blake, J. G. and W. G. Hoppes. 1986. Influence of resource abundance on use of tree-fall gaps by birds in an isolated woodlot. Auk 103:328-340.

Blem, C. 1980. The energetics of migration. Pages 175-224 in Animal migration orientation and navigation (S. A. Gauthreaux, Ed.). Academic Press, New York, USA.

Bowen, L. T., C. E. Moorman, and J. C. Kilgo. 2007. Seasonal bird use of canopy gaps in a bottomland forest. Wilson Journal of Ornithology 119:77-89.

Chernetsov, N. 2006. Habitat selection by nocturnal passerine migrants en route: mechanisms and results. Journal of Ornithology 147:185-191. 
City of Raleigh. 2006. http://raleighnc.gov (accessed 1 August 2006).

Degraaf, R. M. and J. H. Rappole. 1995. Neotropical migratory birds: natural history, distribution, and population change. Cornell University Press, Ithaca, New York.

Emlen, J. T. 1974. An urban bird community in Tucson, Arizona: derivation, structure, regulation. Condor 76:184-197.

Faaborg, John 2002. Saving migrant birds: developing strategies for the future. University of Texas Press, Austin, USA.

Flink, C. A. and R. M. Searns. 1993 Greenways: a guide to planning, design, and development. Island Press Washington, D.C., USA.

Friesen, L. E., P. F. J. Eagles, and R. J. Mackay. 1995. Effects of residential development on forest-dwelling Neotropical migrant songbirds. Conservation Biology 9:1408-1414.

Graber, R. R. and J. W. Graber. 1963. A comparative study of bird populations in Illinois, 1906-1909 and 1956-1958. Illinois Natural History Survey Bulletin 28:468-469.

Graber, J. W. and R. R. Graber. 1983. Feeding rates of warblers in spring. Condor 85:139150.

Hagan, J. M., T. L. Lloyd-Evans, J. L. Atwood, and D. S. Wood. 1992. Long-term changes in migratory landbirds in the northeastern United States: evidence from migration capture data. Pages 115-130 in Ecology and conservation of Neotropical migrant landbirds (J. M. Hagan III and D. W. Johnston, Eds.). Smithsonian Institution, Washington, D.C., USA.

Hagan, J. M. III and D.W. Johnston 1992. Ecology and conservation of Neotropical migratory landbirds. Smithsonian Institution Press, Washington, D.C., USA. 
Hay, K. G. Greenways and biodiversity. 1991. Pages 162-175 in Landscape Linkages and Biodiversity (W. E. Hudson, Ed.). Island Press, Washington, D.C., USA.

Hobson, K. A. and S. Van Wilgenburg. 2006. Composition and timing of postbreeding multispecies feeding flocks of boreal forest passerines in western Canada. Wilson Journal of Ornithology 118:164-172.

Hodges, M. F. Jr., and D. G. Krementz. 1996. Neotropical migratory breeding bird communities in riparian forests of different widths along the Altamaha River, Georgia. Wilson Bulletin 108:496-506.

Hostetler, M., S. Duncan, and J. Paul. 2005. Post-construction effects of an urban development on migration, resident, and wintering birds. Southeastern Naturalist $4: 421-434$.

Ivy, M. I. 2001. Predicting attitudes towards a proposed greenway trail: the role of past experience. Ph.D. dissertation, North Carolina State University, Raleigh, USA.

Little, C. E. 1990. Greenways for America. Johns Hopkins University Press, Baltimore, Maryland, USA.

Luymes, D. T. and K. Tamminga. 1995. Integrating public safety and use into planning urban greenways. Landscape and Urban Planning 33:391-400.

Martin, T. E. 1980. Diversity and abundance of spring migratory birds using habitat islands in the great plains. Condor 82:430-439.

Mason, J. H., C. E. Moorman, G. R. Hess, and K. E. Sinclair. 2007. Designing suburban greenways to provide habitat for forest-breeding birds. Landscape and Urban Planning 80:153-164. 
Moore, F. R. 2000. Stopover ecology of Nearctic-Neotropical landbird migrants: habitat relations and conservation implications. Studies in Avian Biology 20.

Moore, F. R., S. A. Gauthreaux, P. Kerlinger, and T. R. Simons. 1993. Stopover habitat: management implications and guidelines. Pages 58-69 in Status and management of Neotropical migratory birds. (D. M. Finch and P. W. Stangel, Eds.). General Technical Report RM-229. USDA Forest Service, Rocky Mountain Research Station, Fort Collins, Colorado, USA.

Moore, F. R., S. A. Gauthreaux, Jr., P. Kerlinger, and T. R. Simons. 1995. Habitat requirements during migration: important link in conservation. Pages 121-144 in Ecology and management of Neotropical migratory birds: a synthesis and review of critical issues (T. E. Martin and D. M. Finch, Eds.). Oxford University Press, New York, USA.

Moore, F. R. and D. A. Aborn. 2000. Mechanisms of en route habitat selection: how do migrants make habitat decisions during stopover? Studies in Avian Biology 20:34-42.

Morse, D. H. 1970. Ecological aspects of some mixed-species foraging flocks of birds. Ecological Monographs 40:119-168.

Newton, I. 2006. Can conditions experiences during migration limit the population levels of birds? Journal of Ornithology 147:146-166.

Nudds, T. D. 1977. Quantifying the vegetative structure of wildlife cover. Wildlife Society Bulletin 5:113-117.

Parnell, J. F. 1969. Habitat relations of the Parulidae during spring migration. Auk 86:505 521. 
Petit, D. R. 2000. Habitat use by landbirds along Nearctic-Neotropical migration routes: implications for conservation of stopover habitats. Studies in Avian Biology 20:1533.

Poole, A. (Ed.). 2005. The Birds of North American Online: http://www.lib.ncsu.edu:3935/BNA/. Cornell Laboratory of Ornithology, Ithaca, New York, USA.

Robbins, C. S., J. R. Sauer, R. S. Greenberg, and S. Droege. 1989. Population declines in North American birds that migrate to the Neotropics. Proceedings of the National Academy of Sciences USA 86:7658-7662.

Rodewald, P. G. and M. C. Brittingham. 2002. Habitat use and behavior of mixed species landbird flocks during fall migration. 2002. Wilson Bulletin 114:87-98.

Rodewald, P. G. and M. C. Brittingham. 2004. Stopover habitats of landbirds during fall: use of edge-dominated and early-successional forests. Auk 121:1040-1055.

Rodewald, P. G. and S. N. Matthews. 2005. Landbird use of riparian and upland forest stopover habitats in an urban landscape. Condor 107:259-268.

SAS Institute, Inc. 2001. SAS ver. 8.2. SAS Institute, Inc. Cary, North Carolina, USA.

Searns, R. M. 1995. The evolution of greenways as an adaptive urban landscape form. Landscape and Urban Planning 33:65-80.

Sillett, T. S. and R. T. Holmes. 2002. Variation in survivorship of a migratory songbird through its annual cycle. Ecology 71:296-308.

Sinclair, K. E., G. R. Hess, C. E. Moorman, and J. H. Mason. 2005. Mammalian nest 
predators respond to greenway width, landscape context, and habitat structure. Landscape and Urban Planning 71:277-293.

Somershoe, S. G. and C. R. Chandler. 2004. Use of oak hammocks by Neotropical migrant songbirds: the role of area and habitat. Wilson Bulletin 116:56-63.

Town of Cary. 2006. Town of Cary greenways and trails. http://townofcary.org/depts/prdept/greenway/gwyhome.htm (accessed 1 August 2006).

Turcotte, Y. and A. Desrochers. 2002. Playbacks of mobbing calls of Black-capped Chickadees help estimate the abundance of forest birds in winter. Journal of Field Ornithology 73:303-307.

Triangle Land Conservancy. 2003. State of open space 2002: the status of the Triangle's green infrastructure. Raleigh, North Carolina, USA.

Wake County. 2002. Wake County: opportunities and challenges. www.wakegov.com/about/communityassessment.htm (accessed 1 August 2006).

Weisbrod, A. R., C. J. Burnett, J. G. Turner and D. W. Warner. 1993. Migrating birds at a stopover site in the Saint Croix river valley. Wilson Bulletin 190:265-284.

Wilson, R. R., D. J. Twedt, and A. B. Elliott. 2000. Comparison of line transects and point counts for monitoring spring migration in forested wetlands. Journal of Field Ornithology 71:345-355. 
TABLE 1. Description of independent variables used in stepwise multiple regression analysis on guild species richness and abundance measures from Raleigh and Cary, NC greenways (2004-2005).

\begin{tabular}{|c|c|}
\hline Independent Variable & Description \\
\hline Corridor width & $\begin{array}{l}\text { Average width }(\mathrm{m}) \text { of the forested corridor of each } 200-\mathrm{m} \text { long } \\
\text { surveyed segment }\end{array}$ \\
\hline \multicolumn{2}{|l|}{ Land Cover Measures } \\
\hline Adjacent bare earth & Percent bare earth cover in land adjacent to the segment ${ }^{\mathrm{d}}$ \\
\hline Adjacent building & Percent building cover in land adjacent to the segment ${ }^{\mathrm{d}}$ \\
\hline Adjacent canopy & Percent canopy cover in land adjacent to the segment ${ }^{\mathrm{d}}$ \\
\hline Adjacent lawn & Percent lawn cover in land adjacent to the segment ${ }^{\mathrm{d}}$ \\
\hline Adjacent pavement & Percent pavement cover in land adjacent to the segment ${ }^{\mathrm{d}}$ \\
\hline \multicolumn{2}{|c|}{ Greenway Vegetation Measures } \\
\hline Canopy cover & Percent canopy cover within the segment's forested corridor ${ }^{\mathrm{a}, \mathrm{e}}$ \\
\hline Canopy height & Canopy height within the segment's forested corridor ${ }^{b}$, e \\
\hline Managed area & $\begin{array}{l}\text { Width of the path and mowed border adjacent to the area surveyed } \\
\text { for birds }\end{array}$ \\
\hline Percent hardwoods & Percentage of hardwoods within the segment ${ }^{\mathrm{e}}$ \\
\hline Shrub cover & Index of percent shrub cover in the segment ${ }^{\mathrm{c}, \mathrm{e}}$ \\
\hline
\end{tabular}

\footnotetext{
${ }^{a}$ Measurements made using a concave spherical densitometer.

${ }^{\mathrm{b}}$ Measurements made using a digital hypsometer.

${ }^{\mathrm{c}}$ Measurements made using a density board (Nudds 1977).

${ }^{\mathrm{d}}$ Average percent cover within two 200 X $200 \mathrm{~m}$ areas adjacent to either side of the greenway segment measured on aerial photographs in a GIS.

${ }^{\mathrm{e}}$ Averaged across four points within the portion of the transect surveyed for birds.
} 
TABLE 2. Migrant bird species occurrences in greenways and reference sites presented by adjacent land use and width categories. Each cell contains the number of segments in the corresponding category in which the species was recorded during spring migration (S) (2004-2005) or fall migration (F) (2004). Adjacent land use categories are: LDR, low-density residential ( $\leq 7.5$ lots/hectare); HDR, high-density residential (>7.5 lots/hectare); OFC, Office/Institutional. Reference segments are indicated by REF.

\begin{tabular}{|c|c|c|c|c|c|c|c|c|c|c|c|c|c|c|}
\hline \multirow{4}{*}{ Number of Sites } & \multicolumn{6}{|c|}{ Adjacent Land Use } & \multicolumn{6}{|c|}{ Forested Corridor Width (m) } & & \\
\hline & \multirow{2}{*}{\multicolumn{2}{|c|}{$\begin{array}{l}\text { LDR } \\
(19)\end{array}$}} & \multirow{2}{*}{\multicolumn{2}{|c|}{$\begin{array}{l}\text { HDR } \\
\text { (12) }\end{array}$}} & \multirow{2}{*}{\multicolumn{2}{|c|}{$\begin{array}{l}\text { OFC } \\
(16)\end{array}$}} & \multirow{2}{*}{\multicolumn{2}{|c|}{$\begin{array}{l}0-75 \\
(10)\end{array}$}} & \multirow{2}{*}{\multicolumn{2}{|c|}{$\begin{array}{c}76-150 \\
(23)\end{array}$}} & \multirow{2}{*}{\multicolumn{2}{|c|}{$\begin{array}{c}>150 \\
(14)\end{array}$}} & \multirow{2}{*}{\multicolumn{2}{|c|}{$\begin{array}{l}\text { REF } \\
(3)\end{array}$}} \\
\hline & & & & & & & & & & & & & & \\
\hline & $\mathrm{S}$ & $\mathrm{F}$ & $\mathrm{S}$ & $\mathrm{F}$ & $\mathrm{S}$ & $\mathrm{F}$ & $\mathrm{S}$ & $\mathrm{F}$ & $\mathrm{S}$ & $\mathrm{F}$ & $\mathrm{S}$ & $\mathrm{F}$ & $\mathrm{S}$ & $\mathrm{F}$ \\
\hline \multicolumn{15}{|l|}{ Field-edge Species } \\
\hline Blue Grosbeak (Guiraca caerulea) $^{\mathrm{n}}$ & & & & & 1 & & & & 1 & & & & & \\
\hline Blue-winged Warbler (Vermivora pinus) & & & & 1 & & & & & & & & 1 & & \\
\hline Common Yellowthroat (Geothlypis trichas) ${ }^{\mathrm{s}}$ & 11 & 2 & 8 & 2 & 12 & 5 & 6 & 1 & 15 & 4 & 10 & 4 & 1 & \\
\hline House Wren (Troglodytes aedon) ${ }^{\mathrm{s}}$ & 4 & & 4 & & 2 & & 2 & & 7 & & 1 & & & \\
\hline Indigo Bunting (Passerina cyanea $)^{\mathrm{n}}$ & 3 & & 1 & & 2 & & 1 & & 2 & & 3 & & & \\
\hline Prairie Warbler (Dendroica discolor $)^{\mathrm{n}}$ & 2 & & & & & & 1 & & 1 & & & & & \\
\hline 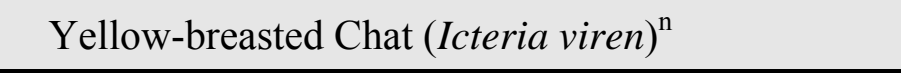 & & & & & 1 & & & & & & 1 & & & \\
\hline
\end{tabular}




\begin{tabular}{|c|c|c|c|c|c|c|c|c|c|c|c|c|c|c|}
\hline \multirow[b]{3}{*}{ Guild/Species } & \multicolumn{6}{|c|}{ Adjacent Land Use } & \multicolumn{6}{|c|}{ Forested Corridor Width (m) } & & \\
\hline & \multicolumn{2}{|c|}{$\begin{array}{l}\text { LDR } \\
(19)\end{array}$} & \multicolumn{2}{|c|}{$\begin{array}{c}\text { HDR } \\
(12)\end{array}$} & \multicolumn{2}{|c|}{$\begin{array}{l}\text { OFC } \\
(16)\end{array}$} & \multicolumn{2}{|c|}{$\begin{array}{l}0-75 \\
(10)\end{array}$} & \multicolumn{2}{|c|}{$\begin{array}{c}76-150 \\
(23)\end{array}$} & \multicolumn{2}{|c|}{$\begin{array}{c}>150 \\
(14)\end{array}$} & \multicolumn{2}{|c|}{$\begin{array}{c}\text { REF } \\
\text { (3) }\end{array}$} \\
\hline & $\mathrm{S}$ & $\mathrm{F}$ & $\mathrm{S}$ & $\mathrm{F}$ & $\mathrm{S}$ & $\mathrm{F}$ & $\mathrm{S}$ & $\mathrm{F}$ & $\mathrm{S}$ & $\mathrm{F}$ & $\mathrm{S}$ & $\mathrm{F}$ & $\mathrm{S}$ & $\mathrm{F}$ \\
\hline \multicolumn{15}{|l|}{ Forest-edge Species } \\
\hline Baltimore Oriole (Icterus galbula) ${ }^{\mathrm{n}}$ & 1 & & 1 & & & & & & 2 & & & & & \\
\hline Blue-gray Gnatcatcher (Polioptila caerulea) ${ }^{\mathrm{n}}$ & 17 & 1 & 12 & & 16 & 1 & 8 & & 23 & & 14 & 2 & 3 & \\
\hline Blackpoll Warbler (Dendroica striata) ${ }^{\mathrm{n}}$ & 12 & & 5 & 1 & 6 & & 4 & & 14 & 1 & 5 & & & \\
\hline Eastern Kingbird (Tyrannus tyrannus) ${ }^{\mathrm{n}}$ & & & 1 & & 3 & & & & 1 & & 3 & & & \\
\hline Eastern Wood-Pewee (Contopus virens) ${ }^{\mathrm{n}}$ & 2 & & & & 2 & 2 & & & 3 & & 1 & 2 & 2 & 1 \\
\hline Great Crested Flycatcher (Myiarchus crinitus) ${ }^{\mathrm{n}}$ & 15 & 1 & 6 & & 12 & & 5 & & 16 & 1 & 12 & & 3 & \\
\hline Gray Catbird (Dumetella carolinensis) ${ }^{\mathrm{s}}$ & 17 & 6 & 11 & 8 & 13 & 8 & 8 & 6 & 20 & 6 & 13 & 10 & & \\
\hline Magnolia Warbler (Dendroica magnolia) ${ }^{\mathrm{n}}$ & 1 & 1 & & 1 & & & & 1 & 1 & & & 1 & & 1 \\
\hline Orchard Oriole (Icterus spurius) $)^{\mathrm{n}}$ & & & 1 & & 2 & & & & 2 & & 1 & & & \\
\hline $\begin{array}{l}\text { Rose-breasted Grosbeak (Pheucticus } \\
\text { ludovicianus) }\end{array}$ & 1 & & 1 & & 1 & & & & 2 & & 1 & & & \\
\hline Red-eyed Vireo (Vireo olivaceus) ${ }^{\mathrm{n}}$ & 15 & & 8 & & 12 & 2 & 6 & & 16 & & 13 & 2 & 3 & 1 \\
\hline $\begin{array}{l}\text { Ruby-throated Hummingbird (Archilochus } \\
\text { colubris) }\end{array}$ & 9 & 5 & 12 & 3 & 12 & 8 & 7 & 1 & 12 & 7 & 14 & 8 & 3 & \\
\hline Summer Tanager (Piranga rubra) & 2 & & & & 7 & & & & 5 & & 4 & & 2 & \\
\hline
\end{tabular}




\begin{tabular}{|c|c|c|c|c|c|c|c|c|c|c|c|c|c|c|}
\hline \multirow[b]{3}{*}{ Guild/Species } & \multicolumn{6}{|c|}{ Adjacent Land Use } & \multicolumn{6}{|c|}{ Forested Corridor Width (m) } & & \\
\hline & \multicolumn{2}{|c|}{$\begin{array}{l}\text { LDR } \\
(19)\end{array}$} & \multicolumn{2}{|c|}{$\begin{array}{l}\text { HDR } \\
(12)\end{array}$} & \multicolumn{2}{|c|}{$\begin{array}{l}\text { OFC } \\
(16)\end{array}$} & \multicolumn{2}{|c|}{$\begin{array}{l}0-75 \\
(10)\end{array}$} & \multicolumn{2}{|c|}{$\begin{array}{c}76-150 \\
(23)\end{array}$} & \multicolumn{2}{|c|}{$\begin{array}{l}>150 \\
(14)\end{array}$} & \multicolumn{2}{|c|}{$\begin{array}{c}\text { REF } \\
\text { (3) }\end{array}$} \\
\hline & $\mathrm{S}$ & $\mathrm{F}$ & $\mathrm{S}$ & $\mathrm{F}$ & $\mathrm{S}$ & $\mathrm{F}$ & $\mathrm{S}$ & $\mathrm{F}$ & $\mathrm{S}$ & $\mathrm{F}$ & $\mathrm{S}$ & $\mathrm{F}$ & $\mathrm{S}$ & $\mathrm{F}$ \\
\hline White-eyed Vireo (Vireo griseus) ${ }^{\mathrm{s}}$ & 3 & & 5 & & 9 & 1 & 1 & & 8 & 1 & 8 & & & \\
\hline Palm Warbler (Dendroica palmarum $)^{\mathrm{n}}$ & & & 1 & & & & & & 1 & & & & & \\
\hline Yellow Warbler (Dendroica petechia) ${ }^{\mathrm{n}}$ & 2 & & 2 & & 3 & & 1 & & 4 & & 2 & & & \\
\hline \multicolumn{15}{|l|}{ Forest-interior Species } \\
\hline Acadian Flycatcher (Epidomax virscens) ${ }^{\mathrm{n}}$ & 7 & 1 & 5 & & 3 & & 1 & & 7 & 1 & 7 & & 3 & \\
\hline American Redstart (Setophaga ruticilla) ${ }^{\mathrm{n}}$ & 11 & 3 & 6 & 1 & 6 & 1 & 5 & 1 & 12 & 3 & 6 & 1 & 1 & 3 \\
\hline Black-and-white Warbler (Mniotilta varia $)^{\mathrm{n}}$ & 10 & & 6 & & 5 & 1 & 1 & & 12 & & 8 & 1 & 3 & 2 \\
\hline Blue-headed Vireo (Vireo solitarius) ${ }^{\mathrm{s}}$ & 3 & 1 & 1 & 1 & 2 & 1 & & 1 & 3 & 1 & 3 & 1 & 1 & \\
\hline $\begin{array}{l}\text { Black-throated Blue Warbler (Dendroica } \\
\text { caerulescens) }^{\mathrm{n}}\end{array}$ & 13 & & 5 & & 6 & 1 & 5 & & 10 & & 9 & 1 & 1 & 2 \\
\hline $\begin{array}{l}\text { Black-throated Green Warbler (Dendroica } \\
\text { virens) }^{\mathrm{n}}\end{array}$ & 1 & 1 & & & 1 & & & & 1 & 1 & 1 & & 1 & 1 \\
\hline Canada Warbler (Wilsonia mericana $)^{\mathrm{n}}$ & & & 1 & & & & & & 1 & & & & & \\
\hline Hooded Warbler (Wilsonia merica) ${ }^{\mathrm{n}}$ & 7 & 1 & 2 & & 3 & & 2 & & 6 & 1 & 4 & & 1 & \\
\hline Kentucky Warbler (Oporornis formosus) ${ }^{\mathrm{n}}$ & & & & & 1 & & & & & & 1 & & & \\
\hline Louisiana Waterthrush (Seiurus motacilla) ${ }^{\mathrm{n}}$ & 3 & & 3 & & 2 & & & & 4 & & 4 & & 1 & \\
\hline
\end{tabular}




\begin{tabular}{|c|c|c|c|c|c|c|c|c|c|c|c|c|c|c|}
\hline \multirow{4}{*}{ Number of Sites } & \multicolumn{6}{|c|}{ Adjacent Land Use } & \multicolumn{6}{|c|}{ Forested Corridor Width (m) } & & \\
\hline & \multirow{2}{*}{\multicolumn{2}{|c|}{$\begin{array}{l}\text { LDR } \\
\text { (19) }\end{array}$}} & \multirow{2}{*}{\multicolumn{2}{|c|}{$\begin{array}{l}\text { HDR } \\
\text { (12) }\end{array}$}} & \multirow{2}{*}{\multicolumn{2}{|c|}{$\begin{array}{l}\text { OFC } \\
(16)\end{array}$}} & \multirow{2}{*}{\multicolumn{2}{|c|}{$\begin{array}{l}0-75 \\
(10)\end{array}$}} & \multirow{2}{*}{\multicolumn{2}{|c|}{$\begin{array}{c}76-150 \\
(23) \\
\end{array}$}} & \multirow{2}{*}{\multicolumn{2}{|c|}{$\begin{array}{l}>150 \\
(14) \\
\end{array}$}} & \multirow{2}{*}{\multicolumn{2}{|c|}{$\begin{array}{c}\text { REF } \\
\text { (3) }\end{array}$}} \\
\hline & & & & & & & & & & & & & & \\
\hline & $\mathrm{S}$ & $\mathrm{F}$ & $\mathrm{S}$ & $\mathrm{F}$ & $\mathrm{S}$ & $\mathrm{F}$ & $\mathrm{S}$ & $\mathrm{F}$ & $\mathrm{S}$ & $\mathrm{F}$ & $\mathrm{S}$ & $\mathrm{F}$ & $\mathrm{S}$ & $\mathrm{F}$ \\
\hline${\text { Northern Parula (Parula mericana })^{\mathrm{n}}}$ & 15 & & 10 & & 11 & & 7 & & 17 & & 12 & & 3 & \\
\hline Northern Waterthrush (Seiurus noveboracensis) $^{\mathrm{n}}$ & 3 & & & & & & 1 & & & & 2 & & & \\
\hline Ovenbird (Seiurus aurocapillus) $^{\mathrm{n}}$ & 7 & & 3 & & 7 & & 1 & & 7 & & 9 & & 2 & \\
\hline Prothonotary Warbler (Protonotaria citrea $)^{\mathrm{n}}$ & & & & & 1 & & 1 & & & & & & & \\
\hline Scarlet Tanager (Piranga olivacea $)^{\mathrm{n}}$ & 7 & & 1 & & 3 & & 2 & & 6 & & 3 & & & \\
\hline Swainson's Thrush (Catharus ustulatus) ${ }^{\mathrm{n}}$ & 1 & & 1 & & 1 & & 2 & & 1 & & & & & \\
\hline Veery (Catharus fuscescens) $^{\mathrm{n}}$ & 2 & & & & & & & & 1 & & 1 & & & \\
\hline Worm-eating Warbler (Helmitheros vermivorus) ${ }^{\mathrm{n}}$ & & & 2 & & 1 & & & & & & 3 & & 1 & 1 \\
\hline Wood Thrush (Hylocichla mustelina $)^{\mathrm{n}}$ & 10 & 2 & 8 & 3 & 4 & 1 & 2 & & 12 & 4 & 8 & 2 & 1 & \\
\hline Yellow-throated Warbler (Dendroica dominica) ${ }^{\mathrm{n}}$ & & & & & 1 & & & & & & 1 & & 3 & \\
\hline
\end{tabular}

${ }^{\mathrm{n}}$ Neotropical migrant

${ }^{\mathrm{s}}$ Short distance migrant 


\begin{tabular}{|c|c|c|c|c|c|c|c|c|c|c|c|}
\hline \multirow[b]{2}{*}{$\begin{array}{c}\text { Dependent } \\
\text { Variable* }\end{array}$} & \multirow[b]{2}{*}{$\begin{array}{c}\text { Model } \\
\mathrm{R}^{2}\end{array}$} & \multirow[b]{2}{*}{ Model P } & \multirow[b]{2}{*}{ Intercept } & \multirow[b]{2}{*}{$\begin{array}{c}\text { Forested } \\
\text { Width }\end{array}$} & \multicolumn{4}{|c|}{ Greenway Composition and Structure } & \multicolumn{3}{|c|}{ Adjacent Land Use } \\
\hline & & & & & $\begin{array}{c}\text { Canopy } \\
\text { Cover }\end{array}$ & $\begin{array}{c}\text { Canopy } \\
\text { Height }\end{array}$ & $\begin{array}{l}\text { Hard- } \\
\text { woods }\end{array}$ & $\begin{array}{l}\text { Shrub } \\
\text { Cover }\end{array}$ & $\begin{array}{c}\text { Building } \\
\text { Cover }\end{array}$ & $\begin{array}{l}\text { Pavement } \\
\text { Cover }\end{array}$ & $\begin{array}{l}\text { Bare } \\
\text { Earth }\end{array}$ \\
\hline \multirow{2}{*}{$\begin{array}{l}\text { Migrant } \\
\text { Richness }\end{array}$} & 0.583 & $\mathrm{P}<0.001$ & -0.5165 & 0.0019 & & 0.0064 & 0.0105 & & 0.0152 & & \\
\hline & & & & $\mathrm{P}<0.001$ & & $\mathrm{P}=0.008$ & $\mathrm{P}<0.001$ & & $\mathrm{P}=0.029$ & & \\
\hline \multirow{2}{*}{$\begin{array}{l}\text { Migrant } \\
\text { Abundance }\end{array}$} & 0.362 & $\mathrm{P}<0.001$ & -0.1234 & & & & 0.0151 & 0.1639 & & & \\
\hline & & & & & & & $\mathrm{P}<0.001$ & $\mathrm{P}=0.010$ & & & \\
\hline \multirow{2}{*}{$\begin{array}{l}\text { Field-edge } \\
\text { Richness }\end{array}$} & 0.221 & $\mathrm{P}=0.004$ & 0.0890 & & & & & 0.1019 & 0.0128 & & \\
\hline & & & & & & & & $\mathrm{P}=0.005$ & $\mathrm{P}=0.020$ & & \\
\hline \multirow{2}{*}{$\begin{array}{l}\text { Field-edge } \\
\text { Abundance }\end{array}$} & 0.323 & $\mathrm{P}<0.001$ & 0.4298 & & -0.0067 & & & 0.1839 & 0.0185 & & \\
\hline & & & & & $\mathrm{P}=0.029$ & & & $\mathrm{P}<0.001$ & $\mathrm{P}=0.013$ & & \\
\hline \multirow{2}{*}{$\begin{array}{l}\text { Forest-edge } \\
\text { Richness }\end{array}$} & 0.641 & $\mathrm{P}<0.001$ & -0.4613 & 0.0013 & & 0.0040 & 0.0108 & & & & \\
\hline & & & & $\mathrm{P}<0.001$ & & $\mathrm{P}=0.033$ & $\mathrm{P}<0.001$ & & & & \\
\hline \multirow{2}{*}{$\begin{array}{l}\text { Forest-edge } \\
\text { Abundance }\end{array}$} & 0.596 & $\mathrm{P}<0.001$ & -0.7895 & 0.0017 & & 0.0058 & 0.0143 & & & & \\
\hline & & & & $\mathrm{P}<0.001$ & & $\mathrm{P}=0.035$ & $\mathrm{P}<0.001$ & & & & \\
\hline \multirow{2}{*}{$\begin{array}{l}\text { Forest- } \\
\text { interior } \\
\text { Richness }\end{array}$} & 0.512 & $\mathrm{P}<0.001$ & -0.5153 & & & 0.0097 & 0.0074 & & & -0.0129 & -0.0267 \\
\hline & & & & & & $\mathrm{P}<0.001$ & $\mathrm{P}=0.006$ & & & $\mathrm{P}=0.008$ & 0.015 \\
\hline $\begin{array}{l}\text { Forest- } \\
\text { interior }\end{array}$ & 0.464 & $\mathrm{P}<0.001$ & -0.7104 & & & 0.0120 & 0.0089 & & & -0.0147 & -0.0334 \\
\hline Abundance & & & & & & $\mathrm{P}=0.001$ & $\mathrm{P}=0.013$ & & & $\mathrm{P}=0.022$ & $\mathrm{P}=0.022$ \\
\hline
\end{tabular}

* All dependent variables were square-root transformed in regression analyses. 
TABLE 4. Final regression models, reported with coefficients and partial F-statistic significance levels for included variables for greenways in Raleigh and Cary, NC during fall migration (2004). Significance levels set at $\alpha=0.05$ for variable inclusion in models.

\begin{tabular}{|c|c|c|c|c|c|c|c|c|}
\hline \multirow[b]{2}{*}{$\begin{array}{l}\text { Dependent } \\
\text { Variable* }\end{array}$} & \multirow[b]{2}{*}{$\begin{array}{c}\text { Model } \\
\mathrm{R}^{2}\end{array}$} & \multirow[b]{2}{*}{ Model P } & \multirow[b]{2}{*}{ Intercept } & \multirow[b]{2}{*}{$\begin{array}{c}\text { Forested } \\
\text { Width }\end{array}$} & \multicolumn{3}{|c|}{ Greenway Composition and Structure } & \multirow{2}{*}{$\begin{array}{c}\text { Adjacent Land Use } \\
\text { Building } \\
\text { Cover } \\
\end{array}$} \\
\hline & & & & & $\begin{array}{c}\text { Canopy } \\
\text { Cover }\end{array}$ & $\begin{array}{c}\text { Canopy } \\
\text { Height }\end{array}$ & $\begin{array}{l}\text { Shrub } \\
\text { Cover }\end{array}$ & \\
\hline \multirow{2}{*}{$\begin{array}{l}\text { Migrant } \\
\text { Richness }\end{array}$} & 0.363 & $\mathrm{P}<0.001$ & 0.7667 & 0.0018 & -0.0095 & & 0.1038 & \\
\hline & & & & $\mathrm{P}=0.001$ & $\mathrm{P}=0.003$ & & $\mathrm{P}=0.046$ & \\
\hline \multirow{2}{*}{$\begin{array}{l}\text { Migrant } \\
\text { Abundance }\end{array}$} & 0.305 & $\mathrm{P}<0.001$ & 1.2735 & 0.0024 & -0.0111 & & & \\
\hline & & & & $\mathrm{P}<0.001$ & $\mathrm{P}=0.004$ & & & \\
\hline \multirow{2}{*}{$\begin{array}{l}\text { Field-edge } \\
\text { Richness }\end{array}$} & 0.324 & $\mathrm{P}<0.001$ & 0.8274 & 0.0018 & -0.0088 & & & \\
\hline & & & & $\mathrm{P}<0.001$ & $\mathrm{P}=0.002$ & & & \\
\hline \multirow{2}{*}{$\begin{array}{l}\text { Field-edge } \\
\text { Abundance }\end{array}$} & 0.354 & $\mathrm{P}<0.001$ & 1.1245 & 0.0022 & -0.0122 & & & \\
\hline & & & & $\mathrm{P}<0.001$ & $\mathrm{P}<0.001$ & & & \\
\hline \multirow{2}{*}{$\begin{array}{l}\text { Forest-edge } \\
\text { Richness }\end{array}$} & 0.134 & $\mathrm{P}=0.011$ & 0.4326 & & & & & -0.0168 \\
\hline & & & & & & & & $\mathrm{P}=0.011$ \\
\hline \multirow{2}{*}{$\begin{array}{l}\text { Forest-edge } \\
\text { Abundance }\end{array}$} & 0.129 & $\mathrm{P}=0.013$ & 0.4539 & & & & & -0.0174 \\
\hline & & & & & & & & $\mathrm{P}=0.013$ \\
\hline \multirow{2}{*}{$\begin{array}{l}\text { Forest-interior } \\
\text { Richness }\end{array}$} & 0.211 & $\mathrm{P}=0.006$ & -0.5106 & & & 0.0041 & 0.0690 & \\
\hline & & & & & & $\mathrm{P}=0.048$ & $\mathrm{P}=0.039$ & \\
\hline \multirow{2}{*}{$\begin{array}{l}\text { Forest-interior } \\
\text { Abundance }\end{array}$} & 0.125 & $\mathrm{P}=0.015$ & -0.4246 & & & 0.0059 & & \\
\hline & & & & & & $\mathrm{P}=0.015$ & & \\
\hline
\end{tabular}

* All dependent variables were square-root transformed in regression analyses. 


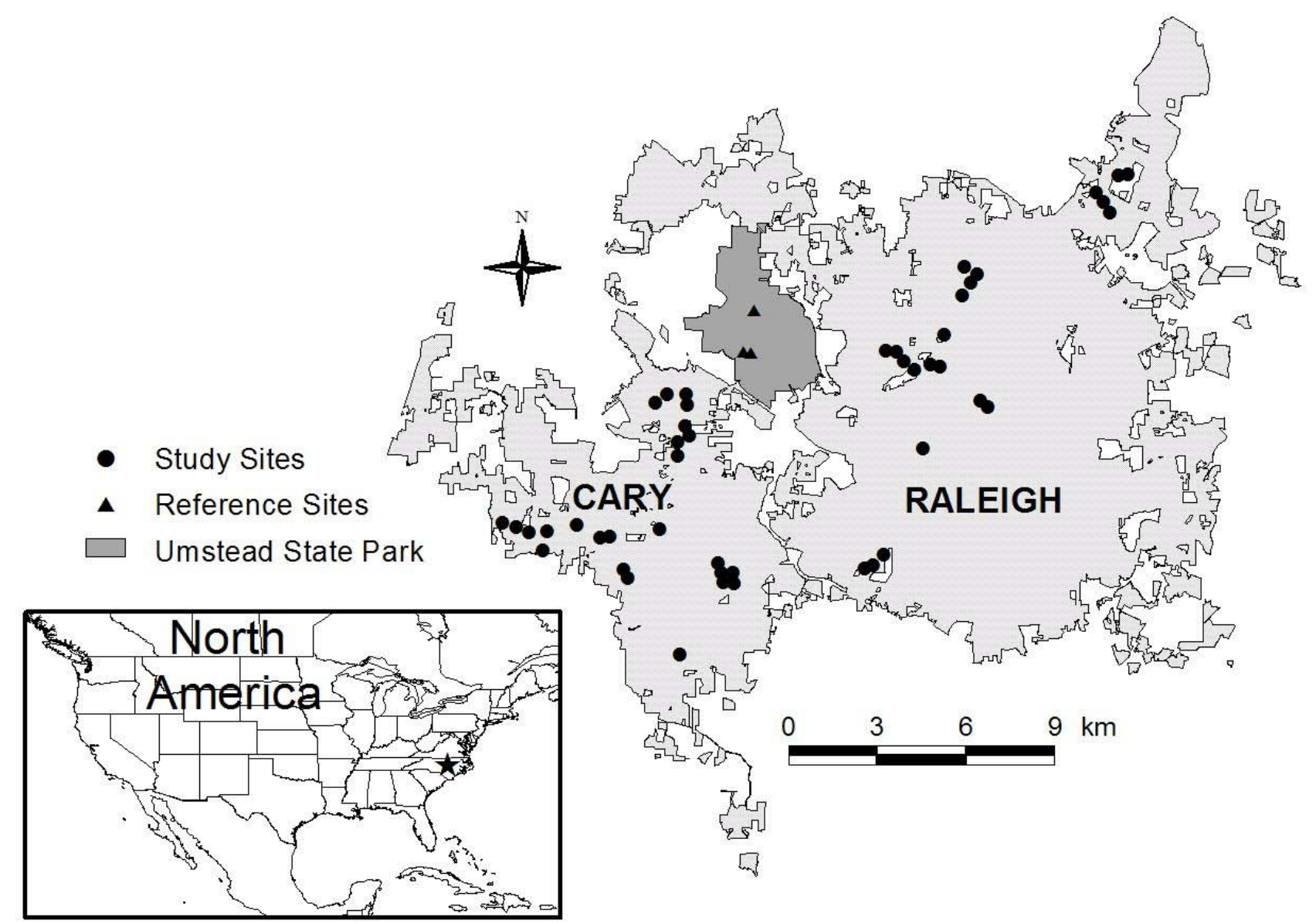

FIG. 1. Greenway segment and reference site locations in Raleigh and Cary, North Carolina, USA. 


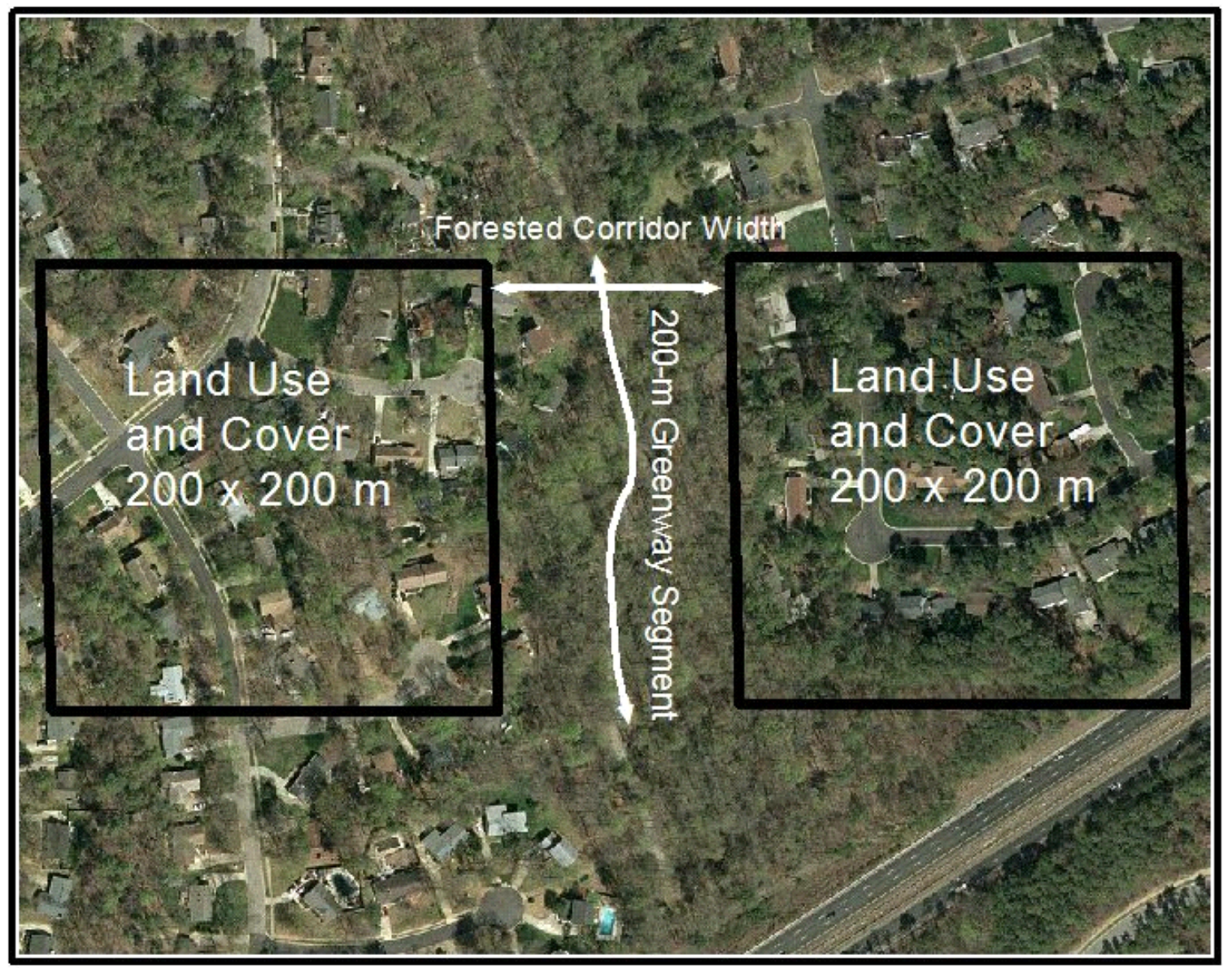

FIG. 2. Forested corridor width and adjacent land use were determined for each 200-m greenway segment in ArcGIS. Land cover variables were measured in two 200-m x 200$m$ areas on either side of the forested corridor. 


\section{$\square 0-75 m \quad \square 76-150 m \quad \square>150 m \quad \square$ Reference}

A

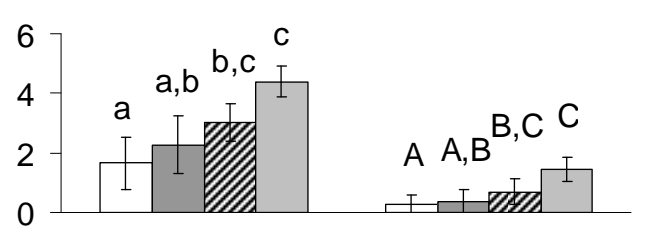

C

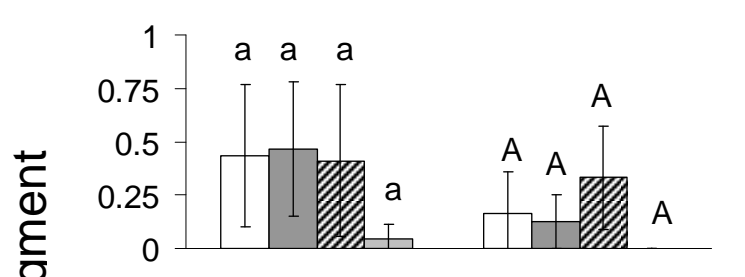

E

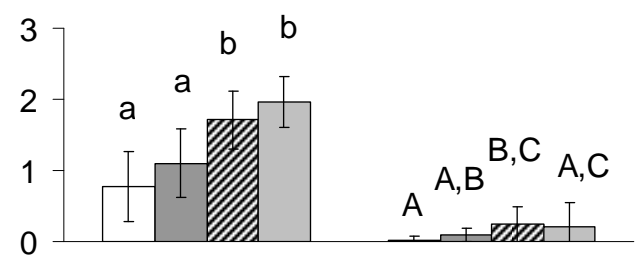

G

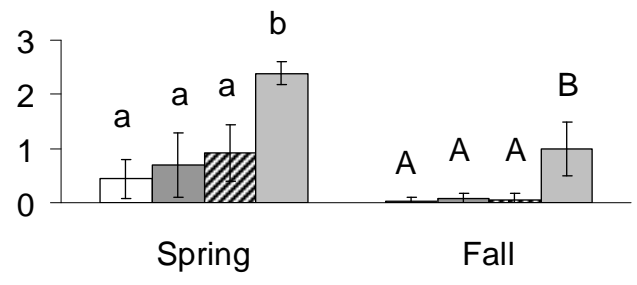

B

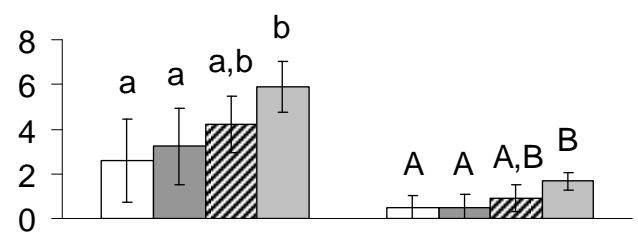

D

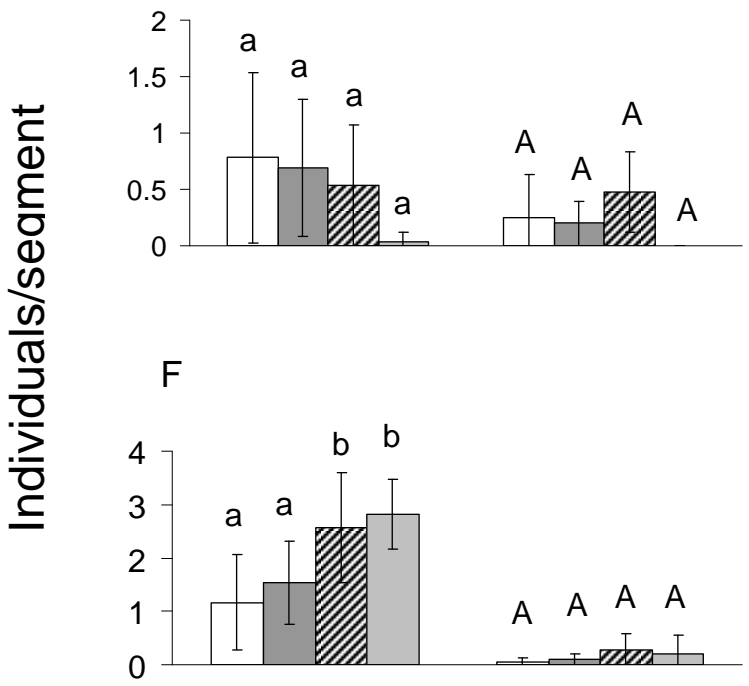

$\mathrm{H}$

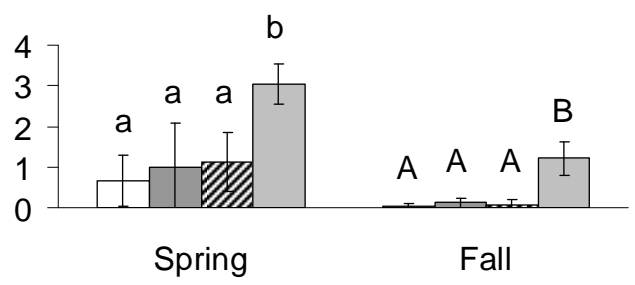

FIG. 3. Mean richness and abundance of migrating birds using reference sites in Umstead State Park and Raleigh and Cary, NC greenways of differing forested corridor width categories during spring (2004-2005) and fall (2004) shown with standard deviation bars. (A) migrant species richness, (B) migrant abundance, (C) field-edge species richness, (D) field-edge abundance, (E) forest-edge species richness, (F) forest-edge abundance, $(\mathrm{G})$ forest-interior species richness, $(\mathrm{H})$ forest-interior abundance. Richness and abundance calculated as average number of migrant bird species and individuals detected per survey per segment per category. Bars with the same letter are not significantly different $(\mathrm{P}<0.05$, Tukey). 
CHAPTER 3: APPENDICES 
APPENDIX 1. Winter resident and year-round resident species occurrences in greenways and reference sites presented by adjacent land use and width categories. Each cell contains the number of segments in the corresponding category in which the species was recorded during spring migration (S) (2004-2005) or fall migration (F) (2004). Adjacent land use categories are: LDR, low-density residential ( $\leq 7.5$ lots/hectare); HDR, high-density residential ( $>7.5$ lots/hectare); OFC, Office/Institutional. Reference segments are indicated by REF.

\begin{tabular}{|c|c|c|c|c|c|c|c|c|c|c|c|c|c|c|}
\hline \multirow[b]{3}{*}{ Guild/Species } & \multicolumn{6}{|c|}{ Adjacent Land Use } & \multicolumn{6}{|c|}{ Forested Corridor Width (m) } & & \\
\hline & \multicolumn{2}{|c|}{$\begin{array}{c}\text { LDR } \\
(19) \\
\end{array}$} & \multicolumn{2}{|c|}{$\begin{array}{l}\text { HDR } \\
(12)\end{array}$} & \multicolumn{2}{|c|}{$\begin{array}{c}\text { OI } \\
(16)\end{array}$} & \multicolumn{2}{|c|}{$\begin{array}{l}0-75 \\
(10)\end{array}$} & \multicolumn{2}{|c|}{$\begin{array}{c}76-150 \\
(23) \\
\end{array}$} & \multicolumn{2}{|c|}{$\begin{array}{c}>150 \\
(14) \\
\end{array}$} & \multicolumn{2}{|c|}{$\begin{array}{c}\text { REF } \\
(3)\end{array}$} \\
\hline & $\mathrm{S}$ & $\mathrm{F}$ & $\mathrm{S}$ & $\mathrm{F}$ & $\mathrm{S}$ & $\mathrm{F}$ & $\mathrm{S}$ & $\mathrm{F}$ & $\mathrm{S}$ & $\mathrm{F}$ & $\mathrm{S}$ & $\mathrm{F}$ & $\mathrm{S}$ & $\mathrm{F}$ \\
\hline \multicolumn{15}{|l|}{ Winter Residents } \\
\hline Brown Creeper (Certhia americana) & 1 & & & & & & & & 1 & & & & & \\
\hline Cedar Waxwing (Bombycilla cedrorum) & 13 & & 8 & & 14 & & 8 & & 17 & & 10 & & & \\
\hline Dark-eyed Junco (Junco hyemalis) & 1 & & & & & & & & 1 & & & & & \\
\hline Golden-crowned Kinglet (Regulus satrapa) & & 1 & & 3 & & & & & & 3 & & 1 & & 1 \\
\hline Hermit Thrush (Catharus guttatus) & 4 & 3 & 1 & & 2 & 1 & 1 & & 6 & 3 & & 1 & & \\
\hline Ruby-crowned Kinglet (Regulus calendula) & 18 & 10 & 12 & 6 & 15 & 8 & 10 & 4 & 22 & 13 & 13 & 7 & 2 & 2 \\
\hline White-throated Sparrow (Zonotrichia albicollis) & 19 & 12 & 12 & 5 & 15 & 12 & 10 & 8 & 23 & 14 & 13 & 7 & 2 & 1 \\
\hline Yellow-bellied Sapsucker (Sphyrapicus varius) & & 4 & & 1 & & 3 & & 4 & & 3 & & 1 & & 1 \\
\hline Yellow-rumped Warbler (Dendroica coronata) & 19 & 19 & 12 & 12 & 16 & 16 & 10 & 8 & 23 & 6 & 14 & 3 & 3 & 3 \\
\hline
\end{tabular}




\begin{tabular}{|c|c|c|c|c|c|c|c|c|c|c|c|c|c|c|c|}
\hline \multirow[b]{3}{*}{ Guild/Species } & \multirow{3}{*}{ Number of sites } & \multicolumn{6}{|c|}{ Adjacent Land Use } & \multicolumn{6}{|c|}{ Forested Corridor Width (m) } & & \\
\hline & & \multicolumn{2}{|c|}{$\begin{array}{c}\text { LDR } \\
(19) \\
\end{array}$} & \multicolumn{2}{|c|}{$\begin{array}{c}\text { HDR } \\
(12) \\
\end{array}$} & \multicolumn{2}{|c|}{$\begin{array}{c}\text { OI } \\
(16) \\
\end{array}$} & \multicolumn{2}{|c|}{$\begin{array}{l}0-75 \\
(10) \\
\end{array}$} & \multicolumn{2}{|c|}{$\begin{array}{c}76-150 \\
(23) \\
\end{array}$} & \multicolumn{2}{|c|}{$\begin{array}{c}>150 \\
(14) \\
\end{array}$} & \multicolumn{2}{|c|}{$\begin{array}{l}\text { REF } \\
(3) \\
\end{array}$} \\
\hline & & $\mathrm{S}$ & $\mathrm{F}$ & $\mathrm{S}$ & $\mathrm{F}$ & $\mathrm{S}$ & $\mathrm{F}$ & $\mathrm{S}$ & $\mathrm{F}$ & $\mathrm{S}$ & $\mathrm{F}$ & $\mathrm{S}$ & $\mathrm{F}$ & $\mathrm{S}$ & $\mathrm{F}$ \\
\hline \multicolumn{16}{|l|}{ Year-round Residents } \\
\hline American Crow (Corvus brachyrhynchos) & & 10 & 7 & 3 & 3 & 3 & 6 & 4 & 3 & 10 & 9 & 2 & 4 & & \\
\hline American Goldfinch (Carduelis tristis) & & 19 & 18 & 12 & 9 & 16 & 13 & 10 & 7 & 23 & 21 & 14 & 12 & 3 & 1 \\
\hline American Robin (Turdus migratorius) & & 19 & 16 & 12 & 11 & 16 & 10 & 10 & 9 & 23 & 16 & 14 & 12 & & \\
\hline Barred Owl (Strix varia) & & 1 & & & & & & 1 & & & & & & & \\
\hline Belted Kingfisher (Ceryle alcyon) & & 5 & 1 & 5 & 1 & 4 & & 2 & & 6 & 1 & 6 & 1 & 2 & \\
\hline Black Vulture (Coragyps atratus) & & & & & & 1 & & & & 1 & & & & & \\
\hline Blue Jay (Cyanocitta cristata) & & 18 & 14 & 9 & 8 & 12 & 14 & 9 & 8 & 21 & 18 & 9 & 10 & 1 & \\
\hline Brown Thrasher (Toxostoma rufum) & & 13 & 7 & 8 & 7 & 12 & 6 & 9 & 5 & 15 & 7 & 9 & 8 & & \\
\hline Brown-headed Cowbird (Molothrus ater) & & 18 & & 11 & & 13 & & 8 & & 21 & & 13 & & 3 & \\
\hline Brown-headed Nuthatch (Sitta pusilla) & & 6 & 7 & 9 & 6 & 11 & 7 & 6 & 4 & 13 & 10 & 7 & 6 & & \\
\hline Canada Goose (Branta canadensis) & & & & 1 & & 3 & & 2 & & 1 & & 1 & & & \\
\hline Carolina Chickadee (Poecile carolinensis) & & 19 & 19 & 12 & 12 & 16 & 16 & 10 & 10 & 23 & 23 & 14 & 14 & 3 & 3 \\
\hline Carolina Wren (hryothorus ludovicianus) & & 19 & 19 & 12 & 12 & 16 & 16 & 10 & 10 & 23 & 23 & 14 & 14 & 3 & 3 \\
\hline Chipping Sparrow (Spizella passerina) & & 6 & & 4 & & 7 & 1 & 5 & & 10 & 1 & 2 & & & \\
\hline Common Grackle (Quiscalus quiscula) & & 13 & 4 & 10 & & 8 & 2 & 8 & & 15 & 4 & 8 & 2 & 2 & \\
\hline Downy Woodpecker (Picoides pubescens) & & 17 & 15 & 12 & 11 & 9 & 9 & 6 & 4 & 20 & 19 & 12 & 12 & 2 & 2 \\
\hline
\end{tabular}




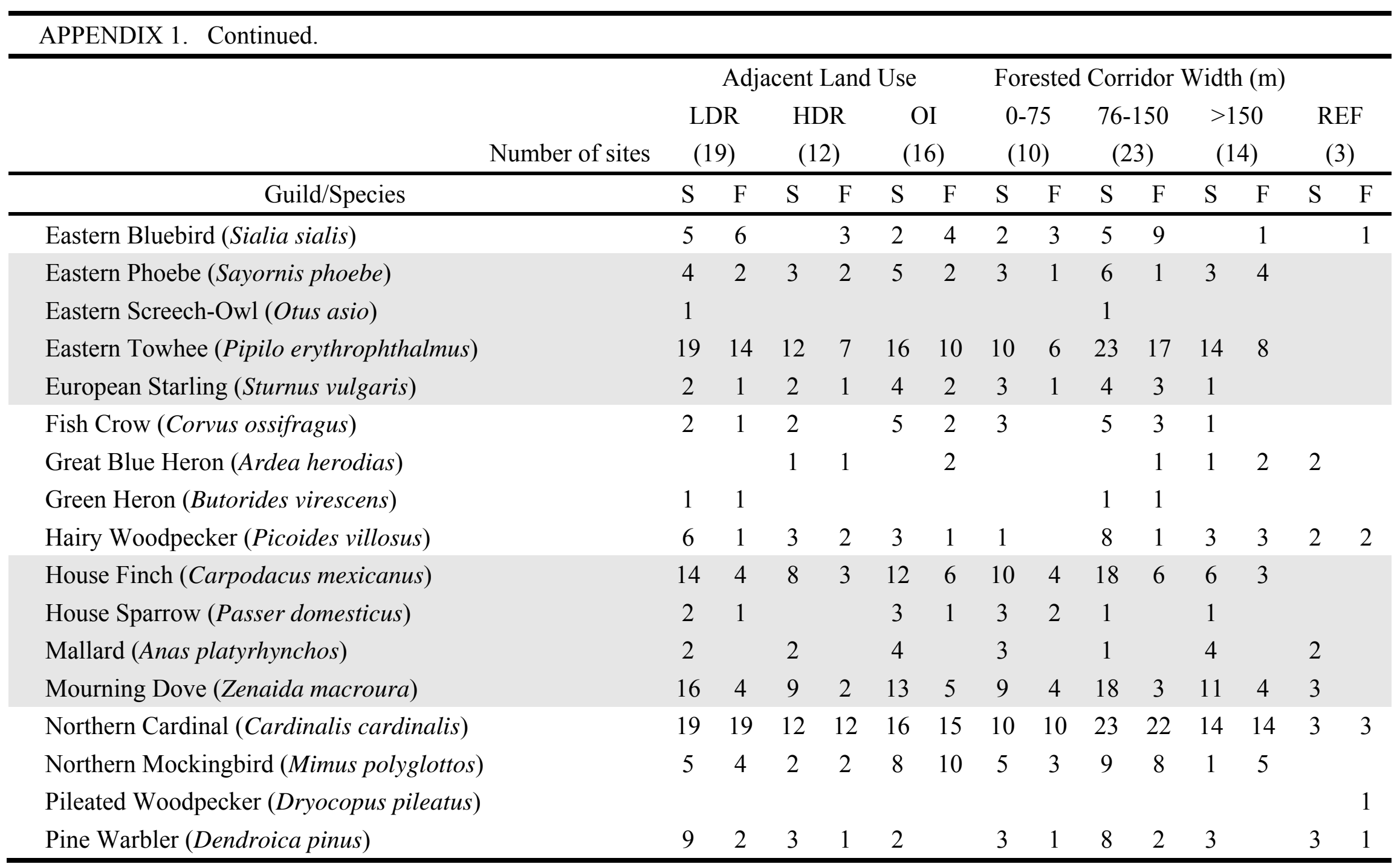




\begin{tabular}{|c|c|c|c|c|c|c|c|c|c|c|c|c|c|c|}
\hline \multirow[b]{3}{*}{ Guild/Species } & \multicolumn{6}{|c|}{ Adjacent Land Use } & \multicolumn{6}{|c|}{ Forested Corridor Width (m) } & & \\
\hline & \multicolumn{2}{|c|}{$\begin{array}{l}\text { LDR } \\
\text { (19) }\end{array}$} & \multicolumn{2}{|c|}{$\begin{array}{l}\text { HDR } \\
(12)\end{array}$} & \multicolumn{2}{|c|}{$\begin{array}{c}\text { OI } \\
(16)\end{array}$} & \multicolumn{2}{|c|}{$\begin{array}{l}0-75 \\
(10)\end{array}$} & \multicolumn{2}{|c|}{$\begin{array}{c}76-150 \\
(23)\end{array}$} & \multicolumn{2}{|c|}{$\begin{array}{l}>150 \\
(14)\end{array}$} & \multicolumn{2}{|c|}{$\begin{array}{l}\text { REF } \\
(3)\end{array}$} \\
\hline & $\mathrm{S}$ & $\mathrm{F}$ & $\mathrm{S}$ & $\mathrm{F}$ & $\mathrm{S}$ & $\mathrm{F}$ & $\mathrm{S}$ & $\mathrm{F}$ & $\mathrm{S}$ & $\mathrm{F}$ & $\mathrm{S}$ & $\mathrm{F}$ & $\mathrm{S}$ & $\mathrm{F}$ \\
\hline Red-bellied Woodpecker (Melanerpes carolinus) & 19 & 19 & 12 & 12 & 13 & 14 & 8 & 10 & 23 & 21 & 13 & 14 & 3 & 3 \\
\hline Red-headed Woodpecker (Melanerpes erythrocephalus) & 4 & 1 & 2 & & 2 & 1 & 1 & & 6 & 1 & 1 & 1 & 1 & \\
\hline Red-shouldered Hawk (Buteo lineatus) & 8 & 1 & 4 & 1 & 1 & 4 & 1 & & 10 & 5 & 2 & 1 & & \\
\hline Red-tailed Hawk (Buteo jamaicensis) & 1 & & & & & & & & & & 1 & & & \\
\hline Song Sparrow (Melospiza melodia) & & & & & 2 & 1 & 1 & 1 & 1 & & & & & \\
\hline Tufted Titmouse (Baeolophus bicolor) & 19 & 19 & 12 & 12 & 16 & 15 & 10 & 10 & 23 & 22 & 14 & 14 & 3 & 2 \\
\hline Turkey Vulture (Cathartes aura) & 1 & & & & & 1 & & & & 1 & 1 & & & \\
\hline White-breasted Nuthatch (Sitta carolinensis) & 17 & 15 & 7 & 11 & 9 & 12 & 7 & 7 & 17 & 20 & 9 & 11 & 1 & 2 \\
\hline Yellow-shafted Flicker (Colaptes auratus) & 10 & 12 & 7 & 7 & 5 & 9 & 5 & 4 & 11 & 15 & 6 & 9 & & 1 \\
\hline
\end{tabular}


APPENDIX 2. Species recorded in each greenway segment and reference site during migration surveys; ${ }^{\mathrm{s}}=$ recorded during spring only; ${ }^{\mathrm{f}}=$ species recorded during fall only.

\section{Alleghany 1 Average width: $233.4 \mathrm{~m} \quad$ Adjacent land use: OI} American $\mathrm{Crow}^{\mathrm{s}}$, American Goldfinch, American Redstart ${ }^{\mathrm{s}}$, American Robin, Black-andwhite Warbler ${ }^{\mathrm{s}}$, Black-throated Blue Warbler ${ }^{\mathrm{s}}$, Blue-gray Gnatcatcher ${ }^{\mathrm{s}}$, Blue Jay ${ }^{\mathrm{f}}$, Brownheaded Cowbird ${ }^{\mathrm{s}}$, Brown-headed Nuthatch, Brown Thrashers, Carolina Chickadee, Carolina Wren, Cedar Waxwing ${ }^{\mathrm{s}}$, Common Grackle ${ }^{\mathrm{f}}$, Downy Woodpecker ${ }^{\mathrm{f}}$, Eastern Phoebe, Eastern Towhee ${ }^{\mathrm{s}}$, Tufted Titmouse, Eastern Wood-Pewee, Gray Catbird, Great Crested Flycatchers, Hairy Woodpecker, Hooded Warblers, House Finch, Kentucky Warblers, Mourning Dove, Northern Cardinal, Northern Parulas, Ovenbird ${ }^{\mathrm{s}}$, Red-bellied Woodpecker, Red-eyed Vireos, Ruby-crowned Kinglet, Ruby-throated Hummingbird, White-breasted Nuthatch ${ }^{\mathrm{f}}$, White-eyed Vireos ${ }^{\mathrm{s}}$, Wood Thrush, White-throated Sparrow, Yellow-rumped Warbler, Northern Flicker

\section{Alleghany $2 \quad$ Average width: $366.7 \mathrm{~m} \quad$ Adjacent land use: LDR}

Acadian Flycatcher , American Goldfinch, American Robin, Belted Kingfisher, Blue-gray Gnatcatchers, Black-and-white Warblers, Blue Jay, Brown-headed Cowbirds, Black-throated Blue Warbler ${ }^{\mathrm{s}}$, Brown-headed Nuthatch, Brown Thrasher ${ }^{\mathrm{f}}$, Carolina Chickadee, Carolina Wren, Cedar Waxwing ${ }^{\mathrm{s}}$, Common Grackles, Common Yellowthroat, Downy Woodpecker, Eastern Phoebe ${ }^{\mathrm{f}}$, Eastern Towhee, Tufted Titmouse, European Starlings, Gray Catbird ${ }^{\mathrm{f}}$, Great Crested Flycatcher ${ }^{\mathrm{s}}$, Hairy Woodpecker ${ }^{\mathrm{s}}$, Hermit Thrush ${ }^{\mathrm{f}}$, Hooded Warbler ${ }^{\mathrm{s}}$ House Finch, Indigo Bunting ${ }^{\mathrm{s}}$, Mourning Doves, Northern Cardinal, Northern Mockingbird ${ }^{\mathrm{f}}$, Northern Parula $^{\mathrm{s}}$, Northern Waterthrush ${ }^{\mathrm{s}}$, Ovenbird ${ }^{\mathrm{s}}$, Red-bellied Woodpecker, Red-eyed Vireo ${ }^{\mathrm{s}}$, Redtailed Hawk $k^{\mathrm{s}}$, Ruby-crowned Kinglet, Ruby-throated Hummingbird, Turkey Vulture, Unknown Warbler ${ }^{f}$, White-breasted Nuthatch, White-eyed Vireo ${ }^{\mathrm{s}}$, White-throated Sparrow, Wood Thrush ${ }^{\mathrm{s}}$ Yellow-rumped Warbler ${ }^{\mathrm{s}}$, Yellow Warbler ${ }^{\mathrm{s}}$

\section{Beaverdam Average width: $43.3 \mathrm{~m} \quad$ Adjacent land use: HDR}

American Goldfinch ${ }^{\mathrm{s}}$, American Redstart ${ }^{\mathrm{s}}$, American Robin, Blue-gray, Gnatcatcher ${ }^{\mathrm{s}}$, Blue Jay, Brown-headed Cowbird ${ }^{\mathrm{s}}$, Brown-headed Nuthatch, Brown Thrasher, Carolina Chickadee, Carolina Wren , Cedar Waxwings, Chipping Sparrow ${ }^{\mathrm{s}}$, Common Grackle, Downy Woodpecker ${ }^{\mathrm{s}}$, Eastern Towhee ${ }^{\mathrm{s}}$, Tufted Titmouse, Gray Catbird ${ }^{\mathrm{s}}$, House Finch ${ }^{\mathrm{s}}$, House Wren ${ }^{\mathrm{s}}$, Magnolia Warbler $\mathrm{f}^{\mathrm{f}}$, Mourning Dove, Northern Cardinal, Northern Mockingbird ${ }^{\mathrm{s}}$, Northern Parula ${ }^{\mathrm{s}}$, Red-bellied Woodpecker, Ruby-crowned Kinglet, Rubythroated Hummingbird ${ }^{\mathrm{s}}$, Unknown Warbler ${ }^{\mathrm{f}}$, White-breasted Nuthatch, White-throated Sparrow, Wood Thrush ${ }^{\mathrm{s}}$, Yellow-bellied Sapsucker ${ }^{\mathrm{f}}$, Yellow-rumped Warbler, Northern Flicker $^{\mathrm{f}}$

Black Creek $1 \quad$ Average width: $125.3 \mathrm{~m} \quad$ Adjacent land use: OI Acadian Flycatchers, American Goldfinch, American Robin ${ }^{\mathrm{s}}$, Belted Kingfisher ${ }^{\mathrm{s}}$, Blackpoll Warbler , Blue-gray Gnatcatcher ${ }^{\mathrm{s}}$, Blue Jay, Brown-headed Cowbird ${ }^{\mathrm{s}}$, Carolina Chickadee, Carolina Wren, Cedar Waxwing ${ }^{\mathrm{s}}$, Common Grackles , Common Yellowthroat ${ }^{\mathrm{s}}$, Downy 
Woodpecker ${ }^{\mathrm{s}}$, Eastern Phoebe ${ }^{\mathrm{s}}$, Eastern Towhee ${ }^{\mathrm{s}}$, Tufted Titmouse, Gray Catbird ${ }^{\mathrm{s}}$, Hermit Thrush $^{\text {s, }}$ Mallard ${ }^{\text {s, }}$ Mourning Doves, Northern Cardinal', Northern Parulas, Red-bellied Woodpeckers , Red-eyed Vireos, Red-shouldered Hawk, Ruby-crowned Kinglet, Scarlet Tanager ${ }^{\mathrm{s}}$, Summer Tanager ${ }^{\mathrm{s}}$, White-breasted Nuthatch, White-eyed Vireo ${ }^{\mathrm{s}}$, White-throated Sparrow $^{\text {s }}$, Wood Thrush ${ }^{\mathrm{s}}$, Yellow-rumped Warbler ${ }^{\mathrm{s}}$

\section{Black Creek 2 Average width: 230.1m Adjacent land use: OI} Acadian Flycatcher ${ }^{\mathrm{s}}$, American Goldfinch's, American Redstarts, American Robin's, Blackand-white Warblers, Black-throated Blue Warblers, Blue-gray Gnatcatchers, Blue-headed Vireo $^{\text {s, Blue Jay, Belted Kingfisher }}$, Brown-headed Nuthatch, Brown Thrasher ${ }^{\mathrm{s}}$, Carolina Chickadee, Carolina Wren, Cedar Waxwing ${ }^{\mathrm{s}}$, Downy Woodpecker ${ }^{\mathrm{f}}$, Eastern Phoebe ${ }^{\mathrm{s}}$, Eastern Towhee, Tufted Titmouse, Gray Catbird ${ }^{\mathrm{s}}$, Louisiana Waterthrush ${ }^{\mathrm{s}}$, Northern Cardinal, Northern Parula ${ }^{\mathrm{s}}$, Ovenbird ${ }^{\mathrm{s}}$, Pine Warbler ${ }^{\mathrm{s}}$, Red-bellied Woodpecker, Red-eyed Vireo ${ }^{\mathrm{s}}$, Ruby-crowned Kinglet ${ }^{\mathrm{s}}$, Ruby-throated Hummingbird, Summer Tanagers ${ }^{\mathrm{s}}$, White-breasted Nuthatch, Worm-eating Warbler ${ }^{\mathrm{s}}$, Yellow-rumped Warbler ${ }^{\mathrm{s}}$, Northern Flicker ${ }^{\mathrm{f}}$, Yellowthroated Warbler ${ }^{\mathrm{s}}$

\section{Black Creek 3 Average width: $174.3 \mathrm{~m} \quad$ Adjacent land use: LDR}

Acadian Flycatcher ${ }^{\mathrm{s}}$, American Goldfinch, American Redstarts, American Robin ${ }^{\mathrm{s}}$, Black-andwhite Warblers, Blackpoll Warblers, Black-throated Blue Warblers, Blue-gray Gnatcatcher, Blue Jay, Brown-headed Cowbird, Carolina Chickadee, Carolina Wren, Cedar Waxwing ${ }^{\text {s, }}$ Common Grackle ${ }^{\mathrm{f}}$, Common Yellowthroats ${ }^{\mathrm{s}}$, Downy Woodpecker ${ }^{\mathrm{s}}$, Eastern Towhee ${ }^{\mathrm{s}}$, Tufted Titmouse, Gray Catbirds', Great-crested Flycatcher ${ }^{\mathrm{s}}$, Indigo Bunting, Louisiana Waterthrush' Mallard $^{\mathrm{s}}$, Mourning Dove, Northern Cardinal, Northern Parula ${ }^{\mathrm{s}}$, Northern Waterthrush's ${ }^{\mathrm{s}}$, Pine Warbler ${ }^{\mathrm{s}}$, Red-bellied Woodpecker, Red-eyed Vireos, Rose-breasted Grosbeak', Rubycrowned Kinglet, Red-shouldered Hawk ${ }^{\mathrm{s}}$, Ruby-crowned Kinglet ${ }^{\mathrm{f}}$, Ruby-throated Hummingbird, Scarlet Tanager ${ }^{\mathrm{s}}$, White-breasted Nuthatch ${ }^{\mathrm{s}}$, White-eyed Vireo ${ }^{\mathrm{s}}$, Whitethroated Sparrow ${ }^{\mathrm{s}}$, Northern Flicker ${ }^{\mathrm{f}}$, Yellow-rumped Warbler ${ }^{\mathrm{s}}$,

\section{Black Creek 4 Average width: $89.3 \mathrm{~m} \quad$ Adjacent land use: HDR}

Acadian Flycatcher ${ }^{\mathrm{s}}$, American Goldfinch, American Redstart ${ }^{\mathrm{s}}$, American Robin, Black-andwhite Warbler's, Black-throated Blue Warblers, Blue-gray Gnatcatcher ${ }^{\mathrm{s}}$, Blue Jay ${ }^{\mathrm{s}}$, Brownheaded Cowbird ${ }^{\mathrm{s}}$, Brown-headed Nuthatch, Carolina Chickadee, Carolina Wren, Cedar Waxwing ${ }^{\mathrm{s}}$, Common Grackles, Common Yellowthroat ${ }^{\mathrm{s}}$, Downy Woodpecker, Eastern Bluebird $^{\mathrm{f}}$, Eastern Phoebe ${ }^{\mathrm{s}}$, Eastern Towhee, Tufted Titmouse, Golden-crowned Kinglet ${ }^{\mathrm{f}}$, Hooded Warblers, Indigo Bunting ${ }^{\mathrm{s}}$, Louisiana Waterthrush ${ }^{\mathrm{s}}$, Northern Cardinal, Northern Parula ${ }^{\mathrm{s}}$, Orchard Oriole ${ }^{\mathrm{s}}$, Ovenbird ${ }^{\mathrm{s}}$, Red-bellied Woodpecker, Red-eyed Vireo ${ }^{\mathrm{s}}$, Redshouldered Hawk's , Rose-breasted Grosbeaks, Ruby-crowned Kinglet, Ruby-throated Hummingbird, White-eyed Vireo ${ }^{\mathrm{s}}$, White-breasted Nuthatch ${ }^{\mathrm{f}}$, White-throated Sparrow ${ }^{\mathrm{s}}$, Wood Thrush ${ }^{\mathrm{s}}$, Yellow-rumped Warbler ${ }^{\mathrm{s}}$, Northern Flicker ${ }^{\mathrm{f}}$, Yellow Warbler ${ }^{\mathrm{s}}$

\section{Black Creek 5 Average width: $440.1 \mathrm{~m} \quad$ Adjacent land use: HDR} Acadian Flycatcher ${ }^{\mathrm{s}}$, American Goldfinch, American Redstart ${ }^{\mathrm{s}}$, American Robin, Black-andwhite Warblers, Black-throated Blue Warblers, Blue Jay, Blue-gray Gnatcatcher ${ }^{\text {s }}$, Brown- 
headed Cowbird ${ }^{\mathrm{s}}$, Carolina Chickadee, Carolina Wren, Common Grackle ${ }^{\mathrm{s}}$, Common Yellowthroat, Downy Woodpecker, Eastern Phoebe ${ }^{\mathrm{f}}$, Eastern Towhee ${ }^{\mathrm{s}}$, Tufted Titmouse, Gray Catbird, Great-crested Flycatchers, Mourning Doves ${ }^{\mathrm{s}}$, Northern Cardinal, Northern Parulas, Ovenbird $^{\mathrm{s}}$, Red-bellied Woodpecker, Red-eyed Vireo ${ }^{\mathrm{s}}$, Ruby-crowned Kinglet ${ }^{\mathrm{s}}$, Ruby-throated Hummingbird ${ }^{\mathrm{s}}$, Scarlet Tanagers, White-breasted Nuthatch, White-eyed Vireo $^{\text {s, }}$, White-throated Sparrow ${ }^{\mathrm{s}}$, Wood Thrush's, Yellow-rumped Warbler ${ }^{\mathrm{s}}$, Northern Flicker

\section{Black Creek 6 Average width: 104.9 m Adjacent land use: HDR}

Acadian Flycatcher ${ }^{\mathrm{s}}$, American Goldfinch, American Redstart ${ }^{\mathrm{s}}$, American Robin ${ }^{\mathrm{s}}$, Black-andwhite Warblers, Blue-gray Gnatcatchers, Brown-headed Nuthatch's, Blue Jay ${ }^{\mathrm{s}}$, Blackpoll Warbler $^{\mathrm{s}}$, Brown-headed Cowbird ${ }^{\mathrm{s}}$, Brown Thrasher, Carolina Chickadee, Carolina Wren, Canada Warblers, Cedar Waxwing ${ }^{\mathrm{s}}$, Chipping Sparrows , Common Grackles , Common Yellowthroat $^{\mathrm{s}}$, Downy Woodpeckers ${ }^{\mathrm{s}}$, Eastern Towhee, Tufted Titmouse, Fish Crow ${ }^{\mathrm{s}}$, Great Crested Flycatcher ${ }^{\mathrm{s}}$, Gray Catbird, Hairy Woodpecker, House Finch, House Wren ${ }^{\mathrm{s}}$, Mourning Doves, Northern Cardinal, Pine Warbler, Red-bellied Woodpecker, Ruby-crowned Kinglet $^{\mathrm{s}}$, Red-eyed Vireo ${ }^{\mathrm{s}}$, Red-headed Woodpecker ${ }^{\mathrm{s}}$, Red-shouldered Hawk ${ }^{\mathrm{s}}$, Ruby-throated Hummingbird $^{\mathrm{s}}$, White-breasted Nuthatch, White-eyed Vireos, Wood Thrush, White-throated Sparrow ${ }^{\mathrm{s}}$, Palm Warblers, Yellow-rumped Warblers, Northern Flicker

Crabtree $1 \quad$ Average width: $38.0 \mathrm{~m} \quad$ Adjacent land use: OI American Goldfinch, American Robin, Blackpoll Warbler ${ }^{\mathrm{s}}$, Blue-gray Gnatcatcher ${ }^{\mathrm{s}}$, Brown Thrasher ${ }^{\mathrm{s}}$, Brown-headed Nuthatch, Canada Gooses ${ }^{\mathrm{s}}$, Carolina Chickadee, Carolina Wren, Cedar Waxwings, Common Grackles, Common Yellowthroat ${ }^{\mathrm{s}}$, Eastern Towhee, European Starlings, Fish Crows , Gray Catbird, House Finch, House Sparrow, Mallard ${ }^{\mathrm{s}}$, Mourning Dove, Northern Cardinal, Northern Mockingbird, Prothonotary Warbler ${ }^{\mathrm{s}}$, Red-bellied Woodpecker ${ }^{\mathrm{f}}$, Ruby-crowned Kinglet ${ }^{\mathrm{s}}$, Ruby-throated Hummingbird ${ }^{\mathrm{s}}$, Song Sparrow ${ }^{\mathrm{f}}$, Tufted Titmouse, White-throated Sparrow, Yellow Warblers, Yellow-rumped Warbler

Crabtree 2 Average width: $32.4 \mathrm{~m} \quad$ Adjacent land use: OI

American Goldfinch ${ }^{\mathrm{s}}$, American Robin , Blue Jay, Blue-gray Gnatcatcher ${ }^{\mathrm{s}}$, Brown Thrasher ${ }^{\mathrm{s}}$, Brown-headed Cowbirds ${ }^{\mathrm{s}}$, Brown-headed Nuthatch, Canada Goose ${ }^{\mathrm{s}}$, Carolina Chickadee, Carolina Wren, Cedar Waxwings, Eastern Phoebes ${ }^{\mathrm{s}}$, Eastern Towhee ${ }^{\mathrm{s}}$, European Starling , Fish Crow $^{\mathrm{s}}$, Gray Catbird ${ }^{\mathrm{f}}$, House Finch, House Sparrow ${ }^{\mathrm{s}}$, Mourning Dove, Northern Cardinal, Northern Mockingbird, Red-bellied Woodpecker ${ }^{\mathrm{f}}$, Ruby-crowned Kinglet ${ }^{\mathrm{s}}$, Rubythroated Hummingbird ${ }^{\mathrm{s}}$, Song Sparrow ${ }^{\mathrm{s}}$, Tufted Titmouse, White-eyed Vireo ${ }^{\mathrm{s}}$, Whitethroated Sparrow, Yellow-rumped Warbler

Durant 1 Average width: $47.4 \mathrm{~m} \quad$ Adjacent land use: LDR American Crow, American Goldfinch, American Redstart ${ }^{\mathrm{s}}$, American Robin, Blackpoll Warbler ${ }^{\mathrm{s}}$, Black-throated Blue Warbler ${ }^{\mathrm{s}}$, Blue Jay, Brown-headed Nuthatch ${ }^{\mathrm{f}}$, Brown Thrasher, Brown-headed Cowbird ${ }^{\mathrm{s}}$, Carolina Chickadee, Carolina Wren, Cedar Waxwing ${ }^{\mathrm{s}}$, Chipping Sparrow ${ }^{\mathrm{s}}$, Common Grackles , Common Yellowthroat ${ }^{\mathrm{s}}$, Downy Woodpeckers Eastern Bluebird, Eastern Towhee, European Starling, Fish Crow ${ }^{\mathrm{s}}$, Gray Catbird, Great 
Crested Flycatchers, Hermit Thrush ${ }^{\mathrm{s}}$, House Finch, House Sparrow, House Wren ${ }^{\mathrm{s}}$, Mourning Dove, Northern Cardinal, Northern Flicker, Northern Mockingbird, Northern Parulas , Pine Warbler, Red-bellied Woodpecker, Red-eyed Vireos, Red-headed Woodpeckers ${ }^{\mathrm{s}}$, Rubycrowned Kinglet $^{\mathrm{s}}$, Tufted Titmouse, White-breasted Nuthatch, White-throated Sparrow, Yellow-bellied Sapsucker ${ }^{\mathrm{f}}$, Yellow-rumped Warbler

\section{Durant 2 Average width: $86.2 \mathrm{~m} \quad$ Adjacent land use: OI}

American Crow ${ }^{\mathrm{f}}$, American Goldfinch, American Redstart ${ }^{\mathrm{s}}$, American Robin, Blackpoll Warbler $^{\mathrm{s}}$, Blue Jay, Blue-gray Gnatcatcher ${ }^{\mathrm{s}}$, Brown Thrasher, Brown-headed Cowbird ${ }^{\mathrm{s}}$, Brown-headed Nuthatch, Carolina Chickadee, Carolina Wren, Cedar Waxwings, Chipping Sparrow $^{\mathrm{s}}$, Common Grackles, Common Yellowthroat, Downy Woodpecker ${ }^{\mathrm{s}}$, Eastern Bluebird $^{\mathrm{f}}$, Eastern Towhee, Eastern Wood-Pewee ${ }^{\mathrm{s}}$, European Starling, Fish Crow, Gray Catbird, Great Crested Flycatchers, House Finch's, House Wren ${ }^{\mathrm{s}}$, Mourning Doves , Northern Cardinal, Northern Mockingbird, Orchard Oriole ${ }^{\mathrm{s}}$, Red-bellied Woodpecker ${ }^{\mathrm{s}}$, Red-headed Woodpecker $^{\mathrm{s}}$, Red-shouldered Hawk ${ }^{\mathrm{f}}$, Ruby-crowned Kinglet, Ruby-throated Hummingbird ${ }^{\mathrm{f}}$, Song Sparrow ${ }^{\mathrm{s}}$, Tufted Titmouse, White-eyed Vireo ${ }^{\mathrm{s}}$, White-breasted Nuthatch ${ }^{\mathrm{f}}$, Whitethroated Sparrow, Yellow-rumped Warbler ${ }^{\mathrm{s}}$

\section{Durant 3 Average width: $83.4 \mathrm{~m} \quad$ Adjacent land use: HDR}

American Goldfinch, American Redstart, American Robin, Baltimore Oriole ${ }^{\mathrm{s}}$, Black-andwhite Warblers, Blackpoll Warbler, Blue-gray Gnatcatcher ${ }^{s}$, Blue-headed Vireo ${ }^{f}$, Blue Jay ${ }^{f}$, Brown Thrasher ${ }^{\mathrm{s}}$, Brown-headed Cowbirds, Brown-headed Nuthatch, Carolina Chickadee, Carolina Wren, Cedar Waxwing ${ }^{\mathrm{s}}$, Chipping Sparrows ${ }^{\mathrm{s}}$, Common Grackle ${ }^{\mathrm{s}}$, Common Yellowthroat $^{\mathrm{s}}$, Downy Woodpecker, Eastern Bluebird ${ }^{\mathrm{f}}$, Eastern Towhee, European Starling, Fish Crows ${ }^{\text {s }}$ Gray Catbird, House Finch, House Wren's, Mourning Doves, Northern Cardinal, Northern Flicker ${ }^{\mathrm{s}}$, Northern Mockingbird, Northern Parula ${ }^{\mathrm{s}}$, Red-bellied Woodpecker, Redheaded Woodpeckers ${ }^{\mathrm{s}}$, Red-shouldered Hawk, Ruby-crowned Kinglet, Ruby-throated Hummingbird, Tufted Titmouse White-breasted Nuthatch ${ }^{\mathrm{f}}$, White-eyed Vireo ${ }^{\mathrm{s}}$, Whitethroated Sparrow, Wood Thrush, Yellow Warblers, Yellow-rumped Warbler ${ }^{\mathrm{s}}$

\section{Falls River $1 \quad$ Average width: $108.0 \mathrm{~m} \quad$ Adjacent land use: OI}

American $\mathrm{Crow}^{\mathrm{f}}$, American Goldfinch, American Robin, Black Vulture ${ }^{\mathrm{s}}$, Blue Jay, Blue-gray Gnatcatcher's, Brown Thrasher's, Brown-headed Nuthatch, Carolina Chickadee, Carolina Wren, Cedar Waxwing ${ }^{\mathrm{s}}$, Chipping Sparrow ${ }^{\mathrm{s}}$, Common Grackle ${ }^{\mathrm{s}}$, Common Yellowthroat ${ }^{\mathrm{s}}$, Downy Woodpecker, Eastern Bluebird ${ }^{\mathrm{f}}$, Eastern Towhee, Gray Catbird ${ }^{\mathrm{s}}$, Great Crested Flycatcher $^{\mathrm{s}}$, Hooded Warbler ${ }^{\mathrm{s}}$, House Finch, Mourning Dove, Northern Cardinal, Northern Flicker, Northern Mockingbird, Red-bellied Woodpecker, Red-eyed Vireos ${ }^{\mathrm{s}}$, Red-headed Woodpecker $^{\mathrm{s}}$, Ruby-crowned Kinglet, Ruby-throated Hummingbird ${ }^{\mathrm{f}}$, Summer Tanager ${ }^{\mathrm{s}}$, Tufted Titmouse, Turkey Vulture ${ }^{\mathrm{f}}$, White-breasted Nuthatch, White-eyed Vireo ${ }^{\mathrm{s}}$, Whitethroated Sparrow, Yellow-rumped Warbler ${ }^{\mathrm{s}}$

\section{Falls River 2 Average width: $121.0 \mathrm{~m} \quad$ Adjacent land use: OI}

Blackpoll Warblers, Blue Jays, Blue-gray Gnatcatcher ${ }^{\mathrm{s}}$, Brown-headed Cowbirds, Brownheaded Nuthatchs ${ }^{\mathrm{s}}$, Carolina Chickadee, Carolina Wren, Cedar Waxwing ${ }^{\mathrm{s}}$, Chipping Sparrow ${ }^{\mathrm{s}}$, 
Common Grackles, Common Yellowthroat ${ }^{\mathrm{f}}$, Downy Woodpecker, Eastern Bluebirds, Eastern Towhee, Fish Crows , Gray Catbird ${ }^{\mathrm{s}}$, Great Crested Flycatcher ${ }^{\mathrm{s}}$, Hairy Woodpecker ${ }^{\mathrm{s}}$, House Finch $^{\mathrm{s}}$, Mourning Doves, Northern Cardinal, Northern Flicker ${ }^{\mathrm{f}}$, Northern Mockingbird ${ }^{\mathrm{s}}$, Northern Parulas, Pine Warbler ${ }^{\mathrm{s}}$, Red-bellied Woodpecker, Red-eyed Vireo ${ }^{\mathrm{s}}$, Ruby-crowned Kinglet $^{\mathrm{s}}$, Ruby-throated Hummingbird ${ }^{\mathrm{f}}$, Summer Tanager ${ }^{\mathrm{s}}$, Tufted Titmouse, Unknown Warbler ${ }^{\mathrm{f}}$, White-breasted Nuthatch, White-eyed Vireo ${ }^{\mathrm{s}}$, White-throated Sparrow, Yellowrumped Warbler ${ }^{\mathrm{s}}$

\section{Higgins Average width: $74.4 \mathrm{~m} \quad$ Adjacent land use: LDR}

American Goldfinch $^{\mathrm{f}}$, American Redstart, American Robin, Black-and-white Warbler ${ }^{\mathrm{s}}$, Blackpoll Warblers, Black-throated Blue Warbler ${ }^{\mathrm{s}}$, Blue Jay, Blue-gray Gnatcatcher ${ }^{\mathrm{s}}$, Blueheaded Vireo ${ }^{\mathrm{f}}$, Brown Thrasher, Brown-headed Cowbird ${ }^{\mathrm{s}}$, Carolina Chickadee, Carolina Wren, Cedar Waxwings, Common Grackles, Common Yellowthroat, Downy Woodpecker, Eastern Bluebird ${ }^{\mathrm{f}}$ Eastern Towhee, Gray Catbird, Great Crested Flycatcher ${ }^{\mathrm{s}}$, House Finch, Indigo Buntings, Mallard ${ }^{\mathrm{s}}$, Northern Cardinal, Northern Flicker, Northern Parula ${ }^{\mathrm{s}}$, Northern Waterthrush $^{\text {s, Pine Warbler }}{ }^{\mathrm{s}}$, Red-bellied Woodpecker, Red-eyed Vireos ${ }^{\text {s }}$, Ruby-crowned Kinglet, Ruby-throated Hummingbird, Scarlet Tanager's, Tufted Titmouse, Unknown Warbler ${ }^{\mathrm{f}}$, White-breasted Nuthatch, White-throated Sparrow, Yellow-bellied Sapsucker ${ }^{\mathrm{f}}$, Yellow-rumped Warbler

\section{Hinshaw 1 Average width: $110.4 \mathrm{~m}$ Adjacent land use: LDR}

American Crow, American Goldfinch, American Redstart, American Robin, Black-and-white Warblers, Blackpoll Warblers, Black-throated Blue Warblers, Black-throated Green Warblers, Blue Jay, Blue-gray Gnatcatcher ${ }^{\mathrm{s}}$, Blue-headed Vireos, Brown Creeper ${ }^{\mathrm{s}}$, Brown Thrashers, Brown-headed Cowbird ${ }^{\mathrm{s}}$, Carolina Chickadee, Carolina Wren, Cedar Waxwing ${ }^{\mathrm{s}}$, Common Yellowthroat $^{\mathrm{s}}$, Downy Woodpecker, Eastern Bluebird ${ }^{\mathrm{s}}$, Eastern Towhee, Eastern WoodPewee $^{\mathrm{s}}$, Gray Catbird ${ }^{\mathrm{s}}$, Great Crested Flycatcher ${ }^{\mathrm{s}}$, Hermit Thrush ${ }^{\mathrm{f}}$, House Finch ${ }^{\mathrm{s}}$, House Wren $^{\mathrm{s}}$, Louisiana Waterthrush ${ }^{\mathrm{s}}$, Mourning Dove ${ }^{\mathrm{s}}$, Northern Cardinal, Northern Parula ${ }^{\mathrm{s}}$, Northern Flicker ${ }^{\mathrm{f}}$, Ovenbird ${ }^{\mathrm{s}}$, Red-bellied Woodpecker, Red-eyed Vireo ${ }^{\mathrm{s}}$, Ruby-crowned Kinglet $^{\mathrm{s}}$, Ruby-throated Hummingbird ${ }^{\mathrm{f}}$, Scarlet Tanager ${ }^{\mathrm{s}}$, Swainson's Thrush ${ }^{\mathrm{s}}$, Tufted Titmouse, Unknown Warbler ${ }^{f}$, Veery ${ }^{\mathrm{s}}$, White-breasted Nuthatch, White-throated Sparrow, Wood Thrush ${ }^{\mathrm{s}}$, Yellow-rumped Warbler ${ }^{\mathrm{s}}$

\section{Hinshaw 2 Average width: $148.4 \mathrm{~m} \quad$ Adjacent land use: LDR}

Acadian Flycatcher, American Goldfinch, American Redstart, American Robin, Black-andwhite Warblers, Black-throated Blue Warbler ${ }^{\mathrm{s}}$, Blue Jay, Blue-gray Gnatcatcher ${ }^{\mathrm{s}}$, Brownheaded Cowbird ${ }^{\mathrm{s}}$, Brown Thrasher ${ }^{\mathrm{f}}$, Carolina Chickadee, Carolina Wren, Cedar Waxwing ${ }^{\mathrm{s}}$, Common Grackles, Common Yellowthroat ${ }^{\mathrm{s}}$, Downy Woodpecker, Eastern Phoebe ${ }^{\mathrm{s}}$, Eastern Towhee, Gray Catbird ${ }^{\mathrm{s}}$, Great Crested Flycatcher ${ }^{\mathrm{s}}$, Hairy Woodpecker ${ }^{\mathrm{s}}$, Hermit Thrush ${ }^{\mathrm{s}}$, Hooded Warblers, House Finch ${ }^{\mathrm{s}}$, Mourning Doves, Northern Cardinal, Northern Flicker, Northern Parulas, Red-bellied Woodpecker, Red-eyed Vireos, Red-shouldered Hawk ${ }^{\mathrm{s}}$, Rubycrowned Kinglet ${ }^{\mathrm{s}}$, Scarlet Tanager ${ }^{\mathrm{s}}$, Tufted Titmouse, White-breasted Nuthatch, Whitethroated Sparrow ${ }^{\mathrm{s}}$, Wood Thrush, Yellow-rumped Warbler ${ }^{\mathrm{s}}$ 
Hinshaw 3 Average width: $145.3 \mathrm{~m} \quad$ Adjacent land use: LDR American Goldfinch, American Redstart ${ }^{\mathrm{s}}$, American Robin, Black-and-white Warblers, Blackpoll Warbler ${ }^{\mathrm{s}}$, Black-throated Blue Warblers, Blue Jay, Blue-gray Gnatcatcher ${ }^{\mathrm{s}}$, Brown Thrasher $^{\mathrm{s}}$, Brown-headed Cowbird ${ }^{\mathrm{s}}$, Brown-headed Nuthatch ${ }^{\mathrm{s}}$, Carolina Chickadee, Carolina Wren, Common Grackle, Downy Woodpecker, Eastern Towhee, Gray Catbird ${ }^{\mathrm{s}}$, Great Crested Flycatcher ${ }^{\mathrm{s}}$, Hairy Woodpecker ${ }^{\mathrm{s}}$, Hooded Warbler ${ }^{\mathrm{s}}$, House Wren ${ }^{\mathrm{s}}$, Mourning Dove ${ }^{\mathrm{f}}$, Northern Cardinal, Northern Flicker, Northern Mockingbird ${ }^{\mathrm{f}}$, Ovenbird ${ }^{\mathrm{s}}$, Red-bellied Woodpecker, Red-eyed Vireo ${ }^{\mathrm{s}}$, Ruby-crowned Kinglet, Ruby-throated Hummingbird ${ }^{\mathrm{s}}$, Tufted Titmouse, Unknown Warbler ${ }^{\mathrm{f}}$, White-breasted Nuthatch, White-throated Sparrow, Wood Thrush, Yellow-rumped Warbler ${ }^{\mathrm{s}}$

Ironwood Average width: $252.8 \mathrm{~m} \quad$ Adjacent land use: LDR

Acadian Flycatchers, American Goldfinch, American Robin, Blackpoll Warbler ${ }^{\mathrm{s}}$, Blue Jay, Blue-gray Gnatcatcher ${ }^{\mathrm{s}}$, Brown Thrasher, Brown-headed Cowbird ${ }^{\mathrm{s}}$, Brown-headed Nuthatch, Carolina Chickadee, Carolina Wren, Common Grackles , Common Yellowthroat ${ }^{\mathrm{s}}$, Downy Woodpecker, Eastern Towhee, Gray Catbird, Great Crested Flycatcher ${ }^{\mathrm{s}}$, Hairy Woodpecker ${ }^{\mathrm{f}}$, Hooded Warbler ${ }^{\mathrm{s}}$, Magnolia Warbler ${ }^{\mathrm{f}}$, Mourning Dove ${ }^{\mathrm{s}}$, Northern Cardinal, Ovenbird ${ }^{\mathrm{s}}$, Pine Warbler, Red-bellied Woodpecker, Red-eyed Vireo ${ }^{s}$, Red-headed Woodpecker, Redshouldered Hawk ${ }^{\mathrm{s}}$ Ruby-crowned Kinglet, Ruby-throated Hummingbird, Summer Tanagers, Tufted Titmouse, Veery ${ }^{\mathrm{s}}$, White-breasted Nuthatch, White-throated Sparrow, Wood Thrush ${ }^{\mathrm{s}}$, Yellow-rumped Warbler ${ }^{\mathrm{s}}$

Lynn Average width: $170.3 \mathrm{~m}$ Adjacent land use: HDR American Goldfinch, American Robin, Belted Kingfisher ${ }^{\mathrm{s}}$, Black-and-white Warblers, Blackpoll Warbler, Blue Jay, Blue-gray Gnatcatcher ${ }^{\mathrm{s}}$, Blue-winged Warbler ${ }^{\mathrm{f}}$, Brown Thrasher, Brown-headed Cowbirds, Brown-headed Nuthatch's, Carolina Chickadee, Carolina Wren, Cedar Waxwings ${ }^{\mathrm{s}}$, Common Grackle ${ }^{\mathrm{s}}$, Common Yellowthroat ${ }^{\mathrm{f}}$, Downy Woodpecker, Eastern Kingbird ${ }^{\mathrm{s}}$, Eastern Phoebe, Eastern Towhee, Gray Catbird, Great Crested Flycatchers, Great Blue Heron's, Northern Cardinal, Northern Flicker, Northern Parula ${ }^{\mathrm{s}}$, Redbellied Woodpecker, Red-eyed Vireos, Ruby-crowned Kinglet ${ }^{\mathrm{s}}$, Ruby-throated Hummingbirds ${ }^{\mathrm{s}}$, Tufted Titmouse, Unknown Warbler ${ }^{\mathrm{f}}$, White-breasted Nuthatch, White-eyed Vireos, White-throated Sparrow ${ }^{\mathrm{s}}$, Wood Thrush ${ }^{\mathrm{s}}$, Worm-eating Warblers, Yellow-rumped Warbler $^{\mathrm{s}}$

North Hills 1 Average width: $124.6 \mathrm{~m} \quad$ Adjacent land use: OI American $\mathrm{Crow}^{\mathrm{f}}$, American Goldfinch, American Robin, Belted Kingfisher ${ }^{\mathrm{s}}$, Black-andwhite Warblers, Blue Jay, Blue-gray Gnatcatcher ${ }^{\mathrm{s}}$, Brown Thrasher, Brown-headed Cowbird ${ }^{\mathrm{s}}$, Brown-headed Nuthatch ${ }^{\mathrm{s}}$, Canada Gooses, Carolina Chickadee, Carolina Wren, Cedar Waxwings, Common Grackles , Common Yellowthroat, Downy Woodpecker, Eastern Kingbird ${ }^{\mathrm{s}}$, Eastern Phoebe ${ }^{\mathrm{f}}$, Eastern Towhee, European Starling ${ }^{\mathrm{s}}$, Gray Catbird ${ }^{\mathrm{f}}$, Great Blue Heron $^{\mathrm{f}}$, Great Crested Flycatcher ${ }^{\mathrm{s}}$, House Finch, Mourning Doves, Northern Cardinal, Northern Flicker, Northern Mockingbird, Red-bellied Woodpecker, Red-eyed Vireos, Rosebreasted Grosbeak ${ }^{\mathrm{s}}$, Ruby-crowned Kinglet, Ruby-throated Hummingbird, Tufted Titmouse, White-eyed Vireo ${ }^{\mathrm{f}}$, White-throated Sparrow, Yellow-rumped Warbler 
North Hills 2 Average width: $271.3 \mathrm{~m} \quad$ Adjacent land use: HDR American Crow ${ }^{\mathrm{f}}$, Acadian Flycatcher ${ }^{\mathrm{s}}$, American Goldfinch ${ }^{\mathrm{s}}$, American Robin, Belted Kingfishers, Blue-gray Gnatcatcher ${ }^{\mathrm{s}}$, Brown-headed Cowbird ${ }^{\mathrm{s}}$, Brown-headed Nuthatch's Brown Thrasher ${ }^{\mathrm{f}}$, Canada Goose ${ }^{\mathrm{s}}$, Carolina Chickadee, Carolina Wren, Cedar Waxwing ${ }^{\mathrm{s}}$, Common Grackles, Downy Woodpecker, Eastern Towhee, Gray Catbird, Great Crested Flycatcher $^{\mathrm{s}}$, House Finchs, Mallard ${ }^{\mathrm{s}}$, Mourning Doves, Northern Cardinal, Northern Flickers, Red-bellied Woodpecker, Red-eyed Vireos ${ }^{\mathrm{s}}$, Ruby-crowned Kinglet ${ }^{\mathrm{s}}$, Ruby-throated Hummingbird $^{\mathrm{s}}$, Tufted Titmouse, Unknown Warbler ${ }^{\mathrm{f}}$, White-throated Sparrow ${ }^{\mathrm{s}}$, Yellowrumped Warbler ${ }^{\mathrm{s}}$

Oxxford Hunt Average width: $66.9 \mathrm{~m} \quad$ Adjacent land use: LDR American Crow ${ }^{\mathrm{f}}$, American Goldfinch, American Redstart ${ }^{\mathrm{s}}$, American Robin, Black-throated Blue Warbler ${ }^{\mathrm{s}}$, Blue Jay, Blue-gray Gnatcatcher ${ }^{\mathrm{s}}$, Brown Thrasher ${ }^{\mathrm{s}}$, Brown-headed Cowbird , Carolina Chickadee, Carolina Wren, Cedar Waxwings, Common Grackles, Downy Woodpecker, Eastern Bluebird ${ }^{\mathrm{f}}$, Eastern Phoebe ${ }^{\mathrm{s}}$, Eastern Towhee , Gray Catbird, Great Crested Flycatcher ${ }^{\mathrm{s}}$, House Finch ${ }^{\mathrm{s}}$, Mourning Dove ${ }^{\mathrm{s}}$, Northern Cardinal, Northern Flicker ${ }^{\mathrm{s}}$, Northern Parulas, Ovenbird ${ }^{\mathrm{s}}$, Red-bellied Woodpecker, Red-eyed Vireo ${ }^{\mathrm{s}}$, Ruby-crowned Kinglet $^{\mathrm{s}}$, Ruby-throated Hummingbird ${ }^{\mathrm{s}}$, Tufted Titmouse, White-breasted Nuthatch, Whitethroated Sparrow, Yellow-rumped Warbler ${ }^{\mathrm{s}}$

Oak Park 1 Average width: $65.9 \mathrm{~m} \quad$ Adjacent land use: OI American Crow ${ }^{\mathrm{f}}$, American Goldfinch ${ }^{\mathrm{s}}$, American Redstart ${ }^{\mathrm{s}}$, American Robin, Blackthroated Blue Warbler ${ }^{\mathrm{s}}$, Blue Jay, Blue-gray Gnatcatcher ${ }^{\mathrm{s}}$, Brown-headed Cowbird ${ }^{\mathrm{s}}$, Brownheaded Nuthatch ${ }^{\mathrm{s}}$, Carolina Chickadee, Carolina Wren, Cedar Waxwing ${ }^{\mathrm{s}}$, Chipping Sparrow ${ }^{\mathrm{s}}$, Common Yellowthroat ${ }^{\mathrm{s}}$, Eastern Towhee, Gray Catbird ${ }^{\mathrm{s}}$, Great Crested Flycatcher ${ }^{\mathrm{s}}$, Hooded Warbler $^{\mathrm{s}}$, House Finch ${ }^{\mathrm{s}}$, Mourning Doves , Northern Cardinal, Northern Parula ${ }^{\mathrm{s}}$, Red-bellied Woodpecker, Red-eyed Vireos, Ruby-crowned Kinglet, Ruby-throated Hummingbird ${ }^{\mathrm{s}}$, Swainson's Thrush's, Tufted Titmouse, White-breasted Nuthatch, White-throated Sparrow, Yellow-bellied Sapsucker ${ }^{\mathrm{f}}$, Yellow-rumped Warbler

Oak Park 2 Average width: $263.3 \mathrm{~m} \quad$ Adjacent land use: OI American Goldfinch, American Robin, Blue Jay, Blue-gray Gnatcatchers ${ }^{\mathrm{s}}$, Brown Thrasher, Brown-headed Cowbird ${ }^{\mathrm{s}}$, Carolina Chickadee, Carolina Wren, Cedar Waxwing ${ }^{\mathrm{s}}$, Chipping Sparrow $^{\mathrm{s}}$, Common Yellowthroat, Downy Woodpecker, Eastern Bluebird ${ }^{\mathrm{f}}$, Eastern Kingbird $^{\mathrm{s}}$, Eastern Towhee ${ }^{\mathrm{s}}$, Gray Catbird, Great Crested Flycatcher ${ }^{\mathrm{s}}$, House Finch ${ }^{\mathrm{s}}$, House Sparrow $^{\mathrm{s}}$, House Wren ${ }^{\mathrm{s}}$, Indigo Bunting ${ }^{\mathrm{s}}$, Mourning Doves, Northern Cardinal, Northern Flicker ${ }^{\mathrm{f}}$, Northern Mockingbird ${ }^{\mathrm{f}}$, Northern Parula ${ }^{\mathrm{s}}$, Red-bellied Woodpecker ${ }^{\mathrm{f}}$, Ruby-crowned Kinglet $^{\mathrm{s}}$, Ruby-throated Hummingbird ${ }^{\mathrm{s}}$, Tufted Titmouse, White-eyed Vireos ${ }^{\mathrm{s}}$, White-throated Sparrow, Yellow-rumped Warbler

\section{Parkway Average width: $76.1 \mathrm{~m} \quad$ Adjacent land use: LDR}

American Crow, American Goldfinch, American Robin, Blue Jay, Blue-gray Gnatcatchers, Brown-headed Nuthatch ${ }^{\mathrm{f}}$, Brown Thrasher ${ }^{\mathrm{s}}$, Carolina Chickadee, Carolina Wren, Common Grackle $^{\mathrm{f}}$, Dark-eyed Juncos , Eastern Bluebird ${ }^{\mathrm{f}}$, Eastern Towhee, Gray Catbird ${ }^{\mathrm{s}}$, House Finch ${ }^{\mathrm{s}}$, 
Mourning Doves , Northern Cardinal, Northern Flicker, Pine Warbler ${ }^{\mathrm{s}}$, Red-bellied Woodpecker, Red-headed Woodpecker ${ }^{\mathrm{s}}$, Ruby-crowned Kinglet ${ }^{\mathrm{f}}$, Tufted Titmouse, Unknown Warbler ${ }^{\mathrm{f}}$, White-breasted Nuthatch ${ }^{\mathrm{f}}$, White-throated Sparrow, Yellow-rumped Warbler ${ }^{\mathrm{s}}$

Pirate's Cove 1 Average width: $152.9 \mathrm{~m} \quad$ Adjacent land use: HDR American Goldfinch, American Redstart ${ }^{\mathrm{s}}$, American Robin, Black-and-white Warbler ${ }^{\mathrm{s}}$, Black-throated Blue Warblers ${ }^{\mathrm{s}}$, Blue-gray Gnatcatcher ${ }^{\mathrm{s}}$, Blue Jay ${ }^{\mathrm{f}}$, Brown Thrasher ${ }^{\mathrm{s}}$, Brownheaded Cowbird ${ }^{\mathrm{s}}$, Brown-headed Nuthatch, Carolina Chickadee, Carolina Wren, Cedar Waxwings, Common Yellowthroats ${ }^{\mathrm{s}}$, Downy Woodpecker, Eastern Towhee ${ }^{\mathrm{s}}$, Gray Catbird ${ }^{\mathrm{s}}$, Great Crested Flycatcher ${ }^{\mathrm{s}}$, House Finch, Mourning Dove, Northern Cardinal, Northern Flicker, Northern Parulas, Ovenbirds', Red-bellied Woodpecker, Red-eyed Vireos, Rubycrowned Kinglet, Ruby-throated Hummingbird ${ }^{\text {s }}$ Tufted Titmouse, White-breasted Nuthatch, White-throated Sparrow ${ }^{\mathrm{s}}$, Wood Thrush, Yellow-rumped Warbler ${ }^{\mathrm{s}}$

Pirate's Cove 2 Average width: $109.0 \mathrm{~m} \quad$ Adjacent land use: LDR American Crow ${ }^{\mathrm{s}}$, American Goldfinch ${ }^{\mathrm{s}}$, American Redstart ${ }^{\mathrm{s}}$, American Robin, Belted Kingfisher ${ }^{\mathrm{s}}$, Black-and-white Warbler ${ }^{\mathrm{s}}$, Blackpoll Warbler ${ }^{\mathrm{s}}$, Black-throated Blue Warbler ${ }^{\mathrm{s}}$, Blue Jay, Blue-gray Gnatcatcher ${ }^{\mathrm{s}}$, Blue-headed Vireo ${ }^{\mathrm{s}}$, Brown Thrasher ${ }^{\mathrm{s}}$, Brown-headed Cowbird $^{\mathrm{s}}$, Carolina Chickadee, Carolina Wren, Cedar Waxwing ${ }^{\mathrm{s}}$, Common Yellowthroat ${ }^{\mathrm{s}}$, Downy Woodpecker, Eastern Towhee, Gray Catbird ${ }^{\mathrm{s}}$, Great Crested Flycatcher ${ }^{\mathrm{s}}$, Hooded Warbler ${ }^{\mathrm{f}}$, House Finch ${ }^{\mathrm{s}}$, Louisiana Waterthrush ${ }^{\mathrm{s}}$, Northern Cardinal, Northern Flicker, Northern Parulas, Ovenbirds, Pine Warblers, Red-bellied Woodpecker, Red-eyed Vireos ${ }^{\mathrm{s}}$, Redshouldered Hawk ${ }^{\mathrm{s}}$, Ruby-crowned Kinglet ${ }^{\mathrm{s}}$, Scarlet Tanager ${ }^{\mathrm{s}}$, Tufted Titmouse, Whitebreasted Nuthatch ${ }^{\mathrm{s}}$, White-throated Sparrow, Wood Thrush's, Yellow-rumped Warbler ${ }^{\mathrm{s}}$

Shelley Average width: $120.8 \mathrm{~m} \quad$ Adjacent land use: LDR American Crow, American Goldfinch, American Robins', Blackpoll Warbler ${ }^{\mathrm{s}}$, Blue Jay , Blue-gray Gnatcatchers, Brown Thrasher ${ }^{\mathrm{s}}$, Brown-headed Cowbird ${ }^{\mathrm{s}}$, Brown-headed Nuthatch $^{\mathrm{s}}$, Carolina Chickadee, Carolina Wren, Cedar Waxwings, Common Grackles, Downy Woodpecker, Eastern Screech-Owl ${ }^{\mathrm{s}}$, Eastern Towhee, Gray Catbird, Hermit Thrush ${ }^{\mathrm{s}}$, Mourning Dove, Northern Cardinal, Northern Parulas, Ovenbird ${ }^{\mathrm{s}}$, Pine Warbler ${ }^{\mathrm{s}}$, Red-bellied Woodpecker, Ruby-crowned Kinglet ${ }^{\mathrm{s}}$, Ruby-throated Hummingbird ${ }^{\mathrm{s}}$, Tufted Titmouse, White-breasted Nuthatch, White-throated Sparrow, Yellow-rumped Warbler ${ }^{\mathrm{s}}$

Sawmill $1 \quad$ Average width: $95.7 \mathrm{~m} \quad$ Adjacent land use: LDR Acadian Flycatcher ${ }^{\mathrm{s}}$, American Crow ${ }^{\mathrm{s}}$, American Goldfinch, American Redstart ${ }^{\mathrm{s}}$, American Robin $^{\text {s }}$, Belted Kingfisher ${ }^{\mathrm{s}}$, Black-and-white Warbler ${ }^{\mathrm{s}}$, Blackpoll Warbler ${ }^{\mathrm{s}}$, Black-throated Blue Warbler ${ }^{\mathrm{s}}$, Blue Jays, Blue-gray Gnatcatcher ${ }^{\mathrm{s}}$, Brown Thrasher, Brown-headed Cowbirds, Carolina Chickadee, Carolina Wren, Cedar Waxwings, Common Grackles, Downy Woodpecker, Eastern Towhee, Gray Catbird ${ }^{\mathrm{s}}$, Great Crested Flycatcher ${ }^{\mathrm{s}}$, Green Heron ${ }^{\mathrm{f}}$, Hermit Thrush ${ }^{\mathrm{f}}$, Hooded Warbler ${ }^{\mathrm{s}}$, Mourning Dove ${ }^{\mathrm{s}}$, Northern Cardinal, Northern Parula ${ }^{\mathrm{s}}$, Red-bellied Woodpecker, Red-eyed Vireo ${ }^{\mathrm{s}}$, Red-shouldered Hawk ${ }^{\mathrm{s}}$, Ruby-crowned Kinglet ${ }^{\mathrm{s}}$, 
Ruby-throated Hummingbird ${ }^{\text {s }}$ Tufted Titmouse, White-breasted Nuthatch, White-throated Sparrow $^{\mathrm{s}}$, Yellow-rumped Warbler ${ }^{\mathrm{s}}$

Sawmill 2 Average width: $64.3 \mathrm{~m} \quad$ Adjacent land use: HDR Acadian Flycatchers ${ }^{\mathrm{s}}$, American Crows ${ }^{\mathrm{s}}$, American Goldfinch, American Robin, Belted Kingfisher $^{\mathrm{s}}$, Blackpoll Warblers, Black-throated Blue Warbler ${ }^{\mathrm{s}}$, Blue Jay, Blue-gray Gnatcatcher ${ }^{s}$, Brown Thrasher, Brown-headed Nuthatch ${ }^{\mathrm{s}}$, Carolina Chickadee, Carolina Wren, Cedar Waxwing ${ }^{\mathrm{s}}$, Common Grackles , Common Yellowthroat ${ }^{\mathrm{s}}$, Downy Woodpecker, Eastern Phoebe ${ }^{\mathrm{s}}$, Eastern Towhee, Gray Catbird, Hairy Woodpecker ${ }^{\mathrm{s}}$, House Finch ${ }^{\mathrm{s}}$, Mallards, Mourning Doves, Northern Cardinal, Northern Parulas, Red-bellied Woodpecker, Red-eyed Vireo ${ }^{\mathrm{s}}$, Ruby-crowned Kinglet ${ }^{\mathrm{s}}$, Ruby-throated Hummingbird ${ }^{\mathrm{s}}$, Swainson's Thrush $^{\mathrm{s}}$, Tufted Titmouse, White-breasted Nuthatch, White-throated Sparrow ${ }^{\mathrm{s}}$, Yellowrumped Warbler ${ }^{\mathrm{s}}$

\section{Swift Creek Average width: $366.2 \mathrm{~m} \quad$ Adjacent land use: OI} Acadian Flycatcher ${ }^{\text {s }}$, American Crow, American Goldfinch, American Robin, Belted Kingfisher $^{\text {s }}$, Blackpoll Warblers, Black-throated Blue Warbler, Blue Jays, Blue-gray Gnatcatcher ${ }^{\mathrm{s}}$, Blue-headed Vireo, Brown Thrasher, Brown-headed Cowbird ${ }^{\mathrm{s}}$, Carolina Chickadee, Carolina Wren, Cedar Waxwing ${ }^{\mathrm{s}}$, Common Grackles ${ }^{\mathrm{s}}$, Common Yellowthroat ${ }^{\mathrm{s}}$, Downy Woodpecker, Eastern Towhee, Empidonax Flycatcher ${ }^{\mathrm{f}}$, Gray Catbird, Great Blue Heron $^{\mathrm{f}}$, Great Crested Flycatcher ${ }^{\mathrm{s}}$, Hairy Woodpecker ${ }^{\mathrm{f}}$, Louisiana Waterthrush ${ }^{\mathrm{s}}$, Mallard ${ }^{\mathrm{s}}$, Mourning Dove ${ }^{\mathrm{s}}$, Northern Cardinal, Northern Flicker ${ }^{\mathrm{f}}$, Northern Mockingbird, Northern Parula $^{\mathrm{s}}$, Orchard Oriole ${ }^{\mathrm{s}}$, Ovenbirds, Red-bellied Woodpecker, Red-eyed Vireo, Rubycrowned Kinglet, Ruby-throated Hummingbird, Scarlet Tanager ${ }^{\mathrm{s}}$, Summer Tanager ${ }^{\mathrm{s}}$, Tufted Titmouse, Unknown Warbler ${ }^{\mathrm{f}}$, White-breasted Nuthatch, White-eyed Vireo ${ }^{\mathrm{s}}$, White-throated Sparrow, Wood Thrush ${ }^{\text {s }}$ Yellow Warblers, Yellow-rumped Warbler

\section{Trafalgar Average width: $55.2 \mathrm{~m} \quad$ Adjacent land use: LDR} American Crow ${ }^{\mathrm{s}}$, American Goldfinch, American Robin, Barred Owl's, Blue Jay, Brown Thrasher, Brown-headed Cowbird ${ }^{\mathrm{s}}$, Brown-headed Nuthatch ${ }^{\mathrm{s}}$, Carolina Chickadee, Carolina Wren, Chipping Sparrow ${ }^{\mathrm{s}}$, Common Grackles Eastern Bluebird $^{\mathrm{s}}$, Eastern Towhee ${ }^{\mathrm{s}}$, Hooded Warbler ${ }^{\mathrm{s}}$, House Finch' ${ }^{\mathrm{s}}$, Mourning Doves ${ }^{\mathrm{s}}$, Northern Cardinal, Northern Flicker, Northern Mockingbird $^{\mathrm{s}}$, Prairie Warblers ${ }^{\mathrm{s}}$, Red-bellied Woodpecker, Ruby-crowned Kinglet, Tufted Titmouse, White-breasted Nuthatch, White-throated Sparrow ${ }^{\mathrm{s}}$, Yellow-rumped Warbler

Tarbert 1 Average width: $103.7 \mathrm{~m} \quad$ Adjacent land use: LDR Acadian Flycatcher ${ }^{\mathrm{s}}$, American Crow, American Goldfinch, American Robin, Baltimore Orioles, Black-and-white Warblers, Blackpoll Warbler ${ }^{\text {s }}$, Black-throated Blue Warblers, Blackthroated Green Warbler ${ }^{\mathrm{f}}$, Blue Jay, Blue-gray Gnatcatcher ${ }^{\mathrm{s}}$, Brown-headed Cowbird ${ }^{\mathrm{s}}$, Brownheaded Nuthatch, Carolina Chickadee, Carolina Wren, Common Grackles, Common Yellowthroat $^{\mathrm{s}}$, Downy Woodpecker, Eastern Bluebird ${ }^{\mathrm{f}}$, Eastern Towhee, Eastern WoodPewee $^{\mathrm{s}}$, Empidonax Flycatcher ${ }^{\mathrm{s}}$, Fish Crow ${ }^{\mathrm{s}}$, Gray Catbird ${ }^{\mathrm{s}}$, Great Crested Flycatcher ${ }^{\mathrm{f}}$, House Finch $^{\mathrm{s}}$, Mourning Dove ${ }^{\mathrm{s}}$, Northern Cardinal, Northern Flicker, Northern Parula ${ }^{\mathrm{s}}$, Pine 
Warbler, Red-bellied Woodpecker, Red-shouldered Hawks , Ruby-crowned Kinglet, Tufted Titmouse, White-breasted Nuthatch, White-throated Sparrow ${ }^{\mathrm{s}}$, Wood Thrush's, Yellowbellied Sapsucker ${ }^{\mathrm{f}}$, Yellow-rumped Warbler

\section{Tarbert 2 Average width: $94.3 \mathrm{~m} \quad$ Adjacent land use: HDR}

American Crow, American Goldfinch ${ }^{\mathrm{s}}$, American Robin, Blue Jay ${ }^{\mathrm{s}}$, Blue-gray Gnatcatcher ${ }^{\mathrm{s}}$, Brown-headed Nuthatch ${ }^{\mathrm{f}}$, Brown Thrasher ${ }^{\mathrm{s}}$, Brown-headed Cowbird ${ }^{\mathrm{s}}$, Carolina Chickadee, Carolina Wren, Downy Woodpecker, Eastern Towhee ${ }^{\mathrm{s}}$, Golden-crowned Kinglet ${ }^{\mathrm{f}}$, Gray Catbird, Great Crested Flycatchers, Hermit Thrush's, House Finch's ${ }^{\mathrm{s}}$, House Wren ${ }^{\mathrm{s}}$, Northern Cardinal, Northern Flicker, Northern Parulas, Pine Warbler's, Red-bellied Woodpecker, Redshouldered Hawk ${ }^{\mathrm{s}}$, Ruby-crowned Kinglet, Ruby-throated Hummingbird ${ }^{\mathrm{s}}$, Tufted Titmouse, Unknown Warbler ${ }^{\mathrm{f}}$, White-breasted Nuthatch, White-throated Sparrow, Wood Thrush ${ }^{\mathrm{s}}$, Yellow-rumped Warbler ${ }^{\mathrm{s}}$

Umstead 1 Reference Segment Acadian Flycatcher ${ }^{\mathrm{s}}$, American Goldfinch, American Redstart ${ }^{\mathrm{f}}$, Belted Kingfisher ${ }^{\mathrm{s}}$, Blackand-white Warbler, Black-throated Blue Warbler, Black-throated Green Warbler ${ }^{\mathrm{f}}$, Blue Jay ${ }^{\mathrm{s}}$, Blue-gray Gnatcatchers, Brown-headed Cowbird's, Carolina Chickadee, Carolina Wren, Downy Woodpecker ${ }^{\mathrm{f}}$, Eastern Bluebird ${ }^{\mathrm{f}}$, Eastern Wood-Pewee ${ }^{\mathrm{f}}$, Golden-crowned Kinglet ${ }^{\mathrm{f}}$, Great Blue Herons ${ }^{\mathrm{s}}$, Great Crested Flycatcher ${ }^{\mathrm{s}}$, Hairy Woodpecker ${ }^{\mathrm{f}}$, Magnolia Warbler ${ }^{\mathrm{f}}$, Mallard $^{\mathrm{s}}$, Mourning Dove ${ }^{\mathrm{s}}$, Northern Cardinal, Northern Parulas, Ovenbird ${ }^{\mathrm{s}}$, Pine Warbler, Red-bellied Woodpecker, Red-eyed Vireo, Red-headed Woodpeckers, Ruby-crowned Kinglet $^{\mathrm{f}}$, Ruby-throated Hummingbird ${ }^{\mathrm{s}}$, Summer Tanager ${ }^{\mathrm{s}}$, Tufted Titmouse, White-breasted Nuthatch, White-throated Sparrow ${ }^{\mathrm{f}}$, Wood Thrush ${ }^{\mathrm{s}}$, Yellow-bellied Sapsucker ${ }^{\mathrm{f}}$, Yellowrumped Warbler, Yellow-throated Warbler ${ }^{\mathrm{s}}$

Umstead 2 Reference Segment

Acadian Flycatcher ${ }^{\mathrm{s}}$, American Goldfinch ${ }^{\mathrm{s}}$, American Redstart ${ }^{\mathrm{f}}$, Black-and-white Warbler, Black-throated Blue Warbler ${ }^{f}$, Black-throated Green Warblers, Blue-gray Gnatcatcher ${ }^{\mathrm{s}}$, Blueheaded Vireos, Brown-headed Cowbird ${ }^{\mathrm{s}}$, Carolina Chickadee, Carolina Wren, Common

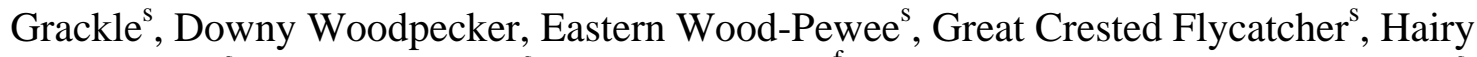
Woodpecker ${ }^{\mathrm{s}}$, Mourning Doves ${ }^{\mathrm{s}}$, Northern Flicker ${ }^{\mathrm{f}}$, Northern Cardinal, Northern Parula ${ }^{\mathrm{s}}$, Pileated Woodpecker ${ }^{\mathrm{f}}$, Pine Warbler ${ }^{\mathrm{s}}$, Red-bellied Woodpecker, Red-eyed Vireo ${ }^{\mathrm{s}}$, Rubycrowned Kinglet ${ }^{\mathrm{s}}$, Ruby-throated Hummingbird ${ }^{\mathrm{s}}$, Summer Tanager ${ }^{\mathrm{s}}$, Tufted Titmouse, Unknown Warbler ${ }^{\mathrm{f}}$, White-breasted Nuthatch ${ }^{\mathrm{f}}$, White-throated Sparrow ${ }^{\mathrm{s}}$, Worm-eating Warbler, Yellow-rumped Warbler ${ }^{\mathrm{s}}$, Yellow-throated Warbler ${ }^{\mathrm{s}}$

Umstead 3 Reference Segment

Acadian Flycatchers ${ }^{\mathrm{s}}$, American Goldfinch's, American Redstart, Belted Kingfisher's Blackand-white Warbler ${ }^{\mathrm{s}}$, Blue-gray Gnatcatcher ${ }^{\mathrm{s}}$, Brown-headed Cowbird ${ }^{\mathrm{s}}$, Carolina Chickadee, Carolina Wren, Common Grackles, Common Yellowthroat ${ }^{\mathrm{s}}$, Downy Woodpecker ${ }^{\mathrm{s}}$, Eastern Wood-Pewees , Great Blue Heron's , Great Crested Flycatchers, Hairy Woodpecker, Hooded Warbler $^{\mathrm{s}}$, Louisiana Waterthrush's, Mallard's Mourning Doves, Northern Cardinal, Northern Parula $^{\mathrm{s}}$, Ovenbird ${ }^{\mathrm{s}}$, Pine Warblers , Red-bellied Woodpecker, Red-eyed Vireo ${ }^{\mathrm{s}}$, Ruby-crowned 
Kinglet, Ruby-throated Hummingbird ${ }^{\mathrm{s}}$, Tufted Titmouse, Unknown Warbler ${ }^{\mathrm{f}}$, White-throated Sparrow ${ }^{\mathrm{s}}$, Yellow-rumped Warbler ${ }^{\mathrm{s}}$, Yellow-throated Warbler ${ }^{\mathrm{s}}$

\section{Weston 1 Average width: $128.9 \mathrm{~m} \quad$ Adjacent land use: OI}

American Crows, American Goldfinch, American Redstarts ${ }^{\mathrm{s}}$, American Robin's, Black-andwhite Warblers, Blue Grosbeaks, Blue Jay, Blue-gray Gnatcatcher ${ }^{\mathrm{s}}$, Brown Thrasher, Brownheaded Cowbirds, Brown-headed Nuthatch's, Carolina Chickadee, Carolina Wren, Common Grackle $^{\mathrm{f}}$, Common Yellowthroat ${ }^{\mathrm{s}}$, Downy Woodpecker ${ }^{\mathrm{f}}$, Eastern Towhee ${ }^{\mathrm{s}}$, European

Starling ${ }^{\mathrm{f}}$, Great Crested Flycatcher ${ }^{\mathrm{s}}$, House Finch ${ }^{\mathrm{s}}$, Northern Cardinal, Northern Flicker, Northern Parulas, Ovenbird's Red-bellied Woodpecker, Red-eyed Vireos, Red-headed Woodpecker ${ }^{\mathrm{f}}$, Ruby-crowned Kinglet ${ }^{\mathrm{s}}$, Ruby-throated Hummingbird ${ }^{\mathrm{s}}$, Scarlet Tanager ${ }^{\mathrm{s}}$, Tufted Titmouse ，White-breasted Nuthatch, White-throated Sparrow ${ }^{\mathrm{s}}$, Yellow-rumped Warbler $^{\mathrm{s}}$

\section{Weston 2 Average width: $234 \mathrm{~m} \quad$ Adjacent land use: OI} American Goldfinch, American Redstart ${ }^{\mathrm{s}}$, American Robin, Black-and-white Warbler ${ }^{\mathrm{s}}$, Black-throated Blue Warblers, Black-throated Green Warbler ${ }^{\mathrm{s}}$, Blue-gray Gnatcatcher ${ }^{\mathrm{s}}$, Blue Jay $^{\mathrm{f}}$, Brown-headed Cowbird ${ }^{\mathrm{s}}$, Carolina Chickadee, Carolina Wren, Chipping Sparrow ${ }^{\mathrm{s}}$, Common Yellowthroat ${ }^{\mathrm{s}}$, Downy Woodpecker ${ }^{\mathrm{s}}$, Eastern Towhee, Eastern Wood-Pewee , Gray Catbird $^{\mathrm{s}}$, Great Crested Flycatcher ${ }^{\mathrm{s}}$, House Finch ${ }^{\mathrm{s}}$, Mourning Doves, Northern Cardinal, Northern Mockingbird ${ }^{\mathrm{f}}$, Northern Parula ${ }^{\mathrm{s}}$, Ovenbird ${ }^{\mathrm{s}}$, Red-bellied Woodpecker, Red-eyed Vireo $^{\mathrm{s}}$, Red-shouldered Hawk ${ }^{\mathrm{f}}$, Ruby-throated Hummingbird ${ }^{\mathrm{s}}$, Summer Tanager ${ }^{\mathrm{s}}$, Tufted Titmouse, White-breasted Nuthatch, White-throated Sparrows, Wood Thrush ${ }^{\mathrm{s}}$, Yellowrumped Warbler

\section{Walnut 1 Average width: $112.8 \mathrm{~m}$ Adjacent land use: HDR}

American Crow ${ }^{\mathrm{s}}$, American Goldfinch, American Robin, Belted Kingfisher, Blue Jay, Bluegray Gnatcatcher ${ }^{\mathrm{s}}$, Brown-headed Cowbird ${ }^{\mathrm{s}}$, Brown-headed Nuthatch, Brown Thrasher ${ }^{\mathrm{f}}$, Carolina Chickadee, Carolina Wren, Chipping Sparrows ${ }^{\mathrm{s}}$, Common Grackles, Common Yellowthroat', Downy Woodpecker, Eastern Towhee, European Starlings, Gray Catbird ${ }^{\mathrm{s}}$, House Finch $^{\mathrm{s}}$, Louisiana Waterthrush ${ }^{\mathrm{s}}$, Mourning Doves, Northern Cardinal, Northern Mockingbird $^{\mathrm{f}}$, Northern Parulas, Pine Warblers, Red-bellied Woodpecker, Ruby-crowned Kinglet, Ruby-throated Hummingbird ${ }^{\mathrm{s}}$, Tufted Titmouse, Unknown Warbler ${ }^{\mathrm{f}}$, White-breasted Nuthatch $^{\mathrm{f}}$, White-throated Sparrow, Yellow-rumped Warbler

\section{Walnut 2 Average width: $277.4 \mathrm{~m} \quad$ Adjacent land use: HDR}

American Crow ${ }^{\mathrm{f}}$, American Goldfinch, American Robin, Belted Kingfisher ${ }^{\mathrm{s}}$, Blackpoll Warblers, Black-throated Blue Warblers, Blue Jays, Blue-gray Gnatcatchers, Blue-headed

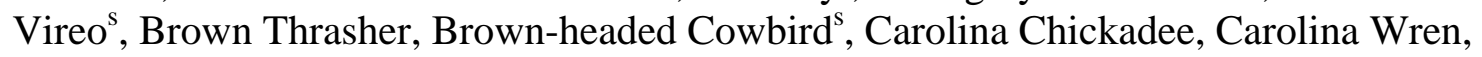
Common Grackles, Common Yellowthroat ${ }^{\mathrm{s}}$, Downy Woodpecker, Eastern Towhee ${ }^{\mathrm{s}}$, Goldencrowned Kinglet ${ }^{\mathrm{f}}$, Gray Catbird, Great Blue Heron ${ }^{\mathrm{f}}$, Hairy Woodpecker, Hooded Warbler ${ }^{\mathrm{s}}$, Louisiana Waterthrush's, Mourning Doves, Northern Cardinal, Northern Parula ${ }^{\mathrm{s}}$, Red-bellied Woodpecker, Red-eyed Vireos ${ }^{\mathrm{s}}$, Ruby-crowned Kinglet ${ }^{\mathrm{s}}$, Ruby-throated Hummingbird, 
Tufted Titmouse, White-breasted Nuthatch ${ }^{\mathrm{f}}$, White-throated Sparrow, Worm-eating Warbler ${ }^{\mathrm{s}}$, Yellow-rumped Warbler ${ }^{\mathrm{s}}$

Walnut $3 \quad$ Average width: $243.2 \mathrm{~m} \quad$ Adjacent land use: OI

American Crow ${ }^{\mathrm{f}}$, American Goldfinch, American Redstart ${ }^{\mathrm{f}}$, American Robin, Black-andwhite Warbler ${ }^{\mathrm{f}}$, Blue-gray Gnatcatcher, Blue Jay ${ }^{\mathrm{f}}$, Brown-headed Nuthatch ${ }^{\mathrm{f}}$, Brown Thrasher, Brown-headed Cowbird ${ }^{\mathrm{s}}$, Carolina Chickadee, Carolina Wren, Cedar Waxwings, Common Grackles, Common Yellowthroats', Downy Woodpecker, Eastern Kingbird ${ }^{\mathrm{s}}$, Eastern Towhee, Eastern Wood-Pewee ${ }^{\mathrm{f}}$, Fish Crow ${ }^{\mathrm{s}}$, Gray Catbird, Great Crested Flycatcher ${ }^{\mathrm{s}}$, Mallard $^{\mathrm{s}}$, Mourning Dove $\mathrm{f}$, Northern Cardinal, Northern Flicker, Northern Mockingbird $\mathrm{f}^{\mathrm{f}}$ Northern Parulas, Ovenbirds', Red-bellied Woodpecker, Red-eyed Vireo, Ruby-crowned Kinglet, Ruby-throated Hummingbird, Tufted Titmouse, White-breasted Nuthatch ${ }^{\mathrm{f}}$, Whiteeyed Vireo ${ }^{\mathrm{s}}$, White-throated Sparrow, Yellow-bellied Sapsucker ${ }^{\mathrm{f}}$, Yellow-breasted Chat ${ }^{\mathrm{s}}$, Yellow-rumped Warbler ${ }^{\mathrm{s}}$

White Oak 1 Average width: $107.3 \mathrm{~m} \quad$ Adjacent land use: LDR American Goldfinch, American Robin, Belted Kingfisher's, Blue Jay ${ }^{\mathrm{s}}$, Blue-gray Gnatcatchers, Brown Thrashers ${ }^{\mathrm{s}}$, Brown-headed Cowbird ${ }^{\mathrm{s}}$, Carolina Chickadee, Carolina Wren, Chipping Sparrow ${ }^{\mathrm{s}}$, Common Grackle ${ }^{\mathrm{s}}$, Common Yellowthroat ${ }^{\mathrm{s}}$, Downy Woodpecker, Eastern Phoebe ${ }^{\mathrm{f}}$, Eastern Towhee ${ }^{\mathrm{s}}$, Gray Catbird ${ }^{\mathrm{s}}$, Great Crested Flycatcher ${ }^{\mathrm{s}}$, House Finch ${ }^{\mathrm{s}}$, Mourning Doves, Northern Cardinal, Northern Flickers, Northern Parulas, Pine Warbler ${ }^{\mathrm{s}}$, Red-bellied Woodpecker, Red-eyed Vireos, Red-shouldered Hawk ${ }^{\mathrm{s}}$, Ruby-crowned Kinglet ${ }^{\mathrm{s}}$, Scarlet Tanagers, Tufted Titmouse, White-throated Sparrow, Wood Thrush ${ }^{\mathrm{s}}$, Yellow-rumped Warbler

\section{White Oak 2 Average width: 73.2 Adjacent land use: LDR}

American Goldfinch, American Robin, Belted Kingfisher ${ }^{\mathrm{s}}$, Blackpoll Warbler ${ }^{\mathrm{s}}$, Blackthroated Blue Warbler ${ }^{\mathrm{s}}$, Blue Jay, Blue-gray Gnatcatcher ${ }^{\mathrm{s}}$, Brown-headed Cowbird ${ }^{\mathrm{s}}$, Carolina Chickadee, Carolina Wren, Cedar Waxwings, Chipping Sparrow ${ }^{\mathrm{s}}$, Downy Woodpecker, Eastern Bluebirds , Eastern Towhee ${ }^{\mathrm{s}}$, Gray Catbirds, Great Crested Flycatcher ${ }^{\mathrm{s}}$, Hairy Woodpecker ${ }^{\mathrm{s}}$, Hermit Thrush ${ }^{\mathrm{s}}$, Hooded Warblers, House Finch ${ }^{\mathrm{s}}$, Mourning Dove ${ }^{\mathrm{s}}$, Northern Cardinal, Northern Flicker ${ }^{\mathrm{f}}$, Northern Mockingbird ${ }^{\mathrm{s}}$, Northern Parula ${ }^{\mathrm{s}}$, Prairie Warbler ${ }^{\mathrm{s}}$, Redbellied Woodpecker, Red-eyed Vireos, Ruby-crowned Kinglet, Ruby-throated Hummingbirds, Tufted Titmouse, White-breasted Nuthatch, White-eyed Vireo ${ }^{\mathrm{s}}$, Whitethroated Sparrow, Wood Thrush's, Yellow Warblers, Yellow-rumped Warbler

White Oak $3 \quad$ Average width: $102.3 \mathrm{~m} \quad$ Adjacent land use: LDR Acadian Flycatchers ${ }^{\mathrm{s}}$, American Crow ${ }^{\mathrm{f}}$, American Goldfinch, American Redstart ${ }^{\mathrm{s}}$, American Robin, Black-and-white Warbler ${ }^{\mathrm{s}}$, Blackpoll Warbler ${ }^{\mathrm{s}}$, Blue-gray Gnatcatcher ${ }^{\mathrm{s}}$, Blue Jay ${ }^{\mathrm{f}}$, Brown Thrasher ${ }^{\mathrm{s}}$, Brown-headed Cowbird ${ }^{\mathrm{s}}$, Brown-headed Nuthatch ${ }^{\mathrm{f}}$, Carolina Chickadee, Carolina Wren, Cedar Waxwing ${ }^{\mathrm{s}}$, Chipping Sparrow ${ }^{\mathrm{s}}$, Common Grackle ${ }^{\mathrm{s}}$, Downy Woodpecker, Eastern Phoebe ${ }^{\mathrm{s}}$, Eastern Towhee, Gray Catbird ${ }^{\mathrm{s}}$, Great Crested Flycatcher ${ }^{\mathrm{s}}$, Green Heron $^{\mathrm{s}}$, Hairy Woodpecker ${ }^{\mathrm{s}}$, House Finch, House Sparrow ${ }^{\mathrm{s}}$, Magnolia Warbler ${ }^{\mathrm{s}}$, Mourning Doves , Northern Cardinal, Northern Flicker ${ }^{\mathrm{f}}$, Northern Mockingbird ${ }^{\mathrm{s}}$, Northern 
Parula ${ }^{\mathrm{s}}$, Red-bellied Woodpecker, Red-eyed Vireo ${ }^{\mathrm{s}}$, Red-shouldered Hawk ${ }^{\mathrm{s}}$, Ruby-crowned Kinglet $^{\mathrm{s}}$, Scarlet Tanager ${ }^{\mathrm{s}}$, Summer Tanager ${ }^{\mathrm{s}}$, Tufted Titmouse, Unknown Warbler ${ }^{\mathrm{f}}$, Whitebreasted Nuthatch ${ }^{\mathrm{s}}$, White-throated Sparrow ${ }^{\mathrm{s}}$, Wood Thrush', Yellow-rumped Warbler

White Oak $4 \quad$ Average width: $97.9 \mathrm{~m} \quad$ Adjacent land use: OI American Goldfinch, American Robins, Blackpoll Warblers, Black-throated Blue Warblers, Blue Jay, Blue-gray Gnatcatcher ${ }^{\mathrm{s}}$, Brown Thrasher ${ }^{\mathrm{s}}$, Brown-headed Cowbird ${ }^{\mathrm{s}}$, Brown-headed Nuthatch ${ }^{\mathrm{s}}$, Carolina Chickadee, Carolina Wren, Cedar Waxwing ${ }^{\mathrm{s}}$, Chipping Sparrow, Common Yellowthroat, Eastern Bluebird, Eastern Phoebes, Eastern Towhee ${ }^{\mathrm{s}}$, Gray Catbird ${ }^{\mathrm{s}}$, Great Crested Flycatcher, Hairy Woodpecker, Hermit Thrush's, House Finch, Indigo Bunting $^{\mathrm{s}}$, Mourning Doves, Northern Cardinal, Northern Mockingbird ${ }^{\mathrm{s}}$, Northern Parula ${ }^{\mathrm{s}}$, Ovenbird ${ }^{\mathrm{s}}$, Red-bellied Woodpecker, Red-eyed Vireo ${ }^{\mathrm{s}}$, Red-shouldered Hawk ${ }^{\mathrm{f}}$, Rubycrowned Kinglet $^{\mathrm{s}}$, Ruby-throated Hummingbird ${ }^{\mathrm{s}} \quad$, Summer Tanager ${ }^{\mathrm{s}}$, Tufted Titmouse ${ }^{\mathrm{s}}$, White-breasted Nuthatch, White-throated Sparrow, Yellow Warblers , Yellow-bellied Sapsucker ${ }^{\mathrm{f}}$, Yellow-rumped Warbler

White Oak $5 \quad$ Average width: $74.4 \mathrm{~m} \quad$ Adjacent land use: LDR American $\mathrm{Crow}^{\mathrm{s}}$, American Goldfinch, American Redstart ${ }^{\mathrm{s}}$, American Robin, Black-throated Blue Warbler, Blue Jays, Blue-gray Gnatcatchers, Blue-headed Vireos, Brown-headed Cowbird $^{\mathrm{s}}$, Brown-headed Nuthatch ${ }^{\mathrm{f}}$, Carolina Chickadee, Carolina Wren, Cedar Waxwing, Chipping Sparrow ${ }^{\mathrm{s}}$, Common Grackle, Common Yellowthroat ${ }^{\mathrm{s}}$, Downy Woodpecker, Eastern Bluebird, Eastern Phoebe ${ }^{\mathrm{s}}$, Eastern Towhee ${ }^{\mathrm{s}}$, Fish Crow ${ }^{\mathrm{f}}$, Golden-crowned Kinglet ${ }^{\mathrm{f}}$, Gray Catbird ${ }^{\mathrm{s}}$, Great Crested Flycatcher ${ }^{\mathrm{s}}$, Hairy Woodpecker', House Finch ${ }^{\mathrm{s}}$, House Wren', Mourning Doves, Northern Cardinal, Northern Mockingbird, Northern Parula ${ }^{\mathrm{s}}$, Red-bellied Woodpecker, Red-eyed Vireos, Red-headed Woodpecker, ${ }^{\mathrm{s}}$, Red-shouldered Hawk ${ }^{\mathrm{f}}$, Rubycrowned Kinglet, Tufted Titmouse, White-breasted Nuthatch, White-throated Sparrow, Yellow-bellied Sapsucker ${ }^{\mathrm{f}}$, Yellow-rumped Warbler 
APPENDIX 3. End point coordinates of greenway and reference site transects in UTM meters with NAD83 datum. All points are in UTM zone 17S.

\begin{tabular}{|c|c|c|c|c|}
\hline \multirow[t]{2}{*}{ Transect } & \multicolumn{2}{|c|}{ End Point 1} & \multicolumn{2}{|c|}{ End Point 2} \\
\hline & Easting & Northing & Easting & Northing \\
\hline Alleghany 1 & 712610.29 & 3967046.05 & 712495.06 & 3967205.91 \\
\hline Alleghany 2 & 712794.66 & 3966878.78 & 712963.40 & 3966790.11 \\
\hline Beaverdam & 710179.36 & 3964972.07 & 710196.34 & 3965165.00 \\
\hline Black Creek 1 & 700080.07 & 3967042.32 & 700050.09 & 3967227.64 \\
\hline Black Creek 2 & 700132.76 & 3966584.91 & 700191.81 & 3966772.96 \\
\hline Black Creek 3 & 700030.56 & 3965706.88 & 700134.12 & 3965865.86 \\
\hline Black Creek 4 & 700330.46 & 3965298.37 & 700227.61 & 3965467.59 \\
\hline Black Creek 5 & 699808.50 & 3964984.49 & 699792.73 & 3965182.06 \\
\hline Black Creek 6 & 699762.94 & 3964422.03 & 699773.45 & 3964618.72 \\
\hline Crabtree 1 & 709184.12 & 3968794.81 & 709335.46 & 3968663.98 \\
\hline Crabtree 2 & 709654.20 & 3968412.44 & 709809.70 & 3968332.17 \\
\hline Durant 1 & 717164.50 & 3976087.63 & 717330.92 & 3975981.79 \\
\hline Durant 2 & 717507.06 & 3975682.59 & 717666.72 & 3975566.92 \\
\hline Durant 3 & 717867.07 & 3975095.04 & 717781.66 & 3975262.68 \\
\hline Falls River 1 & 718101.08 & 3976765.71 & 718292.63 & 3976755.23 \\
\hline Falls River 2 & 718501.33 & 3976766.98 & 718688.43 & 3976817.17 \\
\hline Higgins & 699076.39 & 3961304.46 & 699128.81 & 3961485.03 \\
\hline Hinshaw 1 & 701606.30 & 3959938.23 & 701570.75 & 3960126.85 \\
\hline Hinshaw 2 & 701723.41 & 3959507.68 & 701695.97 & 3959694.74 \\
\hline Hinshaw 3 & 701908.54 & 3959140.89 & 701835.11 & 3959314.81 \\
\hline Ironwood & 710975.07 & 3969758.33 & 710936.17 & 3969950.81 \\
\hline Lynn & 712090.49 & 3972002.73 & 712013.50 & 3972168.62 \\
\hline North Hills 1 & 710321.76 & 3968514.52 & 710463.89 & 3968650.92 \\
\hline North Hills 2 & 710708.08 & 3968561.07 & 710899.49 & 3968529.20 \\
\hline Oxxford Hunt & 697108.15 & 3961024.36 & 696970.64 & 3961094.37 \\
\hline Oak Park 1 & 708433.20 & 3969170.49 & 708630.31 & 3969150.91 \\
\hline Oak Park 2 & 708874.60 & 3969118.85 & 709049.22 & 3969044.90 \\
\hline Parkway & 695523.10 & 3961443.40 & 695655.39 & 3961576.48 \\
\hline Pirates Cove 1 & 702223.69 & 3959537.36 & 702273.58 & 3959726.64 \\
\hline Pirates Cove 2 & 702290.90 & 3959070.95 & 702278.53 & 3959267.25 \\
\hline Shelley & 711603.32 & 3971556.74 & 711762.92 & 3971466.49 \\
\hline Sawmill 1 & 711731.79 & 3972652.97 & 711775.05 & 3972840.30 \\
\hline Sawmill 2 & 712210.51 & 3972415.87 & 712360.63 & 3972537.34 \\
\hline Swift Creek & 700140.14 & 3956076.36 & 700005.26 & 3956213.02 \\
\hline Trafalgar & 696520.67 & 3961066.90 & 696677.22 & 3960945.39 \\
\hline Tarbert 1 & 697635.45 & 3959565.04 & 697562.73 & 3959742.53 \\
\hline Tarbert 2 & 697865.25 & 3959255.47 & 697725.88 & 3959395.20 \\
\hline
\end{tabular}




\begin{tabular}{lcccc}
\hline \multicolumn{1}{c}{ APPENDIX 3. } & Continued. \\
\hline \multicolumn{1}{c}{ Transect } & \multicolumn{3}{c}{ End Point 1 } & \multicolumn{2}{c}{ End Point 2 } \\
\hline & Easting & Northing & Easting & Northing \\
\cline { 2 - 5 } Umstead 1 & 702931.42 & 3970643.05 & 702939.80 & 3970831.47 \\
Umstead 2 & 702437.41 & 3968888.53 & 702503.50 & 3969070.83 \\
Umstead 3 & 702725.59 & 3968990.11 & 702905.02 & 3968922.96 \\
Weston 1 & 699331.35 & 3967013.75 & 699247.32 & 3967193.37 \\
Weston 2 & 698713.59 & 3966722.87 & 698891.66 & 3966770.18 \\
Walnut Creek 1 & 707693.87 & 3959940.39 & 707880.15 & 3959876.60 \\
Walnut Creek 2 & 708121.94 & 3959984.30 & 708246.24 & 3960129.32 \\
Walnut Creek 3 & 708561.33 & 3960417.35 & 708588.73 & 3960594.78 \\
White Oak 1 & 692378.14 & 3961591.87 & 692562.35 & 3961516.07 \\
White Oak 2 & 692926.13 & 3961394.10 & 693126.01 & 3961397.07 \\
White Oak 3 & 693500.37 & 3961214.12 & 693665.11 & 3961114.60 \\
White Oak 4 & 694236.14 & 3961252.47 & 694406.73 & 3961231.89 \\
White Oak 5 & 694256.14 & 3960349.80 & 694163.78 & 3960512.45 \\
\hline
\end{tabular}

